University of Louisville

ThinkIR: The University of Louisville's Institutional Repository

8-1947

\title{
Enriching the fifth grade unit, "The Ohio Valley," by excursions in the city of Louisville.
}

Frances P. Moore

University of Louisville

Follow this and additional works at: https://ir.library.louisville.edu/etd

Part of the Education Commons

\section{Recommended Citation}

Moore, Frances P., "Enriching the fifth grade unit, "The Ohio Valley," by excursions in the city of Louisville." (1947). Electronic Theses and Dissertations. Paper 2014.

https://doi.org/10.18297/etd/2014

This Master's Thesis is brought to you for free and open access by ThinkIR: The University of Louisville's Institutional Repository. It has been accepted for inclusion in Electronic Theses and Dissertations by an authorized administrator of ThinkIR: The University of Louisville's Institutional Repository. This title appears here courtesy of the author, who has retained all other copyrights. For more information, please contact thinkir@louisville.edu. 


\title{
UNIVERSITY OF LOUISVILLE
}

ENRICHIMG THE FIFTH GRADE UITT, "THE OHIO VALCEY," BY BXCURSIONS IN THE CITY OF LOUISVILLE

\author{
A Diseertation \\ Subat tted to the Faculty \\ of the Graduate School of the Univerelty of Louideville \\ In Partial Nulfiliment of the \\ Requirements for the Degree \\ of haster of Arts
}

Department of Bucution

Frences P. Moore

Year

1947 
This PDF document is a scanned copy of a paper manuscript housed in the University of Louisville (UofL) Libraries. The quality of this reproduction is greatly dependent upon the condition of the original paper copy. Indistinct print and poor quality illustrations are a direct reflection of the quality of materials that are available for scanning. The UofL Libraries greatly appreciates any better copies that can be made available for replacement scans. 
NAME OF STUDENT:

Frances P. Moore

TITLE OF THESIS: WRICHNG THE ELENH GRADE

UNIT, "THF OHTO VALLEY"

BX ExcuRSIONS IN THE CTTY

OF LOUTSWWHE

APPROVED BY READING COAITTEE COAPOSED OF THE FOLLOWING MPBERS:

Noble H. Kelley

C. A. Rubado

NAME OF DIRECTOR: J. J. Oppenheimer

DATE: AUGUST 27,1947 
ENRICHING THE FIFTH GRADE UNIT, "THE OHIO VALلWE," BY EXCURSIONS IN THE CITY OF LOUISVILLE 


\section{TABLE OF CONTENTS}

CHAPTEK

PAGE

I THE PROBLEM AND YATERIALS AND HETHODS USED

1

IN SOLVING IT

II BRIEF HISTOFY OF THE EXCURSION MOVEWENI

5

III REVIEW CF THE LTTERATUTE

IV SOURCES IN LOUISVIULE FOT. EXCUTSIONS IN

62 RULATION TO THE UNIT, "THE OHIO VALLEY"

$V$ THE ADUINISTRATION OF A CLASS EXCURSION 121

VI SUMAAY AND CONCLUSIONS $\quad 167$

$\begin{array}{ll}\text { BIBLIOGEAPHY } & 171\end{array}$

$\begin{array}{ll}\text { THE APPEMDIX } & 177\end{array}$ 
CHAPTER I

THE PROBLE AND MATERIALS AND METHODS USED IN SOLVING IT 
THE PROBLEM AND MATERTALS AND METHODS USED IN SOLVING IT

\section{Introduction}

In January, 1947, the social studies unit, "The Ohio Valley (The Middle States)," was distributed to all Louisville Elementary Schools to be accessible to the fifth grade teachers. This unit, prepared and written by the Division of Curriculum and Research under Dr. John Doteon, w11 be described in greater dotall in Chapter IV of this study.

AB a teacher in the Louleville mementary Schoole for the last seven years, with experience in the Ilfth grade the past five, the writer has felt a need for class excursione to clarify the thinking of the flfth grade pupils and to enrich the curriculum by such first-band experiences.

In teaching, eopecially with a large class, many ways must be devised and several activities undertaken to stimulate the interest and meet the needs of so many varied personalities. Such was the altuation on the writer's part in teaching the unit, "The Ohlo Valley," wth forty-eight students during the second semester of 1947. In the group's planning for the study of the unit several suggestions and activities were listed. One of which was the suggestion to make class visits to places in their own city as Louisville was a part of the Ohio Valley. Furthered by this intereat and in the matter of selection of resources to viait, the writer became interested in the possibilities and the use 
of excureions in the teaching of the unit.

\section{The Problem}

Statement of the problem. This study is therefore concerned with the following:

A. What are the avaliable sources of information in Loulsville that may be viaited by fifth grade students in connection with their study of the unit, "The Ohio valleys"

B. Which of the places avallable would the Loulaville flfth grade teachers select as giving a better understanding of the urit mentioned above?

C. Of the sources available for visitation what are their instructional values, their limitations, and their requirements or conditions on which they be visited?

D. What are some of the best methods of procedure in the administration of a class excursion?

Limitation of the problen. This study is limited to short trips, that required the range of a few minutes time but not more than achool day, for fifth grade pupils only.

III Materials and Methods Used in the Study

In an attempt to anower the above, the results and the findinge of the following $w 11$ be analyzed:

(1) A questionnaire sent to thirty-five fifth grade teachers.

(2) Interviews with ten teachers of the fifth grade 
who had used excursions in their teaching.

(3) Interviews wth Dr. John Dotson, the Director, and wth the comatitee of the Diviaion of Curriculum and Research who wrote the unit.

IV Contents of the Chapters to Follow

As a background for this study, a brief history of the excursion movement will be presented in the chapter to fol10w. This includes not only the very early beginnings of excursions in sowe foreign countriee, but also a brief history of the excursion movement in the United States. The review of the Iiterature in Chapter III describes the kinds of excursions, their values and limitations, and a brief deacription of other studies and investigations made of their use and value.

All of the available sources of information in Loulsville for providing better understanding of the unit, "The Ohio Vailey," will be described in chapter IV. Their requirenents or necessary arrangements needed for visiting will also be presented.

From the literature read and from interviews with fifth grade teachers, a method of procedure -- the preparation, the excursion, and the follow-up-for an excursion is described in Chapter $V$. An actual trip taken by a fifth grade class studying the unit, "The Ohio Valley," will be given as an example. 
Any conclustions or recomendations as found by the writer will be summarized in the last chapter.

As far as the writer has been able to determine, no study of this type has ever been made in the Loulsville Public Schools. Olga Schmutz in her thesis, A Survey 오 the Audio-V1gual A1de Being Uaed by the Louisvi11e white Fourth, Fifth, and Sixth Grade Teachere, described briefly the advantages and $11 \mathrm{mitations}$ of the school journey and the extent of its use by the intermediate grade teachers. Her thesis did not include a study of what sources were avallable and their value, nor of the beet procedure in administering a class trip as is the purpose of this study. 


\section{CHAPTER II}

BRIEF HISTORY OF THE EXCURSIOA MOVEMET 


\section{BRIEF HISTOFY OF THE EXCURSIOA YOVEMENT}

\section{Early Beglnaings of Excursions}

Excursions are not modem dovelopment by any mean, as practices akin to them are found in earlier periods. 1 Kendel atates, EHIstorienlly the school excursion may be cannected wth the wandering and begging studente of the Uidal Ages. The distinct edueational value of travel was recogenized by nost of the witters on education of the alxteenth and serenteenth outurice.... Atyoo gives this Interesting account of the eariy use of excuralons.

"Prior to any common use of written langunge, an excureion was prectically the sole method of acquiring information concerning natters beyond the confines of an individuel's ow Iinited anvironment, or, falling thet, an opportunity to 11 aten to reports from persons who had made excuratons. We may be cllowed to thini of the Homerie barde and of the wadering winetrele of the Hidale Ages as oxcursioniste on the grand seale who brought to the peoples amone whom they mandered a knowledge of renote pleces and men and ideas. Lang before the age of Perieles, well-to-do Groeks were traveling to ecoure information. Oniy by meane of extended travele -- in kaypt and other castern Iands - ald Herodutus ver-1fy hoaroay and obtain the mes of information Ineluded in his history. Ana, eenturies later, when the Imagination of a Lareo Polo or a Columbus wa ceptured by tales of returned travelers, woh men could go to no library..... but wust set forth theneelves to try to reach

\section{1}

Paul Monroe, (editor), "School Exaursione," (I. L. Kandel), A Gralopedis of Eduestion, Hew York: The Macmilian Company, 1911, II, 542. 
the lands that stirred their interest."2

This period of travel, however, preceded the education of the school and not intimately connected with it. In the course of time a sojourn away from home came to be regarded important and almost essential to the completion of an education. We read of Greek and Roman youths traveling to Athens, Alexandria, Rhodes, or other Intellectual centers of the ancient world.

The importance of auch journeys is explained by Atyeo. "Experience so obtained have ever since [from the time of the ancient journeys] been highly regarded from an educationel standpoint, nor has such regard been limited to the purely cultural values of such diversified contacta. Witness to the recognized practical value of first-hand knowledge is found in the medieval practice conom among the young jourmeymen who, on completion of their apprenticeships, set out to exercise their callings in many different regione - usuelly of their own countries -- and thus gain extended experience before settling down to carry on their trades in some particular locellty. These years of travel were the wanderjahre of the German woriman. Equally, as a matter of course, the young French workingman made his 'tour de Frence before returning to his native locallty to establish himself. This practice sa in a manner the working class equivalent to the acquisition of a trade skill of the 'Grand Tour' of the continent, and in particular, of Italy, which, eepecially from the period of the Renalssance, came to be looked upon as an essential to the educati on of the 'gentleman'. Both the continental tour of the young patricians and the wander years of the young workingmen point to

2

Henry C. Atyeo, The Excurion as a Teaching Technioue, New York: Bureau of Publlcations, Teachers College, Columbia University, 1939, pp. 1-2. 
the comocon agreement regarding the worth of first-hand knowledge -- In the case of the wellto-do a a purely cultural asset, and in the case of the workingman as an important vocational asset."3

Both Aristotle and Socretes used the trip methode in their teachings. The Greek peripatetics furnish a striking example of teacher and pupils going directly to the natural situation for first-hand knowledge. "In that age it was a common oight in Athens and the environs to see the venerable Socrates and his disciples here and there in the practice of observation, discuseion, and mediation."

Walks and long journeys of explorations were taken by the pupils in the school of Vittoring da Feltre during the flrst part of the fifteenth century.

In the seventeenth century Comenius strongly recommended the excursion procedure in his pronouncement that people mat be taught to get their knowledge, as far as possible, not from books but from the earth and sky.

The excursion as a type of activity bodying the basic ideas of reality in ecucation is illustrated by Rouscenu who considered it as a chief method in Emile's education. "Baile was to learn hls place in nature and in

\footnotetext{
3

Intale, p. 2 .

4

Charles F. Hoban, Charles F. Hoban Jr., and Semuel B. Zi man, Yieualiring the cimpleulum, Hew York: The Cordon Company, 1937, p. 30 .
} 
eoclety by moving from place to place, and enguging in immediate contact with the objects in his environment. The Ldeas of Rousseau, as is well knom, are basic to the contemporary progressive ecucation wovement. "

On a anall seale Peatalozzl, in his celebrated school at rverdun, used school journoys. These trips were enjoyable but wore loosely orgenlzed and thus lecked educational value. Froebel also made his contribution to the excureton movenent.

Late in the nineteenth eontury Francis Parker Introduced the school journey in bis school at Chicago. Lann, Barnard, Sheldon, Parker, and Dewey, who have helped to break down artifleiality, isolation, and pretense in education in our country, have paved the way for the use of excuraions and their possibilities in the modern elementary school.

"Although there 18 evidence of apemodle use of chool Journey practice from as early as the Greoks, its first eystematic organtzation as an approved school activity is recorded in the present century."

\footnotetext{
5

David Weavor. "Excureions in a Metropolitan Center," Thirteanth Yearbook of the Departinent of Blementary Prinalpale, P. 285. Washingtion, D. C. I Hational Bducational AleoClation, 1934.

6

Charles Hoban, Charles Hoban Jr., and Samuel Z1aman, see stte, p. 30 .
} 
An account of the wore recent uses of excursions will be reserved for the next two sectione of this chapter. This brief historical aketch of early days is to point out that the idea of firat-hand contacts with the real things of Iffe is not new to education. From early times there has been a continuous stream of major and minor prophets of the need for reallty and genuine experience in school life.

Origine and Use of the School Excursion in Some Forelgn Countries

The causes underlying the development of the excursion method have not been the same in every country, nor are the ends which the excursion serve identical everywhere. Variations in 1 ts conduct and use are closely related to the national educational policies and polltical philosophies. A brief historical study of the influences that have led to the inereasing use, and an examination of the present manner of 1 te organization may serve as an indication of the values inherent in the excursion as an instructional method.

Nearly all of the continental buropean countries and Japan have made their experiments with the educational excursion, but Inampuch as Germany and England lead all the others, both in the extent to which they use it as a teaching method and in the development of means of encouraging 1 , these two countries will be considered first. 
This information for the most part derived from Atyeo's dissertation is about excureions prior to World War II.

The School Excursion in Germany

The beginninge of the excurgion. It is in Gernany that the school excursion has been more frequently used than in any other land. It has won recognition there as an acceptable metrod of instruction and has become definitely established part of the school program. The initial impulse to the employment of the excursion seems to have been received from the Germen Youth Hovement.

"This Youth Moverent wich originated in the late nineties, was in part the outcome of a reaction against the traditional education with its emphasis upon the training of the intellect and its neglect of the enotional needs and interests of the adolescent pupil. Rebellion against the imposed restraints and conventions, the 'back-to-the-land' urge in search of freedom, the demand for first-hand experience and knowlodge to supplement the dry-as-dust discipline of the classroom, and the desire to set up chosen standards rather than blindly accept those imposed by authority all these, and more, played tileir part in the inception of the Youth Movewent and its owft conquest of the country ...." "The young wandervogel, as the members of the group called themelves, filled with love of country and of all for which it stood, were stirred by the senge that the village festivals, folk songs, folk dances, or works of native art that they learned to know were a part of their own heritage, and they lent every effort to preserve them."?

Atyeo, op. c1t., pp. 8-10. 
This Youth Movement stimulated the use of the excursion as a wethod of instruction. "Leaders in the educational field jolned in the various activities of the youth programs and cepitalized the opportunity to give the excursion an educational as well as a recreational purpose."

Under Professor Rein of Jena University excursions had been made a definite part of the German educational program In the nineteenth century, but the founding of the Wandervögel strengthened the movement.

These early excuralons consisted of long, elaborate, and strenuous preparation, the journey fatiguing, and the daily Itinerary also exhausting. These were directed inly to character bullaing.

Some of the German leaders of these early times, who were experimenting with an excurgion technique, were Salzmann, Bender, and Story.

Bender as interested in excursions in connection with class work as character-building opportunities. Story's excursions were aimed at increasing puplls' knowledge of thelr eurroundings. He also used the excurai on as a means of instruction for the teachers training in the seminary. Atyeo points out the reaults of this training.

Hot only aid the prospective teachers thus have an opportunity to become scquainted with the possibilities of the excursion, but they

Ibid. p. 13. 
were given instruction in developing a technique which opread throughout Gerwany as these young teeckers secured positions. The influences of Story's excursions, however, extended far beyond the boundaries of Germany." 9

Other German educational leaders and teachers have contributed directly to the development of the excursion method.

Ziller of the University of Leipsic considered the excursian to its value for comradeship between teacherpup1I, also as a charecter building agency, and an intellectual exercise.

Between 1900 and the end of world War I little change took place in the use of excursions except in the gradual increase and variety.

"The excuraion as an instructional method probably attained its greateat development during the Republic...." when Hitler took power trips were taken on Saturday by the Hitler Youth groups largely for physical exercise rather than for instruction. Excursions were used to promote an understanding of German history and culture as well as develop loyalty to the atate.

Ibid. p. 17.

10

Ibid. p. 19.

11

Loㅗ. 소. 
Troen of excurgions. Bxcursions in Germany may be divided into three classes -- those purely for recreation, those for physical development and exercise, and those for instruction. The first is similar to our school pienics for social and pleasant recreation. The second was so common after World War I when so many children were found physically to be below normal. The class instmuction trips, the most important type, was made in connection with the study of some special topic the class was studying. These walks to objects of local interest were knom as "teaching welks." On these trips Gersan culture was brought to the attention of the students.

The excursion technioue. Excursions usually undertaken by the regular classrow teacher also were conducted by teachers of special subjects. As participation was compulsory, funds were provided to meet necessary costs of transportation. However, most of the excursions objectives are within walking distance. The frequency of excursions in the school progras depends upon local conditions and regulations, and the interest of the teachers. The number ranges from weekly trips to a mere three or four in year. In planning trip the teacher usually makes the selection and plans the dotalls of the trip. However, pupils make suggestions and sometime much of the preparation is their reaponsibility. 
It has been found preferable for teachers rether then guides to make the explanation of interesting points at the places visited. This necessitates that the teacher mat make the trip previously with a well informed guide or take museum Instructional courses offered for teachers in many cities.

buring the trips notes are taken to be placed in a class notebook on the group's return. Special topics for reports, often assigned to individual pupils or small groups, are presented later in class.

Longer tripe are becoming increasingly popular in Gerwany especially with the development of the network of hostels.

An unexpected outcome of the excursion method has been the developwent of interest in the establishment of local museums.

As may be sumarlzed the excursion program in Germany has been to promote physical welfare and widen the knowledge and devotion to the Fatherland on the part of the boys and girls.

The School Excursion in England

It was in England that the school journey first placed on an organized, oystematic plane. "In 1905 school journeys recelved official sanction in England, and in 1908 the London County Council made subsidy provisions for them 
in the school code. 12

The beginnings of the excursion. "The school excursion in England seers to have grown from the initiative of individual teachers. The first excursions were designed to provide social experiences for pupils in the elementary grades, but they have in the course of time developed into what the London Education gystem has termed 'an extramural aystem of education." 13

The use of the excursion has never been made obligatory in the school system. Whether trips are made or are not depends upon the local school programs and on the attitude of the teacher, but all types of schools do make use of the excursion.

The School Journey Association was forsed in 1911 in recognition of the value of class excursions. It has undertaken to secure financial backing for excursions, to obtain autable insurance for the schools or Individuals responsible for their management, and to provide information. This association has grown rapidiy.

Closely allied to the above association the English Secondary School Travel Trust is a voluntary non-profit or-

12

Charles Hoban, Charles Hoban, Jr., and Samuel Ziaman, op. cit., p. 30 .

13

Atyeo, ope cit., p. 27. 
ganization wich makes foreign travel possible for schools. Trpes of excurgions. The English excursions may be grouped under four heads. The first, the "junior school journey," is the usual kind in the elementary schools. This consists of visits to municipal buildings, or other places of local interest or beauty. The object of these excursians is to provide information and to give pupils an opportunity for social contact. The second type, known as the "walking journey," is sibilar to the recreational or physical exercise excursion of Germany as described above. These shorter trips must be approved by the School Board Inspector and be made during school hours. The other two types of excursion, of which this study is not concerned, diay be mentioned here. They are the "homeland journey" and the "continental journey" for secondary students. For all of these trips to be within the reach of every gtudent is one of the aims of the school Journey Association.

The excursion technioue. "It is rather difflcult to make any generalizationsabout the excursion as wethod of instruction in England because its handing is left to individual Initiative and therefore present many local variations." 14

The planning is usually made by the teacher and clasa

14

Ibid., pp. 30-31. 
to bring further light upon a subject alresdy considered, or to gather information about problem yet to be solved. Notes are taken during the trip and a complete record is made upon return.

Comparison of the German and English Excursions

The German and Inglish excursions differ in their purpose, organization, and frequency. In Germany the purpose of the excursion is to develop an appreciation of the Gerwan people and culture and to make all students loyal to their Fatherland. The English regard the excursion as primarily a social activity or as an opportunity for developing fine characteristics of a "gentleman" rather than as an organized trip with an instructionel aim. This is in accord with the British viewpoint that culture is acquired fundamentally through friendly contacts, wide experience, and knowledge.

"In Germany the exclirsion is a basic method of instruction, the center of a topic; in Fingland the excursion is for the most part employed to supplement the regular work of the class. The English excursion lacks the detailed and regiirental character of the German plan, is more of the nature of a social visit to an educationalIy interesting place." 15

The increase in the use of the excursions has been furthered by such national organtzations as the School Journey Association in Figland and The Youth Hostel Association in Germany. The former was forwed after the number of ex-

\section{5 \\ Ibid., p. 32.}


cursions undertaken created a need for such organization. It was organized with the direct aim of encouraging for cultural ends botr. local and extended jourieys. Tho Hostel Association was formed as a recreational organization prior to the extensive use of the educational excursion and it cooperates with schools by permitting the use of its accomodations.

In both countries the use of the excursion has been approved and encouraged by the ministries of education with significant differences in method.

"In Germany the encouragenent has been given by ministerial decrees and suggestions which have ade the excursion in certain respects practically compulaory. Wandertage has been definitely recomended and required as a part of the school prograu. Such is not the case in England, where, except for the coordination achleved through the national organization, the excursion is left to local initiative. Some counties and especially large cities, use it extensively; in other districts it is almost unknown. "16

The Excursion in Other European Countries and Japan Little information 18 avallable regarding the use of the excursion except in Fngland and Germany. However, it may be that in some countries the excursion may be used wore frequently than is evident from the literature available. Again frow Atyeo a few facts about the character and the ends to which the excursion has been directed in some Buropean countries, prior to World war II, will be briefly presented.

16

Ibid., p. 33. 
Austria. Austria has empesized the use of the excursion as alrect method of teaching through which children may learn from observation. Probably no other European country, with the exception of Gerwany, has emphasized its value wore strongly. The whole Austrian excursion program follows very closely the German plan.

Erence. Little information 1 avallable regarding the extent to which the excursion wethod is used in France. Excursions rarely mentioned in achool literature, and there seems to be no national effort to further 1ta use. School excursions organized by individual schools or teachers are usually an extra-curricular activity. Freedom is given to teachers to plan work according to thelr own ideas. Horn adds this information "In France, and especially in Paris, visits to industrial districts are encouraged."

Italy. Excursions are taken as extra-curricular rather than as a mothod of class instruction.

Russia. "In Russia, The Young Commint Party is the center of the youth moverient. Through it excursions to some of the great factories are organized to acquaint the young wen and women wth the industrial program of

\footnotetext{
17

Ibide, p. 33.

18

Ernest Horn, Methods of Instruction in the Social Studies, New York: Charles Scribner's Sons, 1937, p. 405.
} 
Fussia, and journey are arranged to visit and study the large cooperative farms. The historical museums are also popular objectives for excursions, in particular the Historical unseum in Moscow." 19

However comparatively fow long trips are made and the excursion is not used extensively by the schools.

"The school excursion has wade 1ts way in Fussia to the extent of winning recognition as an educational method in teacher-training institutions." 20

Poland. The government has been interested in excursions essentially in connection with the teaching of civics. From the beginning emphasis has been on the human response and activities in the situation observed as well as upon bare facts of geography or other sciences.

Bulgaria. The Ministry of Education has encouraged excursions for the elementary schools.

The excursion has been used to some extent in other European countries such as Belgfum and Holland.

Scandinavian countrieg. "Sweden makes participation in a state number of excursions a condition of graduation

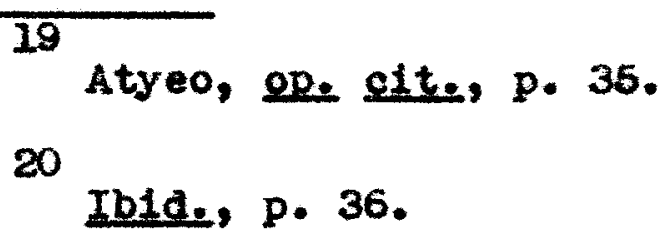


from the elementary schools." 21

With approximately sixty thousand Swedish children traveling each year, the Swedish railrosds arrange special tours of the mountain regions. Finland has provided a state comission charged with the sole duty of attending to school journeys.

Japan. The Japanese oriental reverence for antiquity and tradition is the reason for their use of the excursion to create an interest in the literature and religion of "Old Japan."

"All Japanese school children go on excuralons particularly during the last two years of the elementary achool and during the high school years. Occasionally, both boys and girls are to be found in the aame group, but usually the groups are separate."23

As might be summarized the excursion in Japan are the weans of providing first-hand experiences in order that boys and girls may learn to appreciate and love their country to the utmost.

summary. Germany and England have been the leadera in the use of the educational excursion. Encouragement of their use has been made by associations and the educetional

21

Ibid., p. 175.

22

Horn, ope elte, p. 405.

23

Atyeo, ope cit., p. 39. 
mintstries.

In most of the European countries and in Japan the excursion method is handled as to fit into the national education pattern and to contribute to the fulfilment of the national aim.

Hecent Development and Present Use of the Excursion Method in the United StateB

Charles and Frank Mcisurry influenced by the teachinge of Herbart, advocated the use of excursions in the teaching of geography as well as of science in the United States at the latter part of the nineteenth century. Francis Parker introduced the school journey in his school at Chicago in the latter part of the ceritury.

In spite of the theoretical acceptance of the excursion method in the United States, progress in its appiication has been slow here in comparison with that in some countries. What accounts for the tardy development of the school trip in the United States?

Reasons for the Tardy Development of the Excursion Movement in the United States

Several factors may be singled out to which such relatively slow acceptance is attributable.

In Anerica the schools from pioneer days have placed great emphasis upon literacy, and the learning and mastery 
of the "Three $R^{\prime} s$ " through books and other indirect meano in the classroom, rather than upon direct experience beyond the walls of the school.

In those early days little tine was spent in the schoolroom and there was no time for excursions. The puplis had their direct experience in helping to provide the dally bread and other family easentials.

In apite of the increase urbanization of our country and the complexity of our society, the school, except in very few instarices, is otill placing greater emphasis upon indirect learning by means of instructional tools provided in the classroon. Few schools are realizing and utilizing the potentialities of direct experience trips to available resources.

\footnotetext{
Among the causes retarding the imisediate and general acceptance of the excursion among other recognized teaching techniques in the United States were the facts that wany of the needs which it weets were already in part provided for through the kind and conditions of 11 fe in this country, ard through alresdy existing organizations or clubs...."24
}

Here in the United States the needs for freedom and for activity have been met through means other than the school excursion. The school day is short enough to permit ample time for physical exercise and play. With the multiplicity of Interests hich appeal during out-of-school

\footnotetext{
24

Ibid., p. 176.
} 
hours, there is weelth of experience which f1lls the pupilg' time completely. Some might claim that the day is already so filled that only by substituting a more worthwhile progran can any new activity be introduced. It is not a question of adding to, but integrating or weaving the excursion into the present school program. Many American homes hold rore varied opportunities of informed education worth than are possessed by homes of corresponding level in other countries. Sumer trips are often taken by many American famllies. Children of less privileged families often find partial compensation for their insufflclent home life in parks and libraries.

Another clue to the lowness of adoption of the excursion wethod in the United States is to be found in the fact that the majority of teachers have had no personal familiarity with it, efther in their own early school experience or in their professional training. Emphasis have been placed upon toaching wethods and only in the past few years have excursions been given consideration in the training achools for teachers.

"In European countries opportunity for the theoretical exanination and practical application of the excursion technique is provided in the pedogogical seminaries. It is probable that until the educational excursi on takes rark with other methods of instruction in American norral school and college education courses, there is likely to be found persisting among the teachers in the United States a tendency to regard it as a oomewhat radical and perhaps un- 
necessarily troublesome means of instruction."25 Numerous and varied teaching methods eraployed in our schools include some witich are closely allied with the excursion procedure and have done duty in its stead. Visual aids as illustrations in textbooks, plctures on bulletin boards, and motion plctures are illustrative of such substitute service. These various means have brought the outside world into the classroom so much as to ke excursions seen less essential.

Frequently, the amount of red tape connected with the arrangemente to be wade is so great that many teaclers, who have been unable to arrange for the excursions easily or to take them during school hours, have felt that they did not repay the effort expended. In connections with this there might be added this reason why excursions have not been further developed. Our mania for organization and systen, our worskip of "business-like efficiency" of inflexible schedules, recitations, and other formalized routine would suffer if longer and less regular periods necessary for trips were arranged. "After-school, evening, Saturday trips are often scheduled and conducted, but for obvious reasons they are usually not so effective as those taken 
on regular school time. ${ }^{26}$

Another hindrance encountered by the excursion method lies in the unwillingness of many teachers to assume responsiblitty for pupils safety. Even when provided with the authorization of the school authorities, with wivers from parents, and with liability insurance, sowe teachers feel unwlling to riak the possibility of accident. It wight be said here that in foreign countries places chosen may be reached easily by afoot and consequently dangere appear to be less. Too few places my be reached by foot in metropolitan areas in our country. Mckown and Roberts point out that fuerican education has always been "Bchoolhouse bound." To the average Individual "education" has always meant a mosaic of very definite and formal elements such as school buildings and grounds, classes, assigneents, recitation, punctuality, and the like making a systematized school day from Monday to Friday. The school came to be considered not one, but "the" educational institution of the comounity. To the average adult the away-from-the-schoolhouse activities are considered cheaper, less dignified, and less educative,

\section{6}

Harry C. McKown and Alvin B. Roberts, AudieVisual Alde to Instruction, New York: McGraw-Hill Book Co., Inc., 1940, p. 184 .

27

Ibid., p. 182 . 
than those inside 1t. Even today when such an individual sees a group he usually takes this attitude, "what are these kids doing here, why aren't they in school?" Such restricted conception has handicapped education.

In spite of the many years of experience on the part of European countries, our American educators have been tardy in recognizing the innate instructional possibilities of excursiona, and therefore did not provide the leadership necessary to a wholesome development of it. The following explanation has been offered for this delay. Perhaps our educators were too busy with other problems, or had relatively few opportunities to learn about excursions, perhaps they too felt that the child is educated in schoolhouse. However, the American educator is amed at the extent to which the instruction is carried on outside of the school plant in wany foreign countries.

Influences Affecting the Movement in the United States The adoption of the excursion 1dea in this country was hastened through the Influence of American students who had received their training abroad, such as, Van Liew and a few others who brought back from their continental study profound enthusiasm for excursions and bent every effort to extend its use here in America.

28

Ibid., p. 183. 
Other influences are facilltating the development of the school trip in American schoole. Makown and 29

Roberts lists the following: a broadened outlook on the part of parents and professional educators, a sincere desire to capitallze all of the instruction materials and devices available, the hearty cooperation of officials of visitation points or objectives, and an appreciation and recognition of possibilities of school trips.

\section{Barly Recognition of Exeursions}

One of the first city school systems to give official recognition to the excursion as a mothod of instruction was that of Philadelphia. There a comittee of fifty studied the excursions made and reconmended binilar methods of procedures as will be discussed in Chapter $V$ of this study.

The endorsement of the excursion method by the Pennaylvania State Education Department was brought about by the enthusiasm of C.P. Hoban who has done noteworthy ploneer work in vieuel education. Mr. Hoben, who belleves that the ochool journey is one of the most important and valuable of all vienal aids, has written pore articles on different aspects of the excursion than any other single writer.

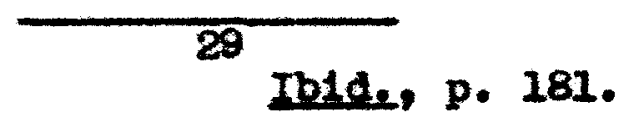


Wational recognition was given to the excursion technique in 1931, at a conference of the Association of Childhood Education." ${ }^{30}$ This conference not only brought the excursion into focus of national attention but suggested way and weans which it might be evaluated and studied.

Literature as an Index of the Use of tire Excursion An increase in ifterature is $\mathrm{s}$ an index to an increase in its use. The varying amounts of current litereture that appears from one period to another way be considered an index of the trend of increase in interest and use of the school excursion.

Up to 1920 mention of the excuraions in educational writings in this country apart from the references of Van Liew and a few others sas scanty.

However, the trend from then [1920] forward is toward deciding increase in the number of articles appearing. For the five year period, 1920-1924, only four articles appeared; during the interval, 1925-1929, the number rose up to nineteen; while from 1930-19,34 the articles reached fortyfive; and from the period 1935-1939, one hundred eighty-five

Atyeo, 2p., eit., p. 47. 
articles appeared."

\section{Variations in Practice}

The school excursion as carried out in the United States at the present time exhibits a wide variation of practice, ranging all the from the occasional informal trips initiated by the individual teacher to those well organized excursions that constitute a part of a school program. The wost elaborate excursion programs are to be found in the progressive and experimental schools. Because of their small classes, their especially equipped teaching personnel, the flexibility of their school program, and their adequate financial rescurces, these schools are able to experiment with the excursion procedure.

However, the present use of excursions is not confined to experimental and private schools. In the literature many articles refer to individual school or city "excursion programs."

Some of the types of excursions as employed in England and Germany have been adopted with modification here In the United States.

The "teaching walks" In Germany or the "junior-school

31

Ella C. Clark, "An Experimental Evaluation of the School Excursion," Jourpal of Ecperimental Education, 12:10, September, 1943. 
journey" in England finds its counterpert in the informal extra-curricular excursions of vartoue achool cluis. The Gerwan "Instructional excursion" and the English "educational visit" is the echool excursion as discussed in tilis study. 
CHAPTER III

REVIEW OF THE LTTERATURE 


\section{REVIEW OF THE LITERATURE}

\section{The Importance of Ervironment}

The educative importance of the environment has been under estim ted. In the past 1 ts influence has been minimized because major emphasis had been placed on passive learning through listening and reading. When it is recognized that learning is fundamentally an active process in which the child explores, manipulates, utilizes, and adjusts hisaself to the physical and social forces and factors which surround him, the environment assumes an important place. Environment is all-important as it 18 the only avenue through which we can influence the growth of children. We are unable to reach into their nervous eystems and wake direct conriections as in telephone exchange. Therefore we are forced to work indirectly by providing conditions which will call out, exercise, and reward the habits, attitudes, skills, and ideals which we wish to develop. It is the environment and their use of it that determines what the children will experience each day and hes a pert in determining what they will become. Children growing up in a narrow environment are hampered in their physical, social, aesthetic, and even

\footnotetext{
1

John A. Hockett and E. W. Jacobsen, Modern Prectices
} in the Elementery School, Boston: Ginn and Company, 1938, p. 124 . 
intellectual development. They never realize the breadth and richnees of experience that might have been theirs. From the vieual exploration and manipulation curing infancy, to the varied and varying manifestations of curiosity during the years of chtldhood and throughout the whole IIfe of the aduit, the native interest in new objects and experience persiste.

Hockett and Jacobsen ${ }^{2}$ Indlcate the importance of the echool's role In relation with the environment. Since the school is the institution set up for educative purposes, one would fustifiably expect it to provide for children a richer, more varied and stimulating onvironment than extsto in any other place in the commity. It should be the very place designed to serve every legitimate need of child nature. Here ahould be encouraged all of chlldhood's insatiable demand for activity, for new experience, for investigation and exploration, for all forms of abclal inter-course, and for aesthotic and enotional enjoyment. No matter how Fich the classrocm and sehool wight be, they are but a part of the larger environment in which the child lives. Therefore the walle of the school need to expend to include all that 1o useful and significant in the outside world.

\footnotetext{
Ibld., p. 125.
} 
II Definition of an Excurbion as

Used in This Study

An excursion may be defined as an educational procedure in wich pupils are taken out of the classrook, for educational reasons, to places where the terials of instruction may be observed and studied directly in their functional settings.

Various authors refer to educational visits by other such terrs as the following: field trips, school joumeys, pilgrimages, school tours, and field studies.

Koon refers to the school journey as a long trip lasting several days, an excursion as a visit to some metropolitan area, and an exploration of natural phenomena or simple activities as a field trip. 4

Mckown considers the short journeys to near by commercial plants or public buildings, etc. as trips; and excuraions as longer, less frequent jants to more distant points which consume more than one day's time. 5 otto points out that it is difficult to determine

\section{3}

Cline Koon, School Use of Viruel Aide, Washington: United states Printing office, 1938, p. 23.

4

Harry C. HeKown, Extra-Curcicular Activities, New York: Macialilan Company, 1937, p. 268.

5

Henry J. Otto and Shirley A. Hamrin, Co-Curricular Activitieg in Elementary Schools, New York: D. AppletonCentury Compary, Inc., 1937, p. I2. 
whether a visit by a class is a trip or an excursion. If time and distance are the distinguishing factors then in larger cities an event wich would be a trip would in a smell town turn into an excursion, or vice versa.

The terminology is relatively unimportant, the chief point of interest being the ldea back of the excursion that is to study the objective terial in its natural setting.

This study, using the terms excursions, school journeys, or trips aynonymously, is concerned with those short vislte that involve anywhere from a few minutes time but not more than one school day's duration.

III Kinds or Types of School Excursions Lany classiflcations of excursions are given in literature, but those four divisions as outlined by olsen are presented here because of their inclusiveness.

\& "Curricular area involved" -- Excursions may relate directly to a conventional academic subject such as history, to the study of social processes such as making a living, or to social problems.

B "Primary purpose sought" -- The excursion may be used as an introduction, during the study, or as a culminating activity of a untt or problem studied.

\footnotetext{
Eaward G. Olsen, School and Communtty, New York: Prentice-Hall Inc., 1945, p. 150.
} 
School journeys may be undertaken for many specific reacons, among which might be any or several of the followIng as listed by Hoben:

1. "To aerve as a prevlew of lesson and to gather instructional materials."

2. To create teaching situations for cultivating keenness, observation, discovery, and to encourage pupils to aee and know things about them."

3. mo serve as a means of arousing specific interests....n

4. To oupplement classroom Instruction or to secure definte information for apecific lesson....."

5. mo verify previous information, class aiscussions and conclusions, or Individual experiments."

c "Achdentc level ambraced" -- The purposes, planning arrangements, disciplinary problems, and followup activities of the excursion will differ somewhat accordIng to the grade levelo.

D "Amount of time required" - Bxcureions may occupy these varlous amounts of times

1. Those occupying a class period such as going to the school yard for an arithetie lesson in measurements.

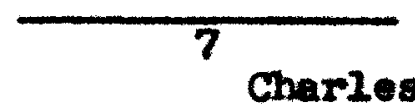

Charles F. Hoban, Charles F. Hoban, Jr., and Samuel B. Ziamen, Vigualizing the Curriculum, Hew York: The Cordon Company, 1937, p. 45 . 
2. Those occupying a morning, afternoon, or a day such as a trip to a court house or a museun.

3. Those that may take a Ionger period than a day. School excursions, as it appears, are of multiple type, depending upon the inter-relationship of these factors. But the important thing is not a meticulous classification, but a clear awareness of the purpose of the trip, and that a varied organization is needed for the different types of excursions.

IV Values or Advantages of Excursions Many and varied are the values or advantages that have been cleimed for excursions by the writers of educational literature. Excursions that are carefully planned and guided result in a variety of outcomes. Some of these are values that are difficulty or impossibie to procure through any other type of activity. An excursion may involve any one or several of the following values:

A Breursions present subjects being studied in their natural settings or as they function. In this way they enrich and supplewent curricular experience. For example, a visit to a paper mill.

B Bxcurbions offer the concrete evidence necessary to clarify instruction for better pupil understanding. For example, after a visit to rallway station, the subject of transportation becowes more real and a vital part of the 
pupils' experiences. They begin to realize the close relationship between what is found in books and Iffe itself. The printed work becowes a living terial, weaningful in its connotations, and a syrubol for wat the pupils have 8 heard or seen.

c School excursions stimulate and exterd children's interesta. Boys and girls like to go places and see things. A trip may arouse students' interest in new areas of thought and activity, oometimes leading to further individuel reading and exploration. Then too chool journeys may stimulate thought by raising new problems. These may be used to introduce a group of pupils to a new field of knowledge, to orient trem, and to help in bullding up background of information and experience for some particular unit of work.

D Trips give education decidedly practical direction as they involve a study of the reallties of life. In this way they eliminate the break between-in-achool and out-of-school life, thus increasing the continuity of the learning processes.

School journeys provide experiences out of which echool activities become more meaningful. School activities of children for too long have been isolated from the outside

\footnotetext{
8

Lester K. Ade, Expanding the Classreom, Harrisburg, Pa.: Department of Public Instruction of Pennaylvania, 1938 , p. 8.
} 
world. Trips help in bringing the outside world into the school and of taking the school into the world.

As a connecting link between the school and community, excureions may arouse public interest in the school. In such manner a community spirit is created as well as a development of training in citizenship.

E Excursions serve as effective means of correlating the aubjects of the school curriculum. A aingle excursion may provide experiences which will be of value in the understanding of number of other subjects besides the one of which the excursion was a part.

As an example safety first functions in a practical way through the observance of safety rules en route and at the place where the investigetion is conducted.

E Excursions offer opportunities for keenness and accuracy of observation. "Observation means more than seeIng; it weans eeeing and interpreting; direct touch wi th the objects of knowledge; the stimulation that comes from the discussion of the group; the challenge to equal and surpass the one who sees, understands, and gives evidence of alertness and matery -- all these are an outcome of school journey procedure, and this procedure offers an effective channel through which these powers may be directed."

\section{9}

Charles Hoben, Charles Hoban, Jr., and Samuel Ziswan, ope cite, p. 42 . 
Q Bxcuralon Involve the consideretion and solution of probloms arising from individuel and group participation in natural social situations. In making trips there is a real opportunity for ohoosing, purposing, planning, exocutIng. and ovaluating on the puplls" part. Planning the trip. oarrying it through, and ovaluating it from many angles are not artiflolel but real experienoes. Here 1s real opportunlty for expreasion of inftlative and the development of leadorahip, oooperation and followerahip wust also be pratioed durlng a voll plamed trip. Thro class trips are notoworthy opportuntties for training in oftizenship.

E Trips stimulate nerration and diousaton. Pupils 21ke to tell or write about things they have heard, eoen, handied, or expertenoed.

I Excuratens orfer opportunities for the profitable ues of lelsure time. Thoy arouse interest in furthor exploration. Cnliaren ofton go on trips with perents, after having diseovered the idea through the school excursion. Erouralons make the ahild wore alert when the farally takes arip.

I Thoy provide actral soureo material for study. They melo possible a widor range of learning from aetuel 11 fo stuations.

I Excursions furntion comon expertences for all children. 
L Tripe provided for the acquisition of accurate definite first-hand information and sensory perceptions which cannot be experienced otherwise. Often trips are essential means of securing first-hend information on topics that teachers cannot treat satisfactorily within the four walls of the bullding. Seeing thing first-hand, hearing the nolse of the wachinery, feeling the heat of the furnace, etc. 18 different than reading about or seeing pictures of thes. By such, eppreciations and attitudes are built up through direct contacts not attainable in any other way. Children can be guided into seeing the value of information obtained directly through first-hand contact. "F1rst-hand knowledge is realistic and dramatic and there-

14 Excursione offer rere opportunities for growth of worthwhile attitudes and better undergtanding between teacher and pupils. While sharing the pleasures and intereste of a trip, the group member are inevitably drawn into more intimate acquaintence. The teecher begins to seen more of a Friend, instead of a taskmiotress. She appears as a muman being enjoying many things students also do. Unexpected interests and poesible talents, in the hitherto afficult troublemaker or the shy student, may be discovered. Shy

\section{0 \\ F. C. Borgeson, "Ixcursions in School Life,"} Mational Fiementaw Principal, 113462, April, 1932. 
people often come out of thelr "shell" during a school journey.

11 Meaches civic, economic, and social inter-dependence and relationships of all people. It helps as much as any ingle factor to eradicate provincial and social prejudices." ${ }^{\mathcal{L}}$

Q School journeys arouse interest in and sympathetic understanding of the problems and social contributions of the varlous vocations. Textbook experience only partially succeds in this, resulting often in an impersonal or detached attitude.

I Excursions provide opportunitiee for bullaing character through the prectical necessity of developing such traits as patience, courtesy, sportsuanship, cooperativeness, and the like.

"The degree to which these and other values result is contingent both upon the soundness of the point of view from which excursions are undertaken and upon the skill with which they are planned, conducted, and utilized."

$\checkmark$ Limitations of the Excursion

Despite Its evident advantages or valued as listed

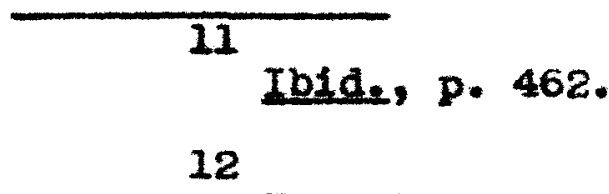

Ermest Horn, Methode of Instruction in the Social Studies, New York: Charles Scribner's Sons, $1937, \mathrm{p} .410$. 
above, the school excursion as a technique of communtty study has several definite limitations. Some of the following merit recognition:

A Excursions may mean a disruption of the school program. In most schools, unless rigld schedules still prevail, excurstons are now deemed of sufficient educational value to permit the use of school time. However, other teachers and classes are often interrupted and burdened with the placement of those chlldren wo for various reasons cannot take the trip wh their awn class group.

B Inclement weather often prevents or postpones a trip just when the interest is at its highest peak.

\& Excursions require great deal of careful organization that may involve too much time on both the teacher and student's part. Then too problems of transportation and weather conditions my defeat the purpose and planning for the trip.

D Puch time may be wasted in going to and from the objective.

E There mast be a restriction or Iimitation to occasional trips. Despite the many pupils' interests, the class can be allowed to pureue only a few of these through excursions.

E There my be lack of cooperation on the part of the personnel at the places to visit. The danger of exhausting the patience of the people in charge of places 
visited may become a problem. With some sources this would bo no problem, while in others it bay boome one rapldiy. There noeds to be at the educational hoadquarters a department through which excursions can be oleared.

a Transportation for a class excursion presents a problem. Three phases of the problen are presented here: 1. Lack of tranuportation facllities is one of the greatest obstades to the use or excurrions when objectives carnot be reached by foot.

2. If buses or atreet care are acossibie the element of expense is inevitable. Host sehool budgets do not provide for class excuratons as they do for othor learning atds woh as books and axdio-visual equipment. If pupils mat pay thelr own exponse, then the exeursion cannot be a required activity.

The ldeal way to meet the expense incldent to the trip and the problom of transportation difficulties would be to have sohool buses. Money in the sohool budget for elass trips may be another alternative. The Parent-Feacher Assoclation could have spocial funds trow which car or bus faro might bo obtained for those children tho are umable to pay their om tranoportation. With voluntery permanent motor comeftter from the Paront-Feacher Assoolation, trips might be made at no coat to the ohildren, also with a minimum of 
13

time and phyaical effort. As olsen points out, private automobiles posess the further advantege that they do not make the group as conspleuous to the general public as does the use of bue transportation.

3. The use of transportation facilities involves dengers. Legal aspects in regard to liability have preeented obstacles.

Sometimes these transportation problems are 80 inaurmountable that the teacher ts compelled to abendon any plans for trips.

I Too much reaponstbility is involved in taking excursions. Class tripe have more inherent possiblilites of danger than does the average clussrocm. The teacher must be constantly alert to avold any injury. Definite instruction about the trip wust be given to the children. Hodgdon recommende that a printed mimeographed copy of the regulatlons be given to the chlldren and that parents should recelve a copy as an Indication that everything possible is being done for the benefit of the chlld during the trip. Required notes of permission from parente should be obtained. See the sample in the Appendix.

\footnotetext{
13

01sen, ope citte, p. 308.

14

Deniel Hodgdon, "Llability and the School $\mathrm{Tr}$ p" Clearing House, 17:434, Mareh-Apri1, 1943.
} 
If private automobiles are used adequate liability insurance should be carried. Otherwise the legal riak for both driver and teacher is too great.

I Children are not always able to see specific items because of too large number on the trip.

I Sometimes there is so much noise frow the machinary at the plant that the guide cannot be heard by the group. 5 Guides often are not trained to talk to children In terns that they are able to understand.

Some of these difficulties are not ent1rely incurmountable. Others may be overcome by the cooperation of the school and the communtty source.

\section{vI Recent Studies and Investigations}

The concluations as to the values of excurstions such at those liated above, are besed chiefly upon the eritical judgment of persons who have had experfence in their use rather than upon statistical advantages.

In searching the ifterature very few studies were found that have experimented scientifically of th the excurclon. A few of these surveys and experiments will be briefiy deecribed here.

A The R. H. Price Study

R. H. Price conducted a study to determine the extent to which excuralons were being made by the public elementary schoola, the type of place chosen for those, the time of day 
or week devoted to them, and the principals' judgments of their value.

From his otudy ${ }^{15}$ visits to libraries $(86.9 \%)$ and museums (84.3\%) ranked the highest of places chosen to visit. $53.1 \%$ reported trips during school hours, $4.8 \%$ reported trips after school hours, and $42.1 \%$ reported trips both during and after school hours. As to the values most of the schools in which trip were taken considered excursions a a regular part of the school progran and not an extracurricular activity.

B The F. C. Borgeson Study

In 1930 a aurvey of extra-curricular activities in five hundred twenty-four elementary schools wes taken by F. C. Borgeson of the Department of Education in New York Univeraity. He classifled the excursion under this category and devoted one section of his questionnaire to it. In the survey it was noted that tripe to the various places were taken in the following order, according to greategt frequency; muscum, fleld trips, parks, fire departments, historic landmarke, factorles, zoologlcal gardens, post offices, banks, and greenhouses.

Two experimental etudies, one by R. W. Grinstead and

\section{6}

R. H. Price, "A Study of the Values of Field Trips," Hational Elementary Principal, 13:302-303, June, 1934. 
the other by Henry Atyeo, attempted to measure the contribution of the excursion when used to supplement elass room instmotion in the acquiring of information.

c Reaults of R. W. Grinstead's Experimental Study Results of Grinstead's experimental study were obtalned from Atyoo's ${ }^{16}$ alssertation and not from the original thosis.

The search for means to gauge the value of the excursion technique other than opinion, led to Grinstead's attack upon the experimental evaluation of the prooedure. Grinstead carried out, under carerully controlled conditions, four experiments with clasaes in comerctal geography in a Pasadena, Callfornie juntor high school. This was in order to compare the relative increase in information produeed by the excurstion and by elassroon diseussion of the same tople supplemented by class demonstration, motion pletures, and other means of vitalising the study.

Grinstead found an average of sixty-five per cont more gain in knowledge to have resulted from the excursion, also the use of the exoursion as introduction to topio seemed to produce greater gain than when used a a anmary or a review the close of the study of the topic.

\section{6}

Henry Atyoo, ope c1t., p. 172, oiting $R_{*}$ W. Grinstoad, Bxperimental Braluetion of the School Sxcursion. [Los Angeíe], 1920. 


\section{Henry Atyeo's Experimental Study}

Henry Atyeo's study was made in White Plains, New York. This tudy consisted of two experiments undertaken to determine the increase in factual knowlodge, the speciflc type of knowledge acquired, and the increase in interest resulting from the ure of the cless alscussion method supplemented by the excursion technigue in teaching unite of ancient history as compared with corresponding reeults of the class discussion method wen used alone.

From the six excursions used messurement of the differences in information acquired under the two methods of instruction showed the euperlority of the gain wade by the excurstion group in both experiments. There was ilttle difference in the perticular kind of information acquired by -1ther group. Membere of both groups showed Interest in doing the things which they had boen learning to do.

Atyeo points out that the reaults of the experiment proved that the excursion used elther alone or as a part of the class discussion method poseesses value which is in many ways auperior to thet of the method with which it was compared, but that further experiment is needed to study the other values comonly attributed to excuratons.

E James Fraser's Study

James Fraser's study wes to measure certain possible outcomes, and to examine the relationships among those out- 
comes, In testing the thesis that the study excursion is a valuable technique for Implementation of the phllosophy of general edueation.

For the study Fraser used the 1938 Lincoln Sohool Senfor class of twenty boys and twenty-six girls divided Into three groups in the American eulture course.

Outcomes were measured as growths, losses, or changes by series of "before" and "after" tests. Measurement was made not only of growth in information but also of change In attitude toward important public issues and growth in ablilty to 1dentify, to apply prinelples, and to generalize.

The results of the study justifled the conclusion that the study excursion, as an educational enterprise. is capablo of producing outcomes other than gain in factual knowledge. However, the resultg did indicate that gain in information is probably the best single measure of all the outcomes ovaluatod.

These provious seientifle studies hed been designed to evaluate the excursion in the secondary school, none in the elementary.

\section{E Blia Clark's Experiment}

BIIa Clark's experiment was made to determine what contribution the excursion might yleld in four sixth grade units, Egypt, Printing, Pransportation, and Commanication. Throe hundred thinty-five sixth grede ohlldren took 
part in the experiment in Minneapolis. Control and experimental groups were given the same material content, and the same amount of time on each unit. Sehools were rotated being one time the control group and next the experimental group.

The experimental data eame from regular classroom situations that were closely planned, but in which a deIiberate attempt was made to create no abnormal situations. The purpose of the study was to eveluate as well as possible the excursion when used in a natural school onviroment. This study ras planned, not only as a dovice for securing rellable date through collective research, but also as a toacher training tochnique.

The evidence presented through this study pointed to the definite need of careful preparation in the use of an excursion, also that teaehers must constantly evaluate the excurs fons they use.

Q Dwight Curtis' Study

The purpose of the Dwight Curtis study was to measure the contribution of the excursion procedure when used as a sumary device to the understanding of content material taught in the classroom by a highly illustrative method.

Thlety-two fifth grade children of the University of Iowa Elementary Sohool divided into two groups took part in 
the atudy * Four experiments were condueted during the study of the unit on erosion and conservation of so11. The problem approech was used in teaching the material in oach experiment. The excuraion followed a planned three step procedure: proparation, trlp, and follow-up. The purpose of the tests arter the trips were nade was to test the ability to seo relationships, to organize in sequonce essential relationahips in the problem, and to recogalze and apply prineiples in new altuations.

Curtia ${ }^{17}$ recourendi that exeursions not be given just an alloted time in the soclal studies or other subject periods, but be used as a mejor instrunt of instruction In cases where 11 lustration of subject metter is readily sceossible in the commity and especlally in cases wore the concrete experiences of the pupils have been $11 m i t e d$. Swmary - In all the atudies the excursion has been found to be valuable teohnique, especlally in the gain in factual knowledge. They also indieated the need of careful pleaning and evaluation for successful excursions.

\section{The School and the Commanity}

The school te not a minleture soolety, as it does not mirror any elty, state, or distriet even in tho erudest out-

\section{7}

Delght Curtis, "Contribution of the Excuraion to Understanding, Joumal of Edueat lonal Researeh, 38:210, November. 1944. 
11ne. The school is but one part of the local and larger community oith the function of preparing children to live in that comonity.

The elementary school has for the most part been the sohool of the people. Yet, too often 1ts activities have frequently been remote from the day-by-day coneerns of the comemunity, and often the comunity's resources have been 11ttle used by the school in the equeation of anlldren.

Iocal enviroment and events offer a vesith of instruetional material much of which oamnot be unfolded to children except through direct means. The activities of men, in his multifartous ways he uses for earning a living and living iffe, can be best presented to ohlld through alrect observation. This is the function of the excursion. Boys end girls actually are interested in the activitles of the commity. The school which follows up these interests provides a rich and varied curriculum. From such community study chlldren grow in the habits, attitudes, and knowledge which they nood in order to be good citizens, today as boys and girls and tomorrow as men and women. Within overy comminity, large or ame11, I1e untapped opportunitles for valuable oducational growth. The school an rlahly extend 1ts curriculum by utllialng local re-

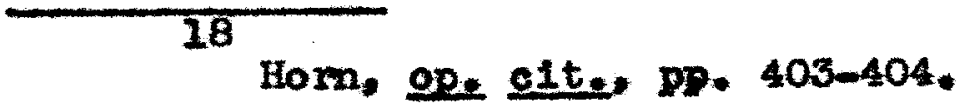


sources through commity experience.

The community is always at hand as source of information. No matter what sort of problem is being studied, there sourees of information within the comenulty bear Ine upon some phase of that problem. Sintlarly there are representative examplas of the entire scope of living withIn the community.

"As opposed to making a deliberate study of what is In the commity. It often is more valuable to call upon the resources of the commity to help solve problems ariaing in the schoolwork." 19

Frequent and continued use of the communty for observation and participation in various social processes can glve children an enriching educational experience. This depends upon the akill in which the school uses the commanty a a laboratory for developing social understandings.

To withhold the rlehes of understanding and experience from the ohlld by keeping him in the elass ontirelg is no longer tenable. Too great an emphasis has been placed upon book facts with fallure to provide valld impresalons, appreclations, and attltudes needed. Children often leave sehools really uneducated in spite of ractual learnings.

\footnotetext{
18

Clarence Humnioutt, and George Omeby, "Vt1112ing Commity Resources, "The Instructor, 46:10, Janusry. 1940.
} 
Too many trips may be possible. Enthusiasm over buccessful trips may be so great that the olass wants to solve every problem by "going to see." Too many trips reault in disipation of the pupila' energy, Juat as too many class activities attempted at once bring about confusion and a vaste of valuable opportunities and time. Here a diserinInatling judgment 1. needed. A fow carefully plannod trips is better than many that do not make the nost of the1r possiblitios.

Often there are problems to be feeed in undertaking an exeurgion program in the communty. Thexe must be developed a falr polnt of view toward woh a prograw in the community, because a trip conoems its chilaren, its settings, Its amployees, and 1ts educational expenditures. There may need to be broken down the traditional belief thet any educetion obtalned outslide of the sohool bullding 1 chop. There are two possibilities in this connection. One, to plan and conduct a fer trips to prove the value of the activity. Another plan is to oducate the community. In 1ts support, and then promote the trips. The last seens to be the more desirable. The demand for suceesaful trips will bo greater and thas stimulating in teaching. Certalnly any procedure to begin a now progran Fequires tect, knowledge, and wholehearted bellef in the soundness 
of the enterprise.

Sohools or teachers, in plenning a program in which excursions are used as a learning activity. will find it valuable to make a complete prellminary survey of the opportunities for them in their community. These may include places, situations, points of interest, or people that w11l give meaningful content to the eurriculuan and school activities. If the tercher does not real1ze the potentialities of the comrunity she cannot succeed in guldIng children to take advantage of the resources. Every comonity has some possiblittles in this regard, as has been pointed out.

This inventory will require several exploratory expeditions that would be worthwile. This survey could be an entire sohool system project in which principals, teachors, and children covid all hove a part or this could be a profeasional study project for all the teachers of the entire system with representative coumlttees of teachers to complle the inventory Inforwation. This might ereate an "excursion conselousness" throughout the system.

"A combitteo of teachers in Oakland, for instance, hes printed in bulletin form such an inventory of usefwl

\footnotetext{
20

Harry HoKown and Alvin B. Roberts, Andio-V1sual Alds to Instruction. How York: MoOraw-H111 Book Company, 1940, pp. 195-196.
} 
trips made by group of teachers. This is avaliable to all the c1ty teachers and includes helpful description of actual excursions." 21

Tho San Jose wohool system issued a leaflet entitled "Interesting Places to V1sit," which ineluded sugsestions on proparing for trips and list of possible fourneys organized around mejor community activities.

Prom the survey's assembled list a teacher might choose the perticular exoursion which meets her purpose in bringing the rlchest experience to the children. 23

What places might be Included in the survey? Weaver has prepared an outIIne for making a survey of the commulty which could be very helpful. Although prepared for metropolitan centers it can give suggestions for other comnunities. His outline which follows, suggests excuralons to be taken as anawers to vital questions: 10vels Iiver

1. How do poople on vartous goetal and economie

2. How can housing for the poor be improved?

3. What are the raciel and religlous groupings of the comanity?

21

John Hockett and $E_{*} W_{*}$ Jacobsen, ope cit., p.138. 22

Henry Harap. "Scope of An Effective School Program For Ut1lizing Camunity Resources," Hational Blementary Princlpel, 18:455, July, 1939.

23

David A. Seaver, "Excursions in a Petropolitan Center." Thirteenth Yoerbook of Department of Elementary Sohool PrInc1pels, Washington, D. C., 1934, pp. 292-293. 
4. How does the city get its power?

5. How do people make a living?

necesaltien?

6. How and where do people get their life

7. How do people travel to places?

8. How do people ecmminicate?

9. How are people Informed about eventa?

10. How do people govern themselves?

11. How are people protected?

12. How do people enmich their livee?

13. How does a particular community exchange producte with the outside world?

14. How do people work towards enother social order? Mecallum glves the following list of places for visitation that might be found In every locality:

1. Government bullaings

2. Public utility builaings

3. Industrial plente

4. Librames

5. Museume

6. Transportation facilities

7. Public protective agencles

8. Community centere

9. Cardens

10. Publie service agencies

11. Stores

12. Publiahing houses

13. Farmo

14. Public bullaings

15. Construction work

16. 2008

17. Airporte

18. Radio stations

19. Bxpositions and exhibits

20. Historical monuments, teblets, and statues

Juet knowing what places to viait is not enough, but

It is necessary to evaluate their ouftability and value for

24

Jessie Hecallum, "All Aboard for Exoursions," Department of Blementary School Principale, 11:456-456, Apri1, 1932. 
visitation.

"Bvery discovered resource center should be approsohod, through a personal intervisw if possible, in order to discover whether it is willine to cooperate with a program of sohool visits, what facilltios it has and what provisions may bo made for such excursions, and the extent to which student'a observations the would probably correlate with their sehool program." 25

It would be a good plan to comp110 cortain facts or pertinent data regarding each one of the places to be visitod. This information might be tabulated in some form which would be conventent for reference when arrangenents were bolng made for a visit to particular place.

Such information as the following should be included:

1. Name of place, person, or thing to be visited

2. Location

3. Reason or purpose for selection

4. Educational values to be sought or stressed

5. Age groups or grade levels which might profit from the visit

6. Subjects to which it is best suited

7. Transportation needs

8. Time appropriate for visitation

25 01sen, oge c1t., p. 151 . 
9. Nane of person to contact

10. Preliminary notification

(a) Time nocessary

(b) Form

11. Generel attitude of the offielals concerned

12. Number of visitors allowed at one tive

13. Guide, exhiblts, V1sual alds, etc. avallable

14. Possiblo safety hazards

(a) Praffic erossings

(b) Unguarded maohines

(c) Dangerous streans, etc.

15. Time necessary for making the trip

26. Sugfestions of materials and methods to be used in proparation for the visit

17. Roma rka

Hecallum suggested that in this space for remarks such accumulated comments such as, "Don't wear your good shoes when you go to zoo," to be added after trips have beon made. These would prove unusually valuable for subsequent trips to the same place.

AII of this information could be fliod, Indexed, and accessible to all teachers at the Library or in the Audiovieual Education Department at the Board of Edueation. Per-

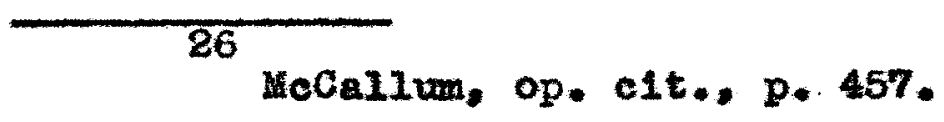


haps, It woulo be better st1li for mineographed coples also to be sent to each school. Then the Indiviaual schools might add any inforition to the survey data pertaining to the relationship of their school and the sources avallable. Ang list of exoursions should be subjected to continual revision as new objectives would be added from time to time, end some may be diropped. Bach school might neke a large map and plot various places avallable for visitation and indicate the best routes and means of transportation for reaching the points of interest.

After obtaining this valuable and pertinent Informtion, tho next and obvious step is using these resources by such neans as excurstons. The administration of an excursion will be discussed later in Chapter V. 
CHAPTER IV

SOURCES IN LOUISVILLE FOR EXCURSIONS

IN RELATION TO THE UNIT, "THE OHIO VALCEY" 


\section{SOURCES IN LOUISVILIE FOR EXCURSIONS \\ IN REIATION TO THE UNIT, "ThE OHIO VALLEY"}

I Brief Description of the Ohio Valley Unit

The social studies unit, "The Ohio Valley (Middle

States)," was produced by a combittee of the Louisville

Board of Education Division of Curriculum and Research under Dr. John Dotson. This unit was distributed in January, 1947, to overy elementary school to be accessible to all fifth srade toachere. It was considered a sample unit to be ueed by any fifth grade teacher so desiring.

The unit is both a historical and geographical one. Why the two are inter-dependent in teaching this unit is well explained in the introduction.

"The otory of how these ploneere found their way through Cumberland Gap and explored, occupied, and gettled the vast fertile land of the ohio valiey is a faceinating one. A knowledge of this historlcal background is an aid in understanding the development and present status of the Ohio Valley."I

"To understand and appreciate the contribution of the Ohio Valley to the nation today and in times past, pup11s must know the story of the historical background and the Influences of ellmate and natural resources upon the industries and lives of the people."2

\footnotetext{
1 "The Onlo Valley (uidale States)" p. 1.

2 "The Ohio Valley," clting The Intermediete Henual [Cinetmati], 1945.
} 
It was suggested that because of the historical connectlons, the unit would inelude not only a study of West Virginta, Ohto, Kentucky, IIlinols and Indiana, but also a study of MLohigan and Wisconsin whioh are often referred to es the Mldale Stetes.

Besides the suggestive blbllography of books for both teacher and pup1ls, audiowisuel alds such as the following were auggested to be used in enriching the unit: motion plctures, film strips, globes, maps, recordings, and trips to suggestive historic spots in the region and to histioric spots in Loulsville pertaining to this unit.

As previousiy Indicated, this study is ooncexned wth the latter, visits to spots in Loulsvilie pertaining to the unit. "The onlo Valley."

II Information for Vialting Avallable Sourees When teaching the soelal atudies untt, The Oh10 Valloy, the class group consisted of forty-eight children twenty-eight boys and twenty girls -- for the sooila atudies period only. As the group was large, the writer folt a decided need for many and varlous activitios to maintain an interest in the unit. In the group's planning for the study of the untt several auggestions and eativit1es were 11sted. One of which was the suggestion to make class visits to places in their own elty as Loulsvillo wes a part of the Onio Valley. 
What were the best places to visit, as tine would not permit many excursions? which places wero avallable now as during the war emergency many sources had been closed to the public? These were the basis. for the undertaking of this study.

In the unit the curriculum connlttee had suggested. only historic spots for visiting. See the list in the Appendix. Other places that night be added to the list not only of historic but of goographic interest were sought. AII the names of the sources that could bo found by the witer, suggested places from discussion with several teachers, and others mentioned in the third grade unit, "Loulsville Todey," wero complled and classifled. These were included in a questionnalre sent to fifth grade teachers to be rated, required or optional for a better understanding of the unit, "The ohlo valley." The questionnalre was also deslgned to diocover what teachers had taken trips in connection with the study of the untt in order that they might be Interviewed later. A copy of the questlonraire and the questions used in the interviews will be found in the Appendix.

This questionnalre was sent to fifth grede teachers who had taught the unit and to those who were familiar with the content and make-up of the unit, but who for various reasons had not taught the unit. 
The names of the fifth grade teachers were obtatned from the Loulsville School Directory for 1946-1947. These teachers included not only those who were taaching a stralght fifth grade, but also others who had conbined grades as $5 A-6 B$.

Before a questionnaire was sent, each of these teschers was directly contacted to see if she were one of the two types mentioned above. All total fortj-five quostionnalres wore sent and returned. The tabulation of these way be found in the Appendix.

The results of the questionnaires will be briofly sumartzed here.

The Objections to Class lexcursions as a Result of the duestionnalres to Fortj-five leachers Actual No. Fercent

1. Too great a respons1bil1ty 10 22.2

2. Too much time involved in gettine to and from the objective 18.8

3. Difficulty of handing large groups 3 6.6

4. Children do not get onough benefit to justify tine and effort involved $0 \quad 0$ Other Objections Added by the Fifth Grade Teacherg 1. Excursions dismupt school program 2. Curriculum too crowded 3. Other afterwohool activities for ohildren interfore 
4. Lack of transportation

5. Transportation 18 inadequate or inconvenient

6. Excurgions require too mich organization

7. Children are unable to pay for transportation

8. Difficult to get children to bring consent notes from parente

9. Many places won't permit vialtors especially chllaren

10. Safety hazards in visiting some sources

21. Too diffieult to concluet the ontire claes on a trip. If a comittee is taken, this meane after school hours. The school day is too stremuous for added trips after ochool hours. Faculty and supervisor meetings often interfere with planned trips after school.

Some of the teachere did not object to trips, but gave the following reasens on the questionnaire for not making class excurations:

Actual No. Percent

1. Schedule too heavy $6 \quad 13.3$

2. Problem children in the classroon 920.0

3. Too mach work involved 1 2.2

4. Lack of conventent trangportation $25 \quad 33.3$ Other reasons addeds

1. Three divisions (as $6 \mathrm{~B}-5 \mathrm{~A}-5 \mathrm{~B}$ ) and not enough children were dolng the same thing that a trip could be taken to be beneftclal to all. 
2. Time could not be arranged to advantage

3. Would have to dismupt another teacher and classroom to leave behlnd those chlldren who covidn't $g 0$

4. Too fow chilaren who could make trip (transportation cost or paronts unw1111ng)

5. Dian't know what plaoes would be nost bonerlolal to 1a1t

As a result of the questionnaires five of the nost popular sources as reted by the fifth grade teachers are the following:

1. Bowman Fleld

2. Loulsv1110 Fortland Canal

3. Speed Huseum

4. Courier-Joumal

5. Bairery

For the results of the other sources see the tabulation of the questionnalre in the Appendix.

These five sources cannot be consldered "the best" places for visiting because other places not included, due to overgight of lack of knowledge of their existence, on the questlonnalre were added by the teachers. These include the following:

1. American Radiator and Standard Sanitary Corporation

2. Armour Creamertes 
3. General Plywood Corporation

4. Padiey Pottery

5. International Harvester

6. Loulsvill Soybean Products Corporation

7. Fuper Companies

8. Iuritan Cordage milis

9. "The OId Kentucky Home"

10. Tobacco nanufactures

11. Tobacco warehouses

Information, ar to wat way this study might be beneflctal to fifth grade teachers, was obtained from the questIonnalres, from interviews with ten teachers and with the curricultu compttee authors of the unit. One sact that stood out as generally acreed upon was the destre for the following information:

1. What places are avallable for visiting and their 1ocation:

2. How and whom to contact in making arrengenents for a visit?

3. What days and hours may the sources be visited?

4. How many children may visit at ono time?

5. Is a gufde provided?

6. Are there any hazards or dangers involved?

Because of this desired and requested information all the sources, referred to sbove, will be described briefly 
along with the required infomation for visitation.

I Business District

4 Hain Stroet

Hain Street is a long old street near the river which mus aoross tom. Blocks of 1 t are made up of holeane bouses.

\section{B Tho Naymarket}

The Haymarket for poutry and produce, between Brook and Floyd and ILberty and Jerferson, prosents meh activity durting the dey.

Here is stall after stall of almost every kind of food one would want. The maxket has been deseribed as a falr whero everyone 18 on the midray. Bverywhere poople are oulling thelr wares for sale whether it is from the flower stands, vegetable booths, or frult stancis.

The llaymaricet orfinated in the 80 'a when farmers gethered in an abandoned rallroad yard to sell their produce, Ineluding bay. Then bulldinge began to crowd the area. the farmers fermed a stock company wish oms the property todey. Theve one hundred fifty growers tho wake up the oorporation are ealled The Gardeners and Farwers Maxket Company. The ownors charge only fifty conts a day for a stal1, but a dollar on Seturday. Tho market furnishes olectric 1ights, garbage oollection, and provision for changling money. 
Th1s was at pirat a wholesale market only as the reta11 stalls were not begun unt11 1931. Now the retallers have about fifty stalls. Throe hundred stalls are providod for the growers who sell to the retallers, hotels, restaurents, grocerles, truekers, or anyone wanting large quant1ties.

The truckers, remining on the south side of liberty across the market plaza, come from many states such as Mlchigan, Illinola, Ohio, Florida, Texas, and others. These truckers do not produce anything, but they just buy where products are cheap and plentiful and take to another maricet mere the producte are scaree to sell at a profit. The manager for the Famers Market, Mr. Grover Howe, sees that the truckers sell only products that home growere do not heve so as not to be competing.

Disobeying any of the rules means no more trading at the Haymarket.

Children may come here without permission.

For any Information contact Mr. Grover Howe or thr. Kahlert at the office in the contral part of the market. Other Interesting places may be seen on trip to the Haymarket. At 114 Fast Jaffermon 18 one of the oldest houses in Loulsville. It was built in 1827 for Benjamin Smith, a southerm planter, who retired from his plantation and moved to Loulavilie. The building is of Greek arch1- 
tecture. The four 11mestone columa at the front were carved by hand and the original handwrought Ironwork and 11ght standards are still in use. Insfde there is a spiral stalrway extending from the first to the third floor, Itallan marble mantel plece, mahogany woodwork, and finely etched glas decorations. This wes one the Unton Gospel Hasion, but now is knom as the "Central Baptist Mission." For visiting with a elass make arrangerents with Mr. Sherman Towell, the superintendent. Another house that might be seen on this trip is the Grayson House at 432 South Sixth. As it is privato home it can be seen only from the outslde.

This house was bullt in 1810 on an Indian mound by Mr. Gwathey of Virginla. The walls are seventeon inchos thick and are made of brick that was brought on keelboats down the river. This house stood through many windstorms and two earthquakes. The seventeen roons and the large hall of the house have been seenes of many elaborate parties.

The house was later sold to Hr. Dav1d Ward who gave It as wedding gift to his daughter, wrs. Froderick Grayson, for whom the house had been named.

\section{Civie Bulldings}

$$
\text { A The C1ty Hall }
$$

Location - 601 Hest Jefferson Deseription - A trip to the City Hall is both in- 
teresting and educational. The personnel is very kind and helpful in explaining the various departments of the city government.

By visiting the entire bullding. Including the Annex, the children will recelve some ldea of the importunce and complexity of our city goverment. It is not expected that oach department can be studied in great dotall because that Involves time and too much for the children to remember. However, something of the value of each depertment might be loamed.

On the main floor are found the offlces of the sayor and Chlef of Pollce. Other offlces on the floor include the Detective Division, Law Librery, Public Ut111tles, Patrol Captain, Auto Theft, Crime Prevention Bureau, Reporters Room, and the Burenu of Reoords.

On the second floor is located the offlees of the Director of Public Works, the City Englneer, the Clerk of Aldermen, and the Welfare Department. The Board of Aldermon's meoting room is also looated on this floor. It is equippod with some very interesting old fumiture uaed for years and years. Behind a ralling there are some chalrs. On one side of this room seats are reserved for oltisens who wish to come to the meetings. In the front of the room there is a table and chalrs for the chaimen of the neeting and his offleers to sit. 
On the third floor are found offices of the folowIng: Building Inspector, Civil Service Board, Smoke Commission, Cemeterios and Fublic Baths, Division of Parks, Division of Safety. and Police Educational Bureau.

The Fire Alarm Tower on the third ploor of tho Annex is interesting and appealing to children. Visitors are Eladly welcomed there because the members of the department foel that too few pooplo know that it is there. Is is very necessary to the FIre Depertment. On one side of the large roon is a huge instrument board that is connected with every f1re alarm box in the clty. There are three ways in which this board records overy alarm that comes in - a 11ght flashes, loud nolse is heard, and a tloker punches the box number severel times on a strip of paper. In the center of the roon, there is a small telephone switohboard through whloh other alarms are recolved. Above this, there is a recording apporatus that shows just whlch flre ongines, trucks, and hooks and ladders are in and whlch ones are out. In the conter of the room there is a transmitter whict is used to sond the alarm to all of the ongine houses. Brery minute of the day and night, men are on duty to receive and send the alams. Bvery fro alarm, whether false or real, is recorded. The record shows the number of the engine answertng the call, the cause of the ftre, the length of time taken to put it out, the method used, the 
damage dono, and the name of the property omer.

The man in charge lo very cooperative. He w11 send in an alarm so that the children mey seo hor it is reoorded al so ho w111 show them a map marking the places where alarm boxes are located.

In a room adjoining this one may be seen the batterycharging room. This is man by means of 1660 batterles. Every day a complete set must be recharged wile e:sother set 18 being used.

Visiting Arrangements - Fith an appointment at the Mayor's offlce stating the time and the date, a roasonable number of chlldren - average class of thirty-f1ve - may visit the City Fall and be provided wth a gulde.

B The United States Post Offles and Gustoms Bullalng Loeation - On Broadmay between SIxth and Seventh State.

Description - Mis beatiful bullding. near the heart of Joulsville's businoss district, is a dignifled example of Corinthian arehitecture and is a decided addition to the beauty of the city.

Here the boys and girls may see not only whero the stampa are bought but also were packages and letters are ma1led. At the oanceling mechine the children may see the outgoing ma11 boing prepared for 1 ts joumey. The letters are sorted into two plies according to the size of the en- 
velopes. As the letters pass through the machine the atamps are cencelled. Then the letters are taken to a depertment were they are quidkIy soxted and placed in Iarge canva bags, which are locked securely before being sent to the rallroad station or alrport.

The inooming mall is also sorted according to the zones or sections of the clty where the branch post-offlees are located. Mere are ter delivery stations and a truak Is used to taire the mail to these stations. Here the postman pleks up tho mall to deliver.

Another interesting depertment is wore the boxes and bungies ere sorted. Fech peakage is examined to be sure it 1 properiy tied and addressed wen accepted at the rindow by the clexic. The baggage is sent on a wide belt rm by olectrioity to tho department mere it is sorted and made ready for its journey.

Some letters that cannot be delivered, nor retumed to the writer bacause of no retum address, co to a Dead Letter Department.

The upper floors of the bullding house many offlces of the Inited States Goverment.

V1siting Arransenents - The entire class may visit If an appolntment ta made wth Mr. H. M. Jossel, Assiatant Superintendent of MaL1s. 
c General Fospital

The Generel Hoepitel may not be visited by any chilaren under sixteen years of age.

$$
\text { D Jefferson County Amory }
$$

Location -- Fifth and Amory Place

Description -- The Armory is of gray stone with five colurns across the front of the second and thind stories. The tower gives it a picturesque beckground. The two eagles on the front give 1t a military atmiosphere.

The Amory wes built as convention headquarters In Loulsvilie. Today many of the big events are still held here because it offers ldeal acconodations with its ample floor space surrounded by a comtodious balcony. Thore are no plllars to get in the way. You can sit a.most anywhere in the bulleing and soe what is golng on.

Visiting Axrangementa - By making an appointwent vith ur. Irvin wayne en entire class may visit and be provided with a guide.

E Jefferson County Court House

Location - On Jerferson Street between Fifth and

Sixth Streets

Desoription - The Jefrorson County Court House with 1ts wide steps and white colums is of Greak architecture. It was completed in 1859 and considered to be one of the best examples of American architecture. Hero the affalrs 
of both the county and the city of Louisville are taken care of.

In front of the Court House is tho Jefferson Momment glven to the clty by I. F, and Bernard Bemheim. Mhls monument, one of the costliest over erected to Jefferson's memory, was mado in Rome, Italy by S1r hoses Ezieklel and was cast in bronzo in Beriln.

On the outgide of the Court House, near the front door, a marixor has been placed honoring George fiogers Clark. The marken is inseribed thus:

George Rogers Clark 1752-1818

Soldier. Patriot

Founder of Ioulsvilio

Conqueror of Oar First Great

viest from the Allegheny hountalns

To the Halasippl RIvor

A Son of Vireinia

A Gallant Gentieman and

A Great American

A Tribute from the

National Society of Colonial Dames of

Anemea in the Comonwealth of Kentucky. 1939.

On the Eround floor is located the Pollee Department and Maglstrate courts.

In the rotunda of the Court House is a statue of Henry clay. This wite merble atatue was soulptured by Joel $T$. Hart. The people of Loulsvilie by nears of public subscriptions gave 15,000 for the atatue. At the ceromony of unvelilng the statue in 1811. Hr. Hart cane from Foronce. Italy to be prebent. 
In the room on the left of the rotunda is the County Clerk's Offioe where records of property and deedo are kept. This is a large room with many tables, shelves of books along the wells, and in the balcony on the slde books are also kept. On this sarse floor is found the County Judge's Off10e, and courtroons.

On the top floor (balcony) is the circult court and where drivers lleonses are obtalned.

Visiting Arrangerents - A class of around thirtyfive can be accomodated if an appointment is made at the County Judge's Office. A gulde may be provided if someone Is avallable at the time.

\section{F Loulavilie Publie Library}

Location - At Fourth and York

Desaription - On entering the 1ibrary. whioh 2 of

French arehitecture, one sees the beautiful elreulation room. Behind the card catelog are the atack which mey be ontered only with spectal permisalon. On each side of this room are pretty marble steirways. To the right of this room is the reference room where books are kept to be used only in the 21brary. To the left of the elroulation room is located the open shelr room.

In the elreulation room be seen a copy of the Doclaration of Independence in escs like the original one in the Library of Congress in Washington. 
Golng upstalrs one can see plotures or marals in the main room downstalrs. These murals represent comnerce, industry, education, sclence, art, 11terature, and history.

On the second floor are the orlginel paintings of "Hebe" by Canove and "Morming Glory" and "Venus do Wediso" by Joel T. Flart. There are also busts of Abraham Lincoln and Madison Cavein in the corridor.

To the left of the stalway is the library collection of Honry Watterson that he willed to the clty. Adjolning this can be found the Kentucky Roon with its collection of historical material.

On the opposite end of the corridor is the children's room with its low shelves that chlldren may easily reach.

In the basenent there is a museum containing collection of rocks, birds, butterfiles, shells and fossils. Here also is found a mumy, one of the two in the olty. Outside the library on one side of the building is a bronze statue of Abraham Lincoln. It is the work of Mr. George G. Barnard, a soulptor of Pennsyivanta. Mr. Charles Edward thomas of Hardin County, who IIved noar Iincoln's birth place, was the model for the statue. The statue wes given to the city on Ootober 26, 1922, by Mr. and Mrs. Issae $W$. Berraheim.

At the front of the bullaing there is a statute of George D. Prentice. This is the work of Mr. Alex Bouly, a 
Belgian soulpter. Ths flgure was comenced in 1874 and completed in 1876. The white marble, out of which the momument was made, was imported from ItaIy and welghed seventeen thousand pounds. For years the statue stood at the entrence of the Courler-Joumal office Bullding * In 1914, when Goorge Settlo, I1brarlan, loarnod that it was to be given to one of the parks, he consulted members of the comnltteo and succeeded in having it placed in front of the main 11brary.

Mr. Prentice was a journalist, poet, and edueator of Loulavilie.

Visiting Arrengements - For the library to fumish a guide, an appointment may be mado wth of the Ch1ldren's Departurent.

The Husem - Hours for Monday, Tuesday, Wednesday, Thuraday, Friday and Sunday aro 2:00 F.M. to 5:00 F.M. For Saturday they are 10:00 A.M. to 12:00 P.M. and 1:00 P.M. to 5:00 P.M. Gulde - Colonel Beckner. The ent1re class may vialt the masum at these hours.

a Memorlal Aual torlum

Loeation - The Memorial Auditorium oocupies the 1933, p. 22.

"Ioulsv1110 Todng," Loular1110, Public Schools,

4 Iold, pp. 11-12. 
81

northwest corner of Pourth and Ientucky Streets. On the Kentucky Street side it extends the whole block to Fifth Streot.

Degeription - Tho Auditorim was comploted in 1929 as amorial to the Soldiers, Sallors, and arines who served the Nation in World War I. The architecture is classio Greek and shows the Egsptian origin from which Grook arehitecture was derived. The bullding 18 gray, massive, and permanent in appearance as should be for a momorial. The copper dome is supported by four arohes with four orgen openings. There are ton Dorle colvme at the Fourth Street slde and the four outer doors are bronze.

The ground floor of the Auditoriun comprises: foyer, and offlces, the horseshoo, the auditorium, stage, and dressing rooms, guest room, and stairs to the museum below.

On the second floor The Flag Room, of speclal Interost to the public, runs helf the length of the bullaing on the Eentucky Stroet side.

Ulsiting Arrangements - An appointment with ur. W. H. Camp must be mede a week in advarce. A class of around thirty-fire can be accomodated and a gulde 18 provided.

III Clubs and Museums

A The Filson club 
Lecation -- 118 West Breckinridge

Description -- The Filson club is a historical society organized on May 15,1884 , under Colonel Reuben $T$. Durrett's leadership. The Club was named in honor of John F1lsan, a ploneer and surveyor, who published an important history of Kentucky.

This Club is housed in a red brick bullaing built in 1929. A large collection of historical books, original plctures of pioneere and old forts, books, diaries, manuscripts, and old records of meny carly Loulsville familles are found in the reading rocm on the main floor.

In the museum are found many relics of early ploneere, a collection of flags, and many old guns.

Vlexting Arrangemente -- It is necessary to make an appointment wth oither Hies Brelyn Dale or Hiss Luda KInkead, the guldes, as their hours vary. A group of no larger than twenty-five can be conducted through the Club. B J. B. Speed Memorial Museum Lecation -- 2035 South Thind Street Description -- This white stane builaing was given to Louisville in 1927 by MrB. James B. Speed as anument to her busband. Here one may see beautiful Baglish, Gorman, and Austrian porcelain and pottery, ploneer relics, antique musical instruments, perwanent and loaned art exhibita, and cecorated chests and furniture. 
Vialting Arrangements - It is nocessary to make an appointment, which can be done by calling the offloe (Kagnolla 4039). The ontire class may cone to the muserm and gulde is provided.

Houre. Monday -- Closed. Tuesday through Saturday the hours are 10:00 A.H. to 4:00 P.M. Sunday - 2:00 P.H. to $6: 00$ P.

The Confederate Monument may 2180 be seen on this trip. (See description below).

c Main Library Muserm

Soe Ioutsville Public Library above.

$$
\begin{aligned}
& \text { IV Industries } \\
& \text { A Ballard Wills }
\end{aligned}
$$

Location - 912 Bast Broadway

Desoription -- Largest winter meat flour w111

Visiting Arrangements -- Only high school age students are permitted as too dangerous for younger chllaren with present equiprent. Later the mill expects to have safer equipment and then younger children might come to visit.

$$
\begin{gathered}
\text { B Bradford Woolen Mills } \\
\text { (American Woolon Co.. Inc.) } \\
\text { Loontion - } 1034 \text { Bast Oak Street } \\
\text { Description - At the mill the chlldren may flrst }
\end{gathered}
$$
see the wool being oleaned of all loose dirt, straw, and 
burxs. Then the wool is sent down a chute to the first floor where there are large vats in whlch the wool is wased and rinsed unt11 white, and then dried by a hot air machine.

By means of foreed air, a machine sends the cleen wool to the second floor to be combed. Several meclines with big cylinders and combs take out all the tangles unt11 the vool 18 soft and Pine.

Several eloctrical machines spin this soft rool into finer and finer jam. At last, it is spun into fine throad which is wrapped into skoins. Each skein is tiod, marixod If to be bleached, and inspected for knots and bad thread. At the Eround floor the skelna, belng prepared for ahipping, aro tristod and then packed into paper bags that are tightly soaled. These ero placed in burlap secks, and properly taged for shlpment.

V1siting Amragemente - Because of the dengors of the mackinery and belts, only five to ten children, accompanied by adults, may visit if an appointment is made wib Wr. C. Comett, who w111 axrange for a Euide. C Puritan Cordage Mi11s

Locat1on - 1205 washington Description - Hero one might see the oporetion of raw cotton from the bales spun into yarn. Visiting Arrangements - To visit an appointment 
must be made with $\mathrm{Mr}$. $R$. A. Seger who w111 see that a guide is provided. Hot more than ten chlldren may visit at one time.

D Coca Cola Botting Company

Location - 1661 West H111

Description -. In this beautiful modem bullding the visitor may see the complete process of botting the coca cola. From the platform where they are mlosded, the bottIes go to the basement to bo started in the washer. Still being washed they come to the firat floor, and then they are fllled with syrup that comes from the second floor aymu room by pipes. After the bottles are filled they are loaded on trueks.

Visiting Axrengements - An appolntment mist bo made wth 1 1ss Lary Brucker. Any size group may visit and a gulde w111 be provided.

$$
\begin{aligned}
& \text { E Ford lotor Company } \\
& \text { Loegtion - } 1400 \text { Weatex Partway } \\
& \text { Deseription - At the plant the chilaron way see }
\end{aligned}
$$
cars completely assembled.

$$
\text { Vis1ting Arrangements - A large class mey visit as }
$$
soveral guldes are erailablo. It is necessary to mako an appointmont. Write to Plant Protection Offlee giving the day. time, and the number to come. 


\section{F Bakerles}

1. Honey Krust Bakery

\section{5}

Location -- 1455 South Seventh Street

Description -- Woon is the hour at which the largest number of processes can be seen in operation. The dough is cut into loaves at midnight.

There are two bakings daily. Milk used in the afternoon baking is from that morning's milking. It is fresher when used than the milk that comes to eity homes from dairy plants. Noticeable features of the bakery are size and efflciency of the machinery used, the whiteness of the bakers' costumes, caps, gloves; the absence of duet in all parte of the plant. The baking and wrapping rooms are very warn.

The bakery has its own stables, garage, and railway siding.

From 27,000 to 30,000 loaves are baked daily. Each process is cared for by means of machinery.

Three floors are used by the bakery. The first place shown to visitors is a laboratory in which all proposed materials are tested before being accepted for purchase. There is an electrically chilled refrigerator room in which are kept Vitamin D, honey, yoast, cream. Vitamin D is bought at a laboratory and comes in tubes. Yeast comes in blocke the size of pound of butter. Clover honey is brought from the Honey krust Farr, but the bakery usee three carloads of honey year, so sage honey is brought from Kanses and orange blossom honey from callfornia. Honey is used in preference to ougar by this bakery. The milk brought from the Honey Krust Fari is frum Jersey cowe.

Visitors are welcone at the Honey Krust Farw, Shelby County, Kentucky.

Buckets of selt stand near the mixer ready

\footnotetext{
Ibid., pp. 17-18.
} 
for uae.

The Ingrediente are poured into the mixere from alides in the third floor. They are solentifically coled and walghed. There are three hube hoppers frat which plour is sifted into the mixors and thre large tanks to relaase the lee wher with which all vixine is done.

The enormous blades of the mixer shoot back and forth and lnoed the dough much as oundy cotton is pulled on hooks.

The doore of the nixere open to dump the knesded mass into steel troughs twe lve feet long. The troughe are rolled into the dough coom for ferwentidion.

The doush is out and the dough balls anoped into loaves by uacilirery. (Tiests of pacs. ench fllled with loaf, pase alons to the lorg bteel chatna in the final proofer which 1. always woving.') The loaves rise for fortyfive minutes in an lnclosed roon, tken conveyore cerry the pand of dough to the oven. A baker starids nekx the oven. He wiks down the line of pans with a sharp knife in his hard. f deft cut puts into eact 2oaf of dough the Foney Krust oplit. The oven is a hundred feet lono. The pans of loaves travel slowly through it for haif an hour. When they energe, the bread is batad, brown and fragrant. $h$ baker turns the hot loaves into a corveyor which carries then into the next rook. When they are cool, they are sliced and wraped by baclinery.

The rapping has the uncanny precieion of a robot at work. The loa 1 io trrust againet the wrapper wich folds around it. Then it passes over a hot section wich relts the waxed paper and causes it to setic later an outer wrepper is put on ach losf.

The loaves are placed in weeled trucks of nine stelves and are ready for packing and aistribution.

In the clangor and crash of wachinery, white, costumed bakers are engaged in molding loured dough into many varieties of orest and rells. They appear to work silently and with deliberate aureness. Thoy are guardiaris ot a vitachine that reede a ofty." 
Viefting Arrangements - Iarge class may visit the bekery. Make appointment with 1 . Miller who will see that a guide is provided.

2. Donaldson Baking Company

Location - 1321 West Hill

Description -- The process of bread making may be seen here.

Ylsiting Arrangements -- Appointment may be me with Mr. B. D. Wilkins, The whole class may visit, but muat be accompanied by several edults. A guide 18 provided.

$$
\text { a Rerineries }
$$

1. Aetna 011 Company

Looation - Algonquin Parkway

Deseription -- The visitor mey see the various phases of crude 011 being refined into gasoline and other products as well as the means of transportation used.

Yisiting Arrengements -- Only a very small group may visit the rofinery. An appointment must be mado with Mr. Van Buren. The services of a gulde will be provided.

2. Loulavilie Rerining Company

Looation - 1300 Southwestern Parkway

Deseription -- Here the chlldren may see the crude 011 refined into gasoline and other products.

Vialting Arrangements -- An appointment with ur. Loudermill, the superintendent, is necessary. Only a small 
group may visit as too dangerous for a large group. A gulde is avallable.

3. Stoll 011 Company

Loeat1on - 1815 River Road

Descrintion - Here crude oll ia rofined into gaso-

Iine and other producta.

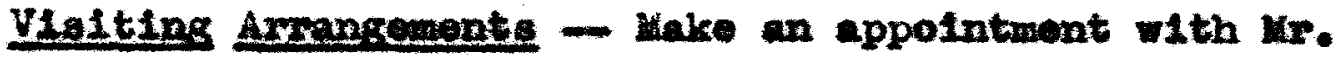
J. T. Crowdus on Mr. J. W. Kittner to bring only a mail group to the refinery.

\section{基 Datries}

1. Sealtest Incorporated

Location - 431 West Oak

Description - "Pirst, you w111 be shown the reeoifing platiorms, where the milk which the refrigerated trueks have brought in from the farms is weighed and sampled for laboratory tosting. After the milk has been wolghed and sampled, the cons are lmodiately omptied. They are then washed, sterilised, and returned to the trucks wich are waltins to take them back to the farmers."

"Your guide will next take you into the room where you will find the big cooler thich chills the milk at once to a temperature below forty degrees."

"In Imagination you will now follow on 1ts route through the plant the milk which has so lately been sampled, tested and chilled. It flows into insulated, stainless, steol holding tanks where it awalts filtration and pasteurization. Piltration is accomplished by passing the millk through closely woven cotton - similar to surgeon's cotton. In order to k111 all germs, the milk is then pasteurlzed. This is accompilshed by heating it to 142 dogrees, holding it there for thirty minutes, or 160 degrees for five minutes, and then cooling 
ing it to below forty degrees. The milk is then ready to be bottled. Before being filled, each bottle is soaked in hot alkall, powerbrushed, and thoroughly rinsed in the bottle washer - fifteen minutes of modern washing and oterilizing. After wasing, the bottles are automaticaliy filled and capped. Vacuum fillers assure accuracy and ellainate the filling of cracked or chipped bottles. The milk is now ready to be delivered to the customers. After showing you the giant freezers in which ice cream is made, your guide will take you into the auditorium where the child ren may be comfortably seated while he answers the questions which they will be aure to be eager to ask him.

This is a very interesting trip and the children are sure to come away with clearer and better understanding of the care that is being exercised in order that the people of Loulsvilie may be supplied it th pure milk." 6

Vieiting Arrangements -- An entire class may visit. An appointment must be made with Mr. Vic O'Daniel or Mr. Tom scott.

2. Fenley's Model Dairy

Locrition -- 606 West Hill

Description -- A 11 plant but one may see the milk prepared for the consumer.

Vlaiting Arrangements -- Only a comittee may visit the plant as it is ascil. The appointwent must be made with Mr. Fenley or Mr. F. K. Dickerson.

\section{Furniture and Plywood}

1. Mengel Company

$\overline{{ }^{6} \text { Ibid., pp. 18-19. }}$


Looation - mise are three plants: Furniture Division, 2300 South Fourth Stroot; Plywocd Diviston, 2300 South Fourth Strest; Corrugated Box Divialon, IIII Zane Avenue.

Description and Ylsiting. Arrangements - (I) The Pumpture pivision rlant of hengel's may be visitod by ten chllaren making an appolntrant with Mr. H. E. Logsdon. A gulde w112 be provided. Here the students might see the cutting of venesr, plywood, doors, and the cutting of big logs of mahogany. Mis 13 the most interesting of the three plants for visiting.

(2) Plywood Division does not pernit any chlldren as too dangerous.

(3) Cormugated Box Division - An appointwent must be made with Mr. Albert Ahlors for a olass, in accompany with three or four adults, to visit. The best hours are from 8:00 A.M. to 3:00 P.M. Mr. Ahlers Indicated that there wasn't too much to see also that too many classes cannot be permitted.

(4) General PIywood Colporation

Location -- 3131 post Valnut Strost

Description -- The chllaren may see the plywood being made. Samples are sometines provided for the group. An appointment must be made with is. 2 . O. Prloe. plant superintendent, glving the age of the group and the 
howr desiring to come. The services of a galde are provided. A committeo of six to ton chllaren are preferred for safoty reasons.

$$
\text { I Farn Machinery }
$$

1. International Harvester Company

Loeation -- Crittondon Drive

Description -- Cultivators, plows, and other farm machinery are made here.

Vialting Arrengemente -- At the present time no ohildren under twelve years of age may visit. Appolntmonts are made with Ur. A. B. Mecreary.

2. B. F. Avery and Sons Company

Location - 1721 Seventh Stroet Roed

Degaription - Chlldren might see the farm mochinery as oultivators, plows, tractors, and others being mado. Furnaces present a safety hazard.

Visiting Arrengementa -- Ten children vist at one time. The services of gulde are avallable. For appointment oontect Mr. J. O. Lawrence.

I Loulaville Soybean Products Corporation

Loeation - 1361 South Fifteon Stroet

Desaription - Here the soybean way be seen ground Into meal and oll.

The trip through the plant takes about a half hour to three quarters of an hour. The best time to visit is in 
October and November. In September the plant shuts down. Vialting Arrangementis -- A anall group may go through the plant. For appointment contact Mr. H. A. Miller.

L Reynolds Metals Company

Lecention -- 2000 South Winth Street

Description -- The most interesting plant for children to visit is the Utensil Divialon, Plant No. 14.

Vieiting Amperesente -- Por an appointment contact Mr. Beard, Publlc Relations, at Plant No. 14. Only a umell group of ten may vieit at one tine. The cervices of a gulde are provided.

\section{Paper Company}

Acme Paper stock Company

Leantion - 141 Horth Second Street

Daseription -- Just a warehouse where children may only see kinds of paper in stock. All paper companies here in Loulaville are just jobbera.

Yiliting Arongenente -- About twenty children my visit at one time 15 en appointment is made with Mr. Reanick. 4 American Radiator and Standard Sanitary Corporation

Leeation -- 1541 south Soventh Street Dencription -- At the factory plumbing elxtures are made.

Vieiting Arrengemente -- An appointment mat be made 
a week In advance wth Ur. R. A. Vollmer for a mall group of children to visit. Sometimes the authorities grant permission for vieiting and cometimes, thoy do not.

Q Armour Creamertes

Lecation - 333 Eyrne

Description -- Here butter way be seen charned, poultry dresed and frosen, and egge sraded.

Vifiting Armoncemente -- Mr. Charles Williams eays that no children may visit as dangerous and too noisy. They do hope to be able to have children come later.

\section{P Meat Packere}

1. Armour and Company

Lecetion -- 201 Eat Main Street

Deacription -- This company does not do their elaughtering here. The meat comes already dressed. Sausages are made and the children may see meat smoked.

Vialting Aprangenente -- For appointment contact Mr. H. K. Nans, who will oee that a guide is provided. Only fifteen children at one time may vielt.

2. mart Packing Company

Lecation -- 1202 Story Avenue

Deseription - Hore the childron might see the animals killed, and cut, sausages made, and meat moked.

Visiting Arrangement. -- Fifteen to twenty children may visit if an appointmont is made a woek in advance with 
Ur. L. J. Llebert.

3. Henry Flscher Packing Company

Location - 1862 Mellwood

Doseription -.. On Thesdays, Thursdays, and Fridays children may seo the killing of the animals. On Hondays, Fednesdays, Truraday 8 , and Friday the chlldren may soo the outting process.

Vialting Arrengemente -- The visiting hours are 8:00 A.M. to 1:00 F.M. From lionday through Friday. An appointment must be made a woek in advance with Hr. John Fumphrey. A gulde is provided. An entire class visit at one time.

4. Llarer Provision Company

Location - 210 Any Avenue

Visiting Arrangementa -- No visiting is permitted as too dangerous.

5. Louisville Frovision Company. Ine.

Location - 914 East harket

Deacription -- The killing of the animals may be seen and also the slleing of the bacon.

Viaiting Arrangements -- Only a couplo of days notice must be given. An appointment way be made with $\mathrm{x}^{\mathrm{r}}$. Faul Rose. Twenty chllaren may be accomodated but two or tiree adults must acconpany them. A gulde is provided. Around $10: 00 \mathrm{~A}$. A. Is the best hour to visit. In the afternoon not 
much to see.

6. C. F. Visaman and Company

Location -- 117 Blekel

Daseription - The killing and cutting may be seen.

Vielting Arrengements -- A clase of around thirty children might visit 15 a week's notice is given. Make appointment wth Mr. F. P. Able.

Q Bourbon Stock Yards

Location -- 1048 Bast Main Street

Description -- The yards recelved their name from the Bourbon House, a drover's tavern, which stood on this site in the early days. At the stockyards the chilaren may see the animals weighed and sold. This is rather unique as there is no set price on the merchandise when the animal is sent here by the owner to sell.

Viaiting Amengemente - A class of thirty to thirtyfive children, ten and eleven years of age, may visit if an appointment is made wth Mr. Skeffington. A guide will be provided.

$$
\begin{aligned}
& \text { B Hadley Pottery } \\
& \text { Lecation - } 1570 \text { story } \\
& \text { Deecription -- The children may see the pottery being }
\end{aligned}
$$
mede.

V1alting Ampangenente -- An appointment may be made by just calling the office. Visiting hours are 3:30 P.M. - 
4:30 P.M. on Friday. Fifteen to twenty children way vilt. I Pobacco Warehouses

1. Seventh Street Road Warehouse

Lecstion -- Seventh Street Road

Dasaription -- Children may see the tobacco being

sold and bought.

Vteiting Axsongements -- The whole class may vialt if appointment is made with Mr. J. M. Lamkin. A gulde is provided. Nothing to see except during the tobacco season.

2. Burley Tobacco Warehouse

Leestion -- 1520 Durret Lane

Dencriotion -- Here the class may see the buylng and selling of tobacco.

Visiting Aprengemente -- The entire clase may visit if appointment is made with Mr. Henry Bell. A guide is provided.

3. Loulaville Loose Leaf Tobecco Warehouse Company Lecation -- Seventh Street Road

Deacrintion -- During the tobacco season the children way see the buylng and selling of tobscco.

Yiriting Arrengementa - The whole clees way vielt If appointment 18 made with Mr. Batty. A guide is provided.

I Tobacco Manufacturers

1. Brown and Williamson Company 
Lecation -- 1600 West Hill

Deseription -- The children may see the eigarette beling marufactured.

Viaiting Arrengegents -- No appointment is necessary as the company has a receptiontst in the office who may act as a guide for an entire class.

2. American Tobacco Campany

No children are peraitted against policy. Would have to have a permission frow New York.

3. Liggett, and Myers Tobacco Cospany

Lecation -- 2418 Wegt Main Street

Only storage space, nothing for children to see.

4. P. Loriliard Company

Lecation -- 3029 Michigan Drive

Ho visiting perritted.

V Statues and Monuments

A The Castleman Monument

Lecation -- Thls monument atands in the big circle made by the intersection of Cherokee Parkway and Cherokee Road.

Description -- Made of bronze and mounted on a tone base, it showe General John Breckenridge Castleman mounted on his famour saddle mare, carolina. Funds for this monument, which cost $\$ 15,000$, were contributed by Loulsvilie, Kentucky, and the South; and the statue was unveiled on November 8, 1913. General Caetleman is thus one of the few men in whose honor a atatue was erected during his Iifetime. The 
monument was designed by $R$, Hinton Perry, a noted New York sculptor. Mr. Perry came to Louisville and spent two months at General Castleman's home, studying the subject and preparing a plaster-of-Paris model. General Castieman was lover of horses and of the many beautiful ones which his stables housed, h1s favorite was the jet black saddie mare, Caroline, most famed descondant of the great Cheater Dare. Goneral Castleman was borm in Fayetto County, Kentucky, In 1842. When a boy of nineteen, he joined the Confederate Arry under General John H. Morgan and later becase major. Ho was sent north to attempt to rescue some prisoners of the South who were held in northern prisons. While on thla mission, he was captured as a spy and, though hls 11 fo was spared by President Lincoln, he ras kopt in prison in Indianapolis. Indlana, from September 1864 to July 1865. Ho was then roleased upon condition that he would never roturn to this country. After remalning in Europe as an exile unt11 1866, he was pernitted to return howe. At that time, he was 24 years of age. Later he served his country as Adjutant General of the State militia and Brigedier General in the American Arzy during the Spanish-American Var.

"But it is because of the services rendered by him as private citizen that Coneral Castleman $1 \mathrm{~s}$ best loved by the people of Louleville; and it is as Father of the Park System of Loulsville' that he is best kmown here. He was olght times elocted as amber of the Park Board and served as its president for nearly twonty years. It is sald that he took os much interest in the parks as if he ownod thom himself. The extension of Cherokeo Park and of Shawnee Park, the enlargement of Jacob's Park to Include 600 Instead of 300 acros, and the purchase of Shelby Park are due to his offorts and Influences: whilo he personally gave both money and land to Improve and onlarge parks and playgrounds. Thet the people of Loulsvillo have Lastem Parkway as a thoroughrare is due entirely to the offorts of General castleman. He donated for that 
purpose a otrip of land through Castleton, his property, and gave $\$ 5,000$ toward the bullaing of the road. He also gave ten acres of beautiful woodiand as an addition to Tyler Park."

Mr. Ernest C. Kettig, who for twenty-five years was hillself connected with the parks as ouperintendent, sayss 'It was General Castleman's habit to arise every morning at 4 o'clock and mount his famous saddie mare, carolina, for a tour of inspection. He would ride about and take notice of what was needed and by $70^{\prime}$ clock he would be familiar with the condition of the places he had visited and would telephone me regularly at that time to discuss the work of the day. He would know to the minutest detail exactly what repeirs should be made curling the day. Agmin in the afternoon, he went over the places to see if the work had been done properly. "I - Acting upan ordere from the Generel, I went often to the woods near Loulevilie and brought back thoueands of dogwood or redbud shrube, maple, oak, poplar and gum trees. These we raiged in the nurseries in Shamee Park and later set them out in the parke and along the streets without a penny of cost to the citizens of Loulev111.. We gathered in this way more than 100,000 trees. On ane street, we set out oake, on another maples, on another gum trees, and still othere sycamores. On Southern Parkway, for a stretch of three miles, we set out four rowe of trees, thus making twelve mlles of trees. Wo also set out miles of trees on Eastern Parkway. All of this wa done under Generel cestleman's direction and without cost to the people. Many of the magnificent ohade trees now in Shawnee Park were raised from nuts planted in the shawnes nureeries at the suggestion of the General.'

General Castieman died on May 23, 1918, and at the hour of his funerel, chllaren were acked to cease all playing in the parks for five minutes lout of reapect for him who made public playgrounds possible in Loulsvilie." 
"How appropriately has the equestrian statue of General Castloman been placed at the entance to Cherokes Park where it seems to be keeping watch over the General's splendid contribution to the beauty of our city." 7

B The Confederate Monument

Location -- Third and Shlpp Streoto

Deseription -- This harisome shaft was given to the clty by the Confederate Uonument Association of the United Daughters of the confederacy. The monument, unvelled on June 29, 1895, was made in Italy under the supervision of the Huldoon Konument Company.

Visiting Arrangements -- None noed to be mede. The Speed Huserm may be visited also on this trip. (Soe Speed Huseum for visiting hours).

c Daniel Boone Monument

Location - Located on a eliff in Cheroke Park. Deseription -- This monument is the work of a Loulsv111e woman, M1ss EnId Yandell. The bronze statue was made at the request of $M r$. C. C. Blokel who gave it to the park commission. It was formally unvelled and given to the olty in 1906. The face was taken from portralts of Boone at the F1Ison Club, and gun and skin cep rere copled from his actual ones. A stone model of the statue is found at Foster School.

Ibld. pp. 23-24. 
It 18 generally conceded to be the most accurate representation of the Kentucky woodsman that could be de8 pleted.

Visting Arrangements -- Hone needed

D Clark's Grave

Location - Ceve H111 Cemetery

Visiting Arrangements -- Men visiting atop by the

Cave Hill Cemetery office for information. No gulde is provided. The whole oless may visit.

E Jefferson Monument

Location -- In front of the Court House

Description - See "Court House" for description

of the monument.

E Locust Grove

Loeation - Blankenbaker Lane

Deseription -- The two and one half story brick

atructure of Georgion style was the home of George $\mathrm{R}$. Clark's sister, Hrs. W. C. Croghan. At her home Clark, an Invalid, spent his last remaining days of bittemess of the Ingratitude of the nation until he died on Fobruary 13, 1818.

V1siting Arrengements -- Can only be seen from the outside.

8

Ibid., p. 22 . 
G Mulberry Hill

(The Howe of Clark's Father)

Lecation -- Beargrass Creek near Poplar Level Road. This is near Fincastle Helghts, the government housing project.

Deseription -- In 1784 George R. Clark's father, John Clark, bullt a house here. In 1890 the house was abandoned and in 1917 it was torn down. The city received the land as a glft later and $1 \mathrm{t}$ is known as the George Rogere Clark Park.

\section{E Henry Clay Statue}

Lecation -- In the rotunda of the court House on Jeffergon Street between Fifth and Sixth Streets.

Deseription -- See the description above under the heading "Court House."

I Abrahan Lincoln Statue

Location -- On the west lawn of the Main Public Library at Fourth and York.

Deseription - See the Library description above. $I$ Fort Neleon

lecation -- Seventh and Main Streets Degcription -- on the site of old Fort Helson a seven foot slab of Georgia granite monument bearing a bronze tablet was erected in 1912 by the Colonial Dames of America in the stete of Kentucky. It bears this inscription: 


\begin{abstract}
To conmemorate the establishment of the Town of Loulsvil10, 1780. On this site stood Fort Nelson, built in 1782 under the direction of George Rogers Clark efter the expedition which geve to the country the greet Northwest." 9
\end{abstract}

Fort Nelson erected in 1782 extended from Sixth to Eighth street with fronting on Main Street and reached back toward the river. The stockade was surrounded by a ditch olght foot wide. The fort was named in honor of General Nelson the third govenor of Virginia.

Visiting Arrangements - None nocessary.

I Prealont Zachary Taylor's Home and Homument Location - A few miles from Loulsvilio by way of Brownsboro Road and Blankenbaker Lane.

Description - The monument and burlal ground of President Taylor, famous American soldier and the twelfth President of the United States, 1s located on the old homestead of the Taylor family. This is now a national shrine.

As a result of Congressional appropriation, the monument wes erected in the old burlal ground. On top of a thirty-four foot shaft of grenite is atatue of ceneral Taylor.

In this national cemetery enjone who has served in the army or navy mey be burled.

Vigiting Arrangementa -- No appolntment noed to bo

Iold., p. 22 . 
mode. There is no gulde service.

I Saslbach Fotel Paintings

Looation -- Soelbach Hotel Fourth and valnut Streots Description - In the lobby of the hotel ney be

found eight palntings honoring General George Rogers Clark.

Visiting Arrangements -- Hone necessam.

L Marker on Court House Honoring Clark

Location -- On the right side of the entrance to the Gourt House.

Desaription - See Court House description above.

vI Transportation and Comunication

A Bowman Fleid Almoort

Location -- The afrport is located in the eastern section of Loulsville just outside the city linits. It Is about five miles southeast of Loulsville on the Taylorsville Road.

Deseription -- This municipal alrport was named for Mr. A. H. Bowman, a cltizen of Loulgville, who did so much to promote interest in the alrport.

The Adninistration Bullaing at the alrport houses the offices of the Commander of the Alrport, the United States weather Bureau, a restaurant, and a walting room. The Alrport's hangars are flraproof and moderm in overy way. During the war the Army Alf Force bullt barracks on the edge of the fleld for men stationed there. 
These are now used for homes.

Each alrport has its own aignal light so that aviators may know what alrport they are approaching. The signal for Bownan Field is dot-dash-dot and the color of the light is green. There is also a largo seareh light that sends a bean for several miles in all directions, giving planes a warning of the field quite a distance away from 1 . The American, T. W. A.. and Eastorn Afr ilnes have planes coming into Loulaville from all sections of our country.

Hundreds of people visit the Alrport weekly. Commereial pilots are always thore to give those who wish it a "bird"s eje view" of Loulsvilie.

Visiting Axrengements - The ontire class may visit if an appointmont is made with Mr. Henry P. Julliard, Administration Bullaing. Bowan Flald. A guide will bo provided.

B A Branch relephone orfice

Location - Thore are nine branch offices such as the Magnolla, Highland, Shawnes, Jackson and others.

Description -- A branch office is an interesting place to visit as the children see the operator roeoling calls and the connections she makes. The operator's hoadgear, the switehboard, and the various operations in connoeting callers is so faseinating. 
Wialting Arrangements -- Only a comittee of ten children may visit a branch telephone office. Appointments mast be made with Mr. H. W. Herr, Commercial Department, Office Manager. Mr Herr will arrange with the superintendent of the branch for a gulde.

f Courler-Journal and Loulaville Times Lecation -- 300 West Liberty

Description -- This is a very old building and for that reason the encouragement of visitors lo not made. Then they move to their new hoadquarters at S1xth and Broadwas, the Courier-Journal hopes to have many vialtors. This will be an interesting trip for chlldren as they wll see the necessary operations for printing the daily paper that comes to their homes.

Vialting Axrongemente -- About ten to twelve children may vieit if they are accompanied by two or three adults. For appointments contact Ules Alma Floher of the Personnel Department, who w11l arrange for a guide.

D Railroad Station:

1. Unton Station

Lecation -- Between Tonth and Eleventh Streete on Broadway

Dencription -- Inside the gray etone building there is a long walting room with many benches. In one corner of the room is the Information Bureau. On the east side of 
this row are tloket windows, and on the west, are stande where candy and magnzines are sold. Above the room is the beautiful stained glase celling and lacy iron railing around the high belcony, whlch is on three sldes of the rocu. The station also has a nice dining room.

At the back of the station 1 s the huge train shed where trains back into the station. Several trains come Into this station auch as the Loulsville and reehville Railroad, the Monon, and the Pennoylvanla.

Vialting Amongemente - The ohlidren may violt the station at any time, but for a gulde to be furnished for an entire class an appointment must be made with Ur. G. U. Yager, General Passenger Agent at $L$ office, Ninth and Broadway.

2. Central station

Loegtion -- Soventh and River

Denceiption -- This atation is older, amaller, and Iess nodern than the Union Station. However, wany trains dally enter and dopart from its shed, bringing passengers and freight from the Forth and South. The Baltimore and Ohfo trains, the Chesapeake and Ohio Railway, the BIg Four System, the Illinois Central, and the Southern Rallway Syoten use this station.

On a trip to the etation the children might also visit the stone marking the alte of old Fort Helson at 
Seventh and Main.

V1siting Arrangements -- For arrangements to visit this station, contact Mr. J. R. Soott of the Chesapeake and Ohlo Rallroad, Starks Bullalng Offlco.

E Rallroad Yards

Location - The Highlend Park Yards are in south Loutavilie and the Baxter Station is in east Loulaville.

Desertptlon - There the children may soe the tralns being awitehed.

Visiting Arrangements -- No appolntment is necossary and there w1Il be no guide furnishod. The children oannot go into the jards but just $200 \mathrm{k}$ down at them.

I Truak Depota

1. Haneock Truok Lines

Loeetion - 131 Horth Tenth Street

Deseription - Small depot, not moh to see.

Visiting Arrangements - Call offlce for appointment.

2. Huber and Huber Motor Hxpress, Ine.

Location -- 970 South Elghth Street

Deaoription - Large truak 11ne.

Visiting Arrangements - Wo chlldren are permitted

to visit for safety rousons.

3. Kentucky Indiana Track TerminaI

Location - 1227 Garland

Deseription -- The freight coming in and leaving 
the depot can be seen.

Vioiting Amengements -- The entire class way visit if an appointment is made with the office. A guide will be provided.

4. Silver Fleet Motor Express, Inc.

Lecation -- 216 Pearl Street

Description -- A large motor express company with moh frefght coming in and going out at it dock.

Viating Amengement -- Fifteen to twenty children may visit if an appointment is made with Mr. 0 . L. Doud.

5. Hoover Motor Express Co., Inc.

Location - 1224 Rowan Avenue

Description -- There isn't much to see as the dock is $\operatorname{sma} 12$.

Vis1ting Amangements -- Make an appointment at the office.

$$
\text { G Radio Stationa }
$$

1. A V E Ine.

Loeation -- 334 East Broadway

Description - Children may see the music librery, the studio, the news roon through the window, and the control room when empty.

Viniting Arrangenents -- The entire clase may visit, but it is beat to come when a program is on sultable for children. Therefore, it is necessary to male an appoint- 
ment with Mr. E. W. Leake.

2. W If C Radio Broadcasting Station

Locatien -- Kentucky Home Life Building

Description -- The studio is not so large and not

too much to see. Best to corie to the station when a progran ia scheduled for children.

Visiting Axrangements -- Twenty-five children may visit at one time if an appaintment is mid with the office.

3. $I N N$

Location -- Earle Hotel

Descriotion - The studio is very small, however, they are glad to have chllaren visit.

Visiting Arrangemente -- The entire class may visit, but would have to be divided into groups going through. It is best that about fifteen at a time visit the station. As an appointwent is needed, contact Mr. B. A. Kallay.

4. HA S

Location -- 300 West Liberty

Description -- Visitore are welcome. Studio not very large.

Visiting Arrangements -- The entire class may visit but an appointment must be de with Miss Calhoun, Personnel Department, Courier-Journal. A guide will be provided. II Greyhound Bus Station

Location -- Fifth and Broedway 
Degeription -- This station is a blue wodernistic building with a picture of the muning greyhound, the mark of this bus line, on its front.

Inside the building is comfortable wating room. On one side of this room are the ticket windows and a place to check the baggage. On the opposite side is a restaurant and a magazine stand. Around the roow there is a gallery upstairs where the rest roons and offices are located. outside, in the bsck, is a large shed where buses cane to unload or be loaded in the numbered lanes.

In part of the building there are stores such as a barber shop and an army store.

Visiting scrargewents -- The entire class may visit and a guide is provided. For an appointnent contact Mr. Porter. Adulte alist accompany the group.

\section{Along the Ohio River}

A The water Front

Description -- Loulsville is located on the Ohio River which furnishes her many advantages. As the Ohio is a navigable river and a tributary of the Mississippi, Louisville can trade by water in all directions. For this and other reasons, Loulsville has been spoken of as the "Gateway of the South."

Along tre water front at Second, Third, and Fourth streets may be seen the steeper Indiane shore on the op- 
posite side. Up the river is the Big Four Bridge and Towhead Island beyond. This 1sland was named because of the necessity of towing crafts upetrean through the rapids prior to the building of the canal.

At the foot of second street is the Municipel Bridge recently made toll free. Down at Fourteenth Street is the Pennoylvania Rallroad Bridge and Parther down at Thlrtieth is the Kentucky and Indiana Bridge. These two bridges connect Louf gville with New Albany.

The river front from first to sixth street is called the wharf, which is mostly paved with stone. Doats are moored to the wharf by cables or chains, which are hooked to big iron rings fastened in the stone paving. On the wharf, the freight is loaded and unloaded on boats.

The river front from Sixth street west narrows

until at seventh street it seens that the railroad trestles almost reach the water's odge.

V1qiting Arrangements -- None necescary.

B United States Cosst Guard Station

Locstion -- The station is moored to the wharf at Third and River.

Description -- This is the only inland Coast Guard Station in our country. This was necessary because of the nearness of the Falle to the clty. Establlshed about seventy years ago, this station cost about $\$ 3,500$. 
As the station is under the management of the Treasury Department, the Federal Government bears the annual cost of maintainiras the station. This includes the cost of keeping the houseboat or station painted and in repair, the cost of the signal lights, the telephone, the power boet used in rescuing, and the salaries and food supplies of the guards.

Day and zight, at least eight wen are on guard, and atchman, at all times, looks out frow the high tower.

Vislting Arcangements - A large group may visit but they will be divided into groups to be taken through the station by a guide. An appointoent is mado by calling the station, Jackson 4635 .

C Loulsville and Portland Canal

Lecetion -- Foot of Iwenty-seventh Street

Description - The canal is owned and operated by the

United States Govemment and is listed as United Ststes Locks NC. 41.
"From Fourth Street to the foot of the locks, there is a thirty-foot fall in the Fiver. On fifty feet of water, boats can go over the Falls, but when there is less water than that, the locks must be used. Thus, it is because of the Ohlo Falls that the Caral and Locks are necessary. The Canal begins at Sixth Street and ends at Thirtieth Street, extending a dis- tance of about two and one-half miles and be- ing 200 feet wide."
"There are two locks in the Canal -- one large lock which requires fifteen minutes to fill with water and a sasiler one which can be fill- ed in ten minutes. The locks are 110 feet wide. The longer one is 650 feet Iong and the smaller one is 350 feet in length." 
"The lango gates oloblng the locka are operated by a large pressure engine which is in the power house on the edge of the Canal. When boat coming down the pirer algnals to the lockman, the gauges are turned by him. This releases presurure on the huge iron gatea, closing tham so that the look mey be fllied to the corroet depth. A gauge shows wen the correct anount of water has been punped into the 10ck. The upper getes are openod ben the water in the locks has reached the miver level and the boat 1 allomed to go into the first 100k. While the boet is in the firet 100k, vater is being pruped into the second look and out of the first until the water in the two looke is on the seme level. The boet is then allowed to go out into the second 1ook. Then the water is slowly let out of the geoond loek until It is on a level ith the water in the lower river. The boat is then allowed to go out into the mives"

"If a boat is coming up the river, it comes Into the looks and the gates are closed. Tater is thon pumped in unt 11 the boat is ralsed thinty foet. If you ane on the boat. you can feol yourself gradually bolng ralsed up. up. upl then you are on a level with the water In the Canal. the gates ero opened and the boat goes on up the river." 10

Over hundred years ago, before the locks were construeted, boats coming up the rver landed at the foot of Thirty-ifth street. Theif frelght was transferred to wagona to be taken a distanoe of about throe miles up to Fourth Street, where the upper rver boats vere docked. Freight going down the river wat trencferwed the wame way. Stage ooaches wer used for transforring the passengers. There is no oharge today for lodking a bont through 
the Cana1.

Visiting Arrangements -- The entire class may visit if an appointment $1 \mathrm{~s}$ made wth $\operatorname{mr}$. P. B. Finglish, the head lockmaster. A guide will be furnished.

D The Fydro-Electric Plant

Location -- Twenty-sixth and Canal

Description - This plant was bullt at the cost of ten million dollars. Extending from the Kentucky shore, the power house is five hundred elgtt feet lone and fortyeeven feet wide. The building is built of steel and concrete to withstard the pressure of water.

In the generator room, which is fifty-eight feet high, there are eight generators, each with a capacity of ten thousand kilowatts. The power houge was so bullt that two additional generators my be installed when additional capacity is needed.

Visitors are taken down in the power house until they are thirty-eight feet under water. The large water wheel runner which is located at a still greater depth is connected with the elght generators by means of eight steel shafts alxty-one feet long and weighing trirty tors.

The theory of the plant's operation is that the river flowing through the base of the plant tums the large water

Ibid., pp. 7-8. 
wheels, thereby turning the shafts which are connected with the generators. This resulting in the generation of electric power. The flow of water through the wheels is controlled by gates. The operation of the plant depends upon the higher stage of the water above than below the plant. During floods the water level rises rapidly below the plant and the Fails are thus wiped out. As this reaves the force that turns the water wheels the plant must shut down. The electricity for the city is de at the Waterside station and the Central plant on Main Street.

The plant is controlled by means of a big switchboard in the generator room. Although two thousand men were required to construct the plant, less than ten men are needed to operate it because the nchinery is so conpact. These wen work in three shifts of eight hours.

Visiting Arrangements -- The entire class may visit If an appointment is made wh Mr. McCraig. The services of a guide are available.

\author{
VIII water Supply \\ A River Road Pumping Station \\ Location -- River Roed \\ Description -- At this station water is being pumped \\ from the Ohio River Into the pipes which carry it along \\ P1pe Line Lane and into the reservoir on Frankfort Avenue. \\ The electric punp now used is sald to be the largest south
}


of the Ohio River as it pumpe forty-two million gallons of water daily.

The water passes through a double screen to take out sticks, leaves, and small fish before leaving the pumping station.

E The Reservolr

Location -- North of Frankfort Avenue

Description -- Here at the reservoir the water may

be aeen dashing into the two huge basins, each holding fifty-five million gallons of water. The water dashes into the rorth basin, then passing through pipes into the south basin, and then out into the coagulation basin. The heaviest mud is left deposited in the big basins as it passes through. In the Coagulation Basin alum is added and as the water circulates around the five walls, the dirt and mud coagulate and sink to the bottor. From this basin the water passes into the filter plant. In the big filter the water passes through fire sand and gravel which removes all airt remaining in the water. After the water goes through the filter, ancther chemical is added to $\mathrm{klll}$ all germs. At the plant, there 16 minature filter in glass case. This shows exactly what happens to the water as it passes through, and the children have a clearer idea of the wethod of filtering the water and thus can make an experiment with minature fliters of their own. 
From the flitration plant, the water passes into an immense underground reservolf south of Frankfort Avenue between the Filtration Plant and the Crescent Hill pumping station. Its large ventilators may be seen from Frankfort Avenue.

c Crescent Hill Punping Station

Lacation -- Frankfort Avenue

Description -- The big pumps at this station pump the water from the underground reservoir into the pipes that lead into our homes. This $1 \mathrm{~s}$ done day and night. Vigiting Arrangements -- Arrangements to visit any of the above must be made at the Loulsville Weter Company, 435 South Third street, with Mr. Will1am I. Lovejoy.

\section{Miscelianeous}

4 United states Fiskery

Location - Gibson Lane, on the Ohto River, at the rear of the Kentucky Fair Grounds.

Description -- The fishery covers twenty acres of ground and has nine breeding ponds. During April through October there are five opecies of gave and fish there. These fish are sent to afferent streams, lakes, and ponds so that the fish may be of good species.

Viaiting frrangemente -- A large group of children may visit at any time. No appointment is necessary as there is always a guide. 
I Southern Baptiat Mheological Seminary

Lecation -- Grinstead Drive and Lexington Road

Description -- The Seminary is of Georgian Colonial

Style. As assembly hall, elassrooms, chapel, gymasium, library, dormitories, and \& zuseun are located here on the camplis.

The museur, is small but has some real interesting things from almost every country. Of the only two mumiles in the city, one is located here.

VIsiting Arrangements - The entire class may visit and be provided with a guide if an appointrient is made with ur. HeDonald.

C "The Old Kertucky Hone"

Location -- Kentucky State Fair Grounds

Description -- On these grounds there is a log cabin that is called "The $01 \mathrm{~d}$ Kentucky Home." It looks I1ke a real pioneer cebin with its old furniture.

Visiting crangements -- Only during the time of the Kentuwky State Fair may visitors see the cabin and its furniture. During the remainder of the year the furniture is stored in a safe place. 
CHAPTER $V$

THE ADINISTRATION OF A CLASS EXCURSION 
THE ADMINISTRATION OF A CLASS EXCURSION

I Preparation for an Exeursion

Introduction

Careful planning and preparation are vital to the success of an excuration. It way be a wate of time unless the exeureion is made a purposeful activity, preceded by careful planning, and followed by class study. The necesaury preparation procedures for an excursion are numerous and important. All exeursions mot be planned with the view not only as to what is to be accompllahed but also as to the manner in which the trip is to be made. Certain definite stepo taken by the teacher and the pupils for the evident auccess of the trip are necessary if 1 ts possibllities are to be realized. Some of these will be presented in this chapter.

\section{Advance Planning and Preparation on the Teachor's Part}

There are throe possiblitites in planning for an excursion weh as the following: (1) the teacher may do all the planning and axecuting; (2) the pupila may do the planning; or (3) the teacher and pupils may together plan the excursion. The latter is the best of the three as it capitalizes the Interests and experience of all taking part in the trip to make it successful. 
Certain amount of pereanal preparation and planning must be done by the tescher in alding her to work with the claos for a succesanu trip.

The following are augsestive steps for toecher proparation:

1. The teacher enstuate the advantages in taking the partioular excursion under consideration in order that as many contacts as possible may be utilized profitably. It must be certain that the trip is the best posaible means of attaining the desired ends.

2. In advance the teacher mast determine the purpose for which the journey is to be conducted or a posalble combination of purposes.

3. If ourvey data is available, it way be examined for materials that will develop correct concepte, and for situations in which activities may be organized to assiat pupils in developing desirable attitudes, hebits or akills.

4. The teacher should gain as mach information as possible through wide reading on the subject of the axcursion.

5. The teacher mat know and plan how pup1l interest may be Nurther atimulated, what materials to uso for a good background, and what proparatory activities children wight engage in. However stress on too many interesting aspecte of the excurelon may produce a certaln amount of bewilder- 
ment In pupils' minde as to what is the fundamentel purpose of the excuraion. Therefore, other interests must be held strictly aubsidiary to the main purposes.

6. The purpose of the trip aust be explained to parents. A few helpful mothers invited to accompany the group on the excursion has several advantages. If the group is large their assiatance is especially helpful. Otto points out the advantage of mothers present gives the teachor outside protection in case ome unfortunate happening chould occur. Also, few mothers after waking a trip and seeins the enthusiasm of the children are not converted. This becomes an asset for future trips. For the parents to be of assistance they wust know what is expected of them. Their presence at the preparatory class aesione is witee. 7. Before children are taken away from the school grounds it is essential that parents are notified and give their coneent. This permission should be in written form elther a signature to a letter from the parent or a mimeographed form furnished by the school. If the latter is uned, it way be made in the form of a waiver releasing the echool from responsibility to the pupil's eafety in addition to eranting the child permission to participate.

\footnotetext{
1

Henry J. Otto and Shirley A. Hamrin, Co-aurriaular Activities in Blenentar Schoole, New York: D. AppletonCentury Co., Inc., 1937, p. Z7.
} 
Thi form may state the purpose of the excursion, the way in which 1t 1 s to be taken, and the cost. The consent slips dated should be filed in the principal's offlce.

A sample form of a parent walver may be found in the Appendix.

If the parents are unfamiliar with an excursian progrem a form letter might be sent describing the progrem, explaining the method, giving some ldea of approximate cost, and of the need for making the school and personnel exempt from llability to injurles. Of course, it should be exphaelzed that every posaible precaution to insure the child's safety w1I be made but the school cannot assume further responstbility.

8. The teacher should make the following necessary arrengements:

(a) Secure clearance with the ochool authorities for the trip.

(b) Secure permission from the owner or representatives (superintendent or manager) of the place to visit. (c) Contact all persons whom the chlldren are to meet, interview, or hear, and explain the purpose of the trip. Arrange for the routine of the visit such as the time of arrival, meeting place, pictures, exhiblts, demonstrations, and other things that best meet the needs of the group. Dectde upon the possible or destrable cura- 
tion of the vieit, but be oure that ample time is allowed and adequate opporturity 1 s given for questions from the group. If the trip is long arrange for rest perlods and 1unch. Any possible dangerous aspects of the visit mat be thoroughly discussed. If there are some rlaks or hazards only a mall group may make the visit. If too many dengere the trip should not be made.

These necessery business arrengenents should be made by direct personal contset confirmed subeequently by letters setting down the arrangerente. Telephone contacts are not setiefactory at all in arranging a trip the first time. They are easy to make and equaliy easy to refuse. After a routine has been developed for a given excurelon through a nuber of repetitions, telephone discuselons or letters may be utilized.

Olsen aggests sending written reminders to all persons a day or two in advance of the trip.

9. Several days in advance the teacher ahould take the trip hereelf for fanlliarity with the situation, the best route, features, procedures to follow, necesenry refer-

\section{2}

Williem H. Burton, The Guldange of Iraying Activ1Heg, New Yorks D. Appleton-Century Co., Inc., IO44, p. 286.

3 Bdward G. Olsen, Sehool and Cormannity, How York: Prent1ce-Hall, Inc., 1045, p. 168 . 
enee material, longth of timo, bus stops, parking facilities, and what activities the exoursion would include. If the teacher has made the trip before, it showld be recent onough to propure the chlldren for 1t. Factors 11kely to interfere with the mooth running of the children's visit may porhap oome to 11ght during this preliminary trip and measures may be taken to minimize or remove them. The teachers oan also determine the best sequeney in whloh varlous centers may bo visited on one trip.

10. After the preliminary trip the teacher oan or ganize the materlal, plan the route, determino any neoessary stops, and prepare for eny antlelpated development. Ho one can forese everything that way develop but careful planning holps the ohlldren to get maxlmun use of the experience.

11. If several places are to be visited a dofinite time sohedule must be planned and adhered to rather close1y. A wise precaution is to place last eny plece or 1 tem from whloh it wight be diffleult to draw away the ahildren. Othervise it might be diffloult to koep to sohodule and include all that has been plamed.

12. The teacher must arrange for ang safeguards if needed such as speolal pollcomen at umusually busy corners. 13. Sowe arrangemont for provialab carfare or assistance needed by chlldren who cannot afford the expense 
has to be wade by the teacher.

14. The toecher may dovelop a printed gutal wheet to give woh excuration womber. This shoet in an open outIin fox should list the Itinorary. some signifieent problews for thought, guestions to bo enswored, and obser-

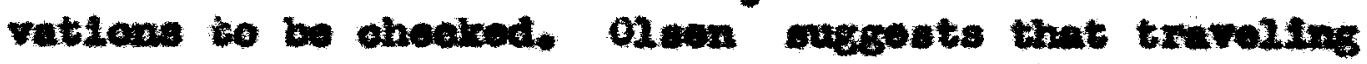
direations and names of speakers wth thelr toples be added to the gutde ahoet.

16. Whon it is nooessary to leave wavons bahtud beoaves of fallure to bxing consent allp of wa other nonwedioel ronson, the toucher mat make arrengoments and send him to another rock with an absignwent. So rar as feastbie the assigment hould be direotiy related to the

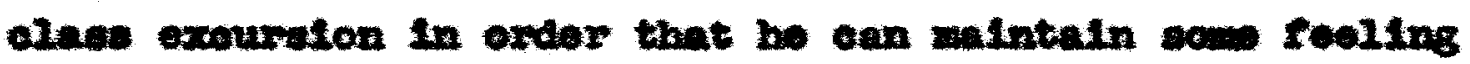
of charing in the ontorprise and oan contribute his part In arocediln group discusston. The newes of these pupile Iart bohtnd and thesr teagosary socm muber should be sont to the prinotpal.

16. It has boph megesed thit a travel list bo

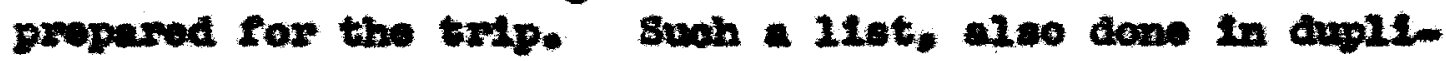
cate, proteota the gelwool by mabling the prinelpel to lonow who wat wore and when. It may also sowe as an at-

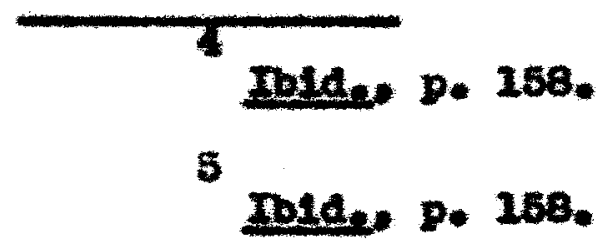


tendanes sheet on the trip for the teacher.

17. A rirst-ald kit way be carried on the trip.

18. If for any rengen tho achoduled oxouretion cannot be taken, the toecher ohould formally cancel the trip by notifyIng all pereone concemed as quickly as posalble. fupplanations may be nade then or soon arter by a letter.

The prooodure rollowed in doroloptng and ustng an excuration technique dependis upon the teacher"s skill in seleoting and oombining the proemdure best adapted to her noeds.

As a oumary four derinite steps as the following are inoluded in the teacher's greparation for an exoursion:

(1) Greatine In pupll. an owarenoss of the nood of the excourdion, and alding in olear, dof int te rormintion

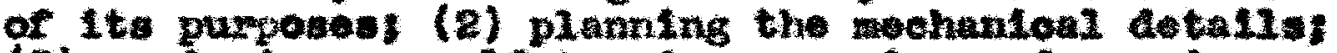

(3) equippinc oneale to give a malum of services and

(4) proparing the olass to dertve actuas of prorit.

Proparation on the Part of the Clase

Gnildron have to be enilghtened conerming tho gen-

- 1 1 10ala, purposes, and practices of the clase excuraton so that thoy w111 take the proper attitude toware the polloy and carry oupport and eccurate information to thelr paranta.

Excursions in wieh studenta asoum a large pert of

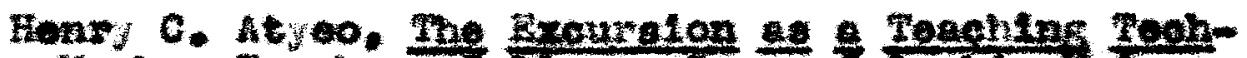

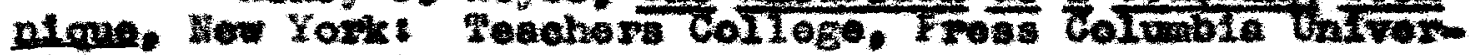
a1ty. 1959. p. 96. 
the responsiblitity for planning and management are not only more profitable but are much more amoothly carried out than those under the rigid direction of a teacher.

Through their group discussion the children see why the particular trip is important and how it relates to their class work.

The chsldren are also given an opportunity to develop pride in their school through their careful planning.

Plans must not be too complicated but be understood and followed. The teacher will need to help the children to use discrimination in making their plans so that too much ground will not be covered.

The exact procedure will vary with each group and with ouch trip. Some of the following are necessary for preparation on the part of the children:

1. The chlldren guided by the teacher should have a definite aisn or purpose for taking the trip.

2. A comittee of children might make the preziminary trip with the teacher to see whether they think the trip will help clarify and solve the class problem.

3. Supplenentary books on the subject might be collected by the children. The chilaren can ake a bibliogra-

\section{7}

Ernest Horn, Hethodg of Instruction in the Social Studien, New York: Charles Seribner's Sons, 1937, p. 412. 
phy of all reasing material pertaining to the axcuration. 4. Any inforwation galned by individuel menbers may be shared with the class through reports or illugtrstions.

5. The class wembers wight do as wen prellminary reading as possible in preparation for the excursion.

6. Clippings, photographs and pletures be placed on bulletin boards. And lizas, slides, or ary other appropriate audio-viaual aids wa be used both for inftial wotivation and for general oriectation to what will be seen an the trip 1 toelf.

Hille careful advence preparation of this nature is escritial, it should not be waie in too great detail; roce should be left for surprises and for the thrill of personal exploration and discovery. 8

7. Through the class discussion glided by the teacher the following way be accorylished:

(a) The class way outine points in surwiorizing their present knowledge of the subject.

(b) In settins ut defintte goale for the journey, the class was list specific questions to be asked and answered and defint te things to be observed. The teacher may add questions or problems coverins essential points not suszested by the sudents. Responsibility for askins these ques-

0leen, spe site, p. 166. 
tions, which are usualiy grouped around sonie toplc or problem, is delegated to amall groups or individuals. The children may choose the questions of interest to them. Any questions left over may need to be distributed by the teacher.

(c) The class wiay plan the ways and mearis of any notetaking, photographing or sketching, collecting pamphLets, posters, manufactured products given away, and any other activity that will add to the value of the trip.

(d) The procedures and conduct to be used while crosang streets, riding in vehicles, or at the place visited mast be discussed by the group. In stardards set up by the group, rather than rules imposed by the teacher, the children see their necessity and are not likely to break then. The chiloren must plan what to do if they can't see or hear, discuss when to ask questions and the care in examining objects and moving about and amcng them.

(e) Standarde of courtesy set up by the group would include good manners such as quiet volces, toking turns, helping one another, and keeping together in an orderly manner.

(f) If the group has been divided into conmittees, the group on transportation might find the best means. Studonts volunteer to ask their parents to take their cars for the transportation of the group. Any method de- 
cided upon should be discussed so there is no confusion at the last moment.

(8) The necessity and importance of cleenliness in the appearance of the group as well as the suitable and proper clothing for the trip should be freely discussed.

(h) The group my declde what equipment is necessary, such notebooks, drawing paper for sketehing, camera, or any other for achleving the educational purpose of the trip.

(i) If food is to be bought or lunch is to be taken on the trip, some discusstion should be devoted to the subject of a well-balanced menu.

8. A comittee of students might obtain the principal's permission to make the excurston.

9. After the time has been decided upon for visiting, the class in a group letter, or a comittee of studenta, witht write for permission to visit.

10. The class may assist the teacher in planning a schedule for the visitation. Then the necessity of keeping it will seem more important to the sroup.

11. If some industrial process is to be observed, carrying out certain parts of the process in a simple way in the classroom will acquaint the children with what they are to see on a larger scale. As an example, the value of a trip to a woolen will is enorwously enhanced for students who, as a part of their classroom work, have actualiy 
carried out in a simple way, the process of washing, cording, spinning, and weaving.

12. A class comittee might invite a few helpful parents.

13. The class should be orzanized for travel. "public relations, as well as physical safety, require that the teacher have some defintte procedure for insuring discipline during the trip, and also for making routine check upon the pupll attendance t various points along the Hay." 10

How can this be done? The children may be formed into groups with leaders. The teacher may determine the number of groups to be used and the approxlaate number of students for each group. The students should elect their leaders and then choose the groups to which they wish to belong. The teacher can, for the good of the class, make any necessary changes. These groups again would review their responsibilities, the need of alscipline, and what safety measures to be observed. The responsibility and detailed plannling affer greatly in terms of the level of maturity involved. This groupinä provides for leader-

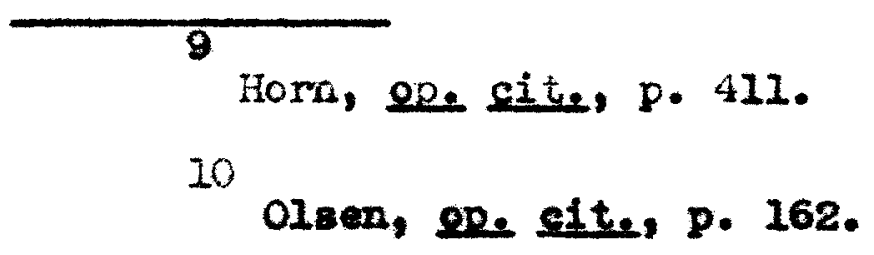


ship, followership, and good clt1zenship on 211 those who take part.

As the plan presented by Ade ${ }^{21}$ seems the beat that was found by the writer in the various readings, it will be presented here.

The children form into groups of from five to seven members. Each diviaion chooses a captain who is responsible for checking and reporting for his group. The captain way keep ready for instant checking a card on which is typed the names of those composing his group. The teacher also has a complete list of all captains and their group. When leaving a place where it is necessary to know that all are together, the names of only the captains are called. When that captain answers, "Present," that means that all his diviaion is there. For quick attention of all, the simple device of raising the hand is used. This means that there is aomething important to be said. Each child seeing a hand raised does the same until everyone's attention has been attracted. Everyone then araws close for a woment to receive instructions, information, or for roll call.

\section{1}

Lester X. Ade, Expanding the clasarocen, Harrisburg: Department of Public Instruction, Comanwealth of Pennsylvania, 1938, pp. 23-24. 
12

Pushing auggests that a pupil questionner may be appointed in exch group and all questions to go through this question captain. This prevents the many confusing and disrupting questions from individuals.

However, each member car be held responsible for seeing that his question has been answered.

14. Mapping out the trlp affords opportunities for reading historical and geographloal material.

II Conducting the Dxcursion

Flnal Check

Before leaving the school building there are several important details which the teacher should check upon, to make the trip a success as planned. with upper grade children the chosen leadero can asoist the teacher in checking on ame of the following:

1. The physical condition of pupils tray be checked and any child with symptoms of iliness may be left behind in care of the principal.

2. The appearance and the areas of the class may be checked. For example, any loose clothing that might bocome entarifled in machinery if the class is visiting an industry should be noticed.

\section{2}

Frances Rushing, "Organizing School Excursions," The Instructor, 53:29, February, 1944. 
3. Determine if each student has brought his correct carfare, lunch if needed, and any needed equipment.

4. Check again for notes permitting individuals to participate.

5. Send chlldren, who are to remain behind, to other rooms prevlously arranged for. Check to see thet they understand their assignment and have their books, coats, if they are not to return to their room, and anything else needed so as not to be disrupting to the other class.

6. Check again the travel liat to see if correct as of the moment and send a copy to the princtpal.

7. Again sumerize and clarify the purpose of the excursion with the class.

8. Ascertain if those students with speclal aesignments understand their responsibilities.

9. Bmphasize again the Importance of safety first. If there are any special hazards indicate their nature so as to be svoided.

10. Reviev the standards of conduct and courtesy. point out that the class bill be guests and to act thus. 11. Diamsa the class to get drinks and go to the toilet.

Proceed Bn Route

As the clasa files out of the school building, the teacher may go to the head of the IIne, and if any 
parents are assisting they would follow the ond of the Iine to prevent any strageling or faling behind.

If making the trip on foot and no adults are aseistIng the teacher, the best plan is to put the nost reliable pupils at the head of the line and the next most rellable at the end. The leaders can escort the children across the street at a signal from the teacher or a trafflc pollcenan, and stop some distance up the block so that the ent1re line, without too much crowding, can stand on the walk. If there 18 no officer on duty, the teacher may stand in the street and halt traffic. At a signal from the teacher the group may proceed to the next corner and walt for the teacher.

In walking the teacher must encourage the stragglers to keep up with the group and hold back the more inpetuous by appealing to their loyalty to the group.

If going by bus and fares are to be paid, a good plan is to have the group enter the bus in pairs with one child paying both fares for one way and on the return, the other child doing the sane.

The activities engaged in during the trip to and from the destination are subject to the varying conditions of distarice, time required for the trip, size of the group.

13

"Let's Find the Facts for Ourselves," The

Ineteuctor, 49.72, Jamuary, 1840 . 
and the noans of tramuportation used. Somatines the Journey is made a perlod of study and obsorvetion, and

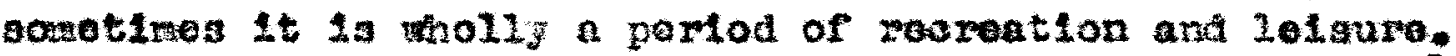
If the group 1 a on foot or on a private bus, oxsen suggests that warehing songe, sehool songs, or group ohoers be ancouraged to develop a destred "eaprit do corps" and to drain off a certain amotnt of youthrul exuberanes. Then the group is travellac together and not in separate ears, Interesting 1 tems ma be pointed out by the teacher tho has ade advance proparation. On the bus jokes rany rolleve the tedium of a lengthy ride.

sida interesta or tops not alrectly rated to the wojor purposes of the trip wust bo avolded so that the chlldren won't be confused nor interest dintinished wen arriving at tho duatination.

Tatch and stay on rehodulo. It is best to be fust a Ilttie ahod of tive to allow for unforeseen delay. Do not stay longer than the allotted tine in any one place. Approaching the elty deatinetion from the opposite side of the streat, onables the onlidren to ses thelr goul to the best adventage before they reach it and alwo helghtons thelr senee of expectaney. 25

\section{tens thedr sonso of axpoctanoy.}

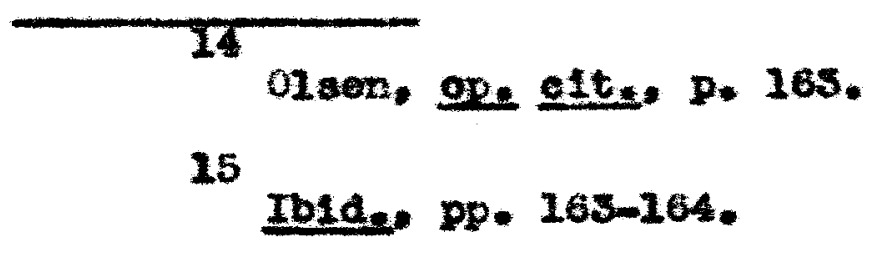


On arriving at the resoure conter the group nay wa1t outalde wile the texcher ontexs to mnoume the

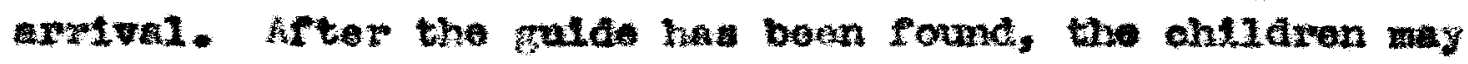

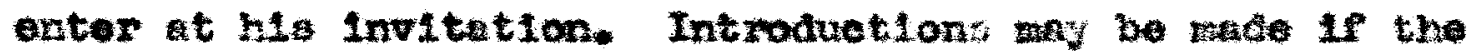

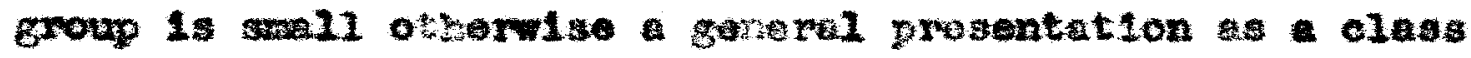
1. ourfletant.

\section{In the Conter}

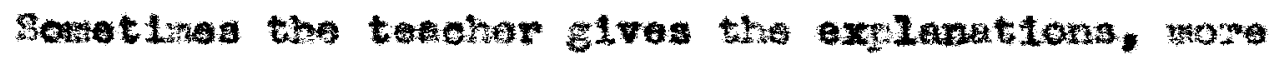

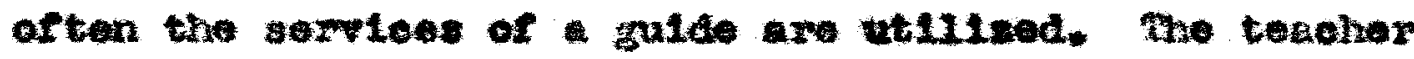
then thould have conferred previously with the salde as to the Inforwation desired on to prevent too wheh being told ovar the heads of the papils.

The toacher' vigllance wat not be relaxed evon if

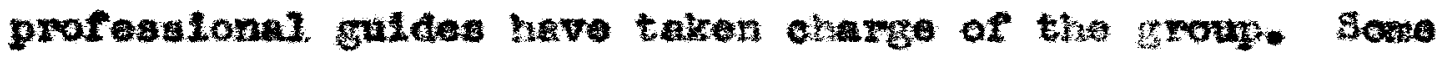
of the tencher's reaponsibilities the should not be overlooked Inelude some of the following:

1. The tonoher wast watch and keop the group together. Do not allow almloss randertng abont or undue attention to 1 molevant axhibito. Onllaron grow ratigued und lose lnterest if too wuch is aben on one trip.

2. The tonohar should try to soo that evory child has a chance to soe and hear what is occurngg for his benor It.

3. The teacher wust be alert and sensitive to the baokground fectors wah weather conditions, seating 
arrangements, ventilation, traffic movements, and any interests and influences of present or potential elgnif1cance.

4. The teacher wat watch for any disciplinary prob1en, but if the trip has been carefully planned this will probably not occur. Also if the excursion has the proper beckground of interest, discipline problems will amount to little.

5. The teacher way need to eselst or arrange opportunity for the students to carry out their previously chosen learning activities such as taking notes, oketching, photographing, asking questions, collecting specimens, making maps, and the Iike. The teacher ma need to ald some children in giving information when a point is not clearly brought out by their questions. If the pupils take notes during the trip it will help the questioners to keep clearIy in wind the answers to their questions.

6. The time must be watched carefully. If opeakers take more time than arranged for, the teacher will need to be tactfully insistent upon moving on at the appointed tiee.

7. When the group in ready to leave the center, the teacher will thank the guide or host and the children should be encouraged to exprese their apprectation an they go out. Everyone who served the group ehould be personally thanked if thi can be done whout disrepting the schedule. 
If more than one center is to be visited, review what has been observed, and sumarize it before going to the next deatination.

\section{The Return}

After the vislt has been completed, attend to the physical needs of the ohlldren before returning to the school.

If the return trip is after school hours, the children showld not bo left at their homes even though these are near, but they should be diamissed from the school building. Any perent desiring to take child home without retuming with the group should discuss this in edvance with the teacher.

Before finel alsmissal at the sohool the teacher should check earefully and quickly to see that everyone is present and that everything is all right.

\section{Appraisal and Follow Up Activities}

Completion of the excursion does not terminate it as a project. Much still noeds to be done before the trip's full educational value can be realized. "An important part of the learning activity is the evaluation of 
the trip in the light of the proposed objoctivos." 17 The cvaluation of the trip should strengthen the purposas of the puriza and rolnforce the toacher's instimotion. The mathods to be used in the ovaluntion wils be dotemined by the objectives of the excursion, but thoy should not be so rigla or burdensome that the nest or enthus1ssm for other oxouralons will be dulled. The activitios that grow out of the excuseston must be cleandy noeded.

Derinite follow-ug activitioa roxw in integral part of any well-wanagot oxcurotion. Such activities, if proper1. planned and sempted out, will enrleh the ourrieulua and Inprove the pupli-teacher sud pupl1-pup11 relationahlp because of the sharing of experiences. Pollow up notivities De* bo those whioh analyzo and appratso the trip itsolf and those which grow out of the informtion, appreclation. or Interests developed on or as resul of tho exeursion. The following ativities, durine the diseussion poriod soon after the trip. appraloo and analy at the trip:

A. fraluate the exouraton in term of ita original purpones or objectives.

B. Discuss the toples assigned of questions formalated by the atudents for thelr observetion.

C. Diagnose nistakes, Alfficulties, or any other

\section{7} Ade, ofe olte, p, 14.

18 01sen, ope elte. p. 165 . 
raults frow the atendgeint of leprovent in future oxcurstons.

D. DLacuse and evaluate the Individual and colloc-

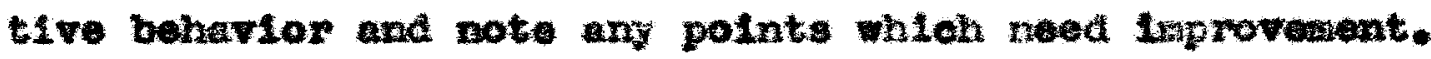
Satiafaction should be felt by the onlidren for achloving atandards set up.

3. Clarify fact not thoroughy understood, oorroet any wong lopresalons, and angwer questions that might have artsen in the otwdents" alnds.

F. Reeord the highights of the trip for ruture use in some permanent form.

Q. Evaluate the skotohes or an other oxutive expression wade at the seone of observetion.

1. Provide opportuntty for additional explandtion of matters of spoinl interest and leportance.

I. 留rite lettars of thank for assiatance and privileges during the trip.

Bverg succesanul excursion may arouge now interests which are of odzoational algnifloanoe if properly atima2ated. Opportunity wust be provided for mental, motor. and enotional activitios thet may be the outgrowth of the exourston expertance. Some of the following follow-up activities are examples of exprosion of exergent intereates

A. Express the ldoes and feellnge galned through oral reports, witten compoltions, booklets, serapbooks, 
photographic exhibito, lantern slides, graphs, maps, charts, diagrams, sketches, mura28, drawings, scaled models, dramatizations, puppet shows, a home-made novie, or radio programs.

Vany writers euggest that some place in the building should be used for chlidren's exhibits or any other followup work to be kept for aharing wth others. This would help to develop a growing interest in the community emong both teachore and pupils.

B. Discuss the signiflcance of things learned as they relate to the unit or problem.

C. Relate Important flndings to the other subject flelds in order that the children may see the essential unity of all knowledge.

D. Test for increased information or changed attitudes. Opinton is divided anong educetionel writers on the use of tests. Scme criticise it as destroying interest. It ma be inadequate for discovering certain t,ypes of outcomes such as appreciation. Scme of the other above activities provide the teacher with ample information about the value of the trip or elinch the points the teacher wishes the pupile to make.

E. Share the experience with others. The group may have arrenged, prior to the trip, a program based on the excursion to be presented to the mothers or for another 
class. This might include a play, short talks, exhibits, posters, plctures, or slldes. Sharing experience might be In the form of reports to the school newspaper. Such activities as these offer the children many opportunities to select and organize their information on the basis of 1 ts interest to othere. This would be a check in determining the standard of what the group considered most interesting on the trip.

F. Investigate new problems raised by the experience. This mlght lead to new units. "The value of an excursion is not 80 much the acquisition of speciflc information as the raising of new problems."

These activities resulting from the excursion break down the artificial lines of formal subject matter, and thus make the class work more interesting and meaningrul. These activities interpreted, ma aid the teacher in appraising the trip as to its teaching values and its constructive influences on pupils.

\section{Summary}

There is no absolute unformity in the administration of an excursion because of the varieties in their aims, their character, and in the condition under which they are

\section{9}

David Weaver, "Excursions in a Metropolitan Center," Pational tenentar Principal, 13:294, June, 1934. 
made. Flexibility of procedure is desirable in the preparation of the class, the plen followed at the center, and in the kind of use made of the excursion in subsequent cless work. But it must be emphasized again and again that careful, suitable preparation and retrospective emphasis on the highlights of the excuration are essentials of a successful technique to provide vital educational experiences. An Excursion to the Loulsville and Portiand Canal

The 5A Class of Stephen Foster School was composed of thirty-seven boys and girls, but during their soclal studies period elever other $5 \mathrm{~A}$ students joined the group in the study of "The Ohio Valley." The group, on the whole, was of average intelligence with a few exceptional bright children. As stated before, during their group planning for the study of the undt, the class had listed making trips or viaits to places in the city as one of their activities.

The writer has chosen one of their trips, to the Loulsville and Portland Canal, to tell how It was planned, conducted, and followed-up.

This trip was antgrowth of one of their social studias perlods when the class was discuseing the importance of the Ohio River in the settlement and development of this section of the United States. Let's listen in at this part 
of the discuseton.

"I think because the Ohlo River flowed westward that 1t helped settle this part of the country," sald Tom. "Wll you explain that, Tom?" asked Mary. "I don't understend just why, that would be important."

The people who settled in this section (The Obio Velley) had trouble in moving westward because of the Appalachlan Mountains. Whenever they could they would follow streams and crose at lower places. After they reached the west side of the mountains the pioneers would bufld flatbosts and travel down the Ohio. It Rowed westward so It beceme a favorite route for aettlers," he explained. nThese pioneers looklas for new howes would float down the river," spoke Harry, "until they came to pleces that looked good for farming land. Then they would atop and settle there."

"Often familles would travel together and build homes near each other. Sometimes they built and lived in forts for protection," added sue.

"After a settlenent bogan," eald Jerry, "others came to join their friends or famillea."

Martha standing with a puzzled look inquired, "But why did some settlements grow faster than othere?"

"I think their location would be the main reason," anawered Harry. "Scme settlements were in better farming 
sections than othere or there would be waterfalls to turn their mill wheels."

"Harry, aome settlements grew because of a broak in transportation," added Ton.

"What do you mean by that, Tom?" asked Martha.

"People treveled on the water until they reeched falls or rapids," he explalned, "then they were forced to stop. That place would be the break in traneportation." "Louigville is an example of a city that grew that way," added Mary.

"Yes, I remember that Mies KInkead at the Fileon Club told us that long ago the people traveling on boats had to etop above or below the falls and go around by Iand," related Don.

Jerry hastily added, While they had to unload their boats they needed shelter for therselves. So inns, livery stables, and tores grew up near the falls to serve the settlers while they were making ready to continue their trip. More people came here to live and trade began to grow between little towns on the river."

"I suppose," explained Dolly, "that is why Loulaville was later called the 'Gateway City,' because people and cargo from the North and those frow the South passed through here."

"Stagecoeches and wagons were used to carry the 
people and cargo from Fourth Street to Thirty-fifth Street," said Don.

Mike, a new boy who had just moved into the city, inquired, "Do they st11l go around the falls?"

"Oh, no, Mike," answered Harry, "a canal has been

built around the falls."

"How dces a canal help a boat get from higher to

lower water or the other way" Mike asked very puzzled.

"The water 18 raised or lowered in the locks for the boats," Harry replied. "I can't explain how it is done, however."

"I'd Iike to know more about the way that can be done," Mike stated.

"So would I," answered several others.

Maybe we could flnd scme information in our geography or in our encyclopedies about canals," suggeated Martha. John also suggeated, "Or we could take a trip to the canal as we did to the FIIson Club."

"That would be nice," agreed many others.

"I think wo should do both, read and take the trip," replied Helen.

Mrs. Moore, may classes visit the canal?" John inquired.

MYes, several classes have vialted the locks. I will contact Mr. E to aee if we might come. After you make ar- 
rangesents and decide when you want to go, tho class may send a letter epecifying the date and the ture," ohe answored.

Mery suggested, "ve could write the letter together In our language lescon and copy it during penmanship."

"I hope wine 18 chosen as the best to send this time," byoke sue hoperully.

"Bofore we do any reeding I think we should 11 st things we want to find out," auggented Helen. "If we can't find answers to our gueetions as we read we may ask ur. E. when we visit the canel."

The following question were tated by the class and placed on the boand for everyone to see and for reference: 1. When was the Loulsvilie and Portland Camal bullt and by whow?

2. Who owns the canal?

3. Where doeg the canal begin and end?

4. How much zust the boate pay to use the caral?

5. How do the boets use the canal to go down-tream? For upetream?

6. Does the rising of the rivor affect the canall

7. Hat signal do the boats give when they want to use the cansi?

8. Low long cices it take a boat to go through the cenal? 
9. About how many boats pass through the canal in a month?

10. What are some of the things the boats carry?

12. From where do most of the boats come?

12. How many people work at the canal? Do they belong to a union as do the telephone workers? (The Hation wide telephone strike was on at this time.)

13. Are boats ever damaged in the canal?

14. Are the locks the canal gates? How large are they? of what are they made?

15. Do all canals serve the same purpose a does the Loulavilie Canal?

16. About how much water is needed to fill the locks?

The remainder of the lesson was used as a study period. Sone children crowded about the encyclopedias and the library table, while others were busily thumbing through the index or table of contents in thelr own textbook. Soon all were busily reading or jotting down notes as they went along.

The social studies class the following day was begun wh th one question in rind, May we go to the canalin"

Reassured that the trip might be made, the class began pooling their information found in the hours since the last discussion period. 
20

"I found some information about canals in our geography book on page one hundred elghty-one. May I read it to the class?" Bob asked.

"Yes, Bob," replled Mrs. Hoore, "we want to hear your information."

Bob stood and read slowly and carefully. "Perhaps you wonder, however, just how the canals help ohipe get from lower to higher water or from higher to lower water. This 1. all done by a number of sections of the canal known as 10cks. At each and of the lock is a gate that holds back the water. When bout is going upatream and mat be lifted, It slowly steams into the look. The gate back of the ship is closed and the one in front of it is opened. Water from the higher part of the canal then flows into the lock and raises the bost. When a bout is going downstream and must be lowered, it slowly steame into the lock just as before, except that it is going in the opposite direction. This time, when the gete back of the boet Is closed and the one in front is opened, the vater rune out into the lower part of the canal and lets the boat down." "Do you think that you could 11lustrate thin on the board for ua?" Inquired Tom.

$\mathbf{8 0}$

W. R. Meconnell, Living in the Amertases Hew York: Rand Mctially and Company, 1939, p. 181. 
Bob hesitated moment and then as he drew lines and arrows he explained the way the boats use the locks. mhank you, Bob, your explanstion and information was very clear," complimented the teacher.

Helen stood to add her information, "I found that our canal in Louisville was built in 1830 by a private company and the firgt boat to use the canal was on December 22, 1830."

"That is different from what I found out," replled Sally. "I found that the canal was completed in 1829." "Ye'Il ask Mr. E when wo go to the canal to see which $1 \mathrm{~s}$ correct," replied Helen. "I also found that the canal is owned by the United States Government. It was bought from all the owners by the government because It controlled the traffic going up and down the onio River."

Bob inquired, "Did you find the cost for a boat to use the canal?"

"Yes, I d1d, Bob. It once cost $\$ .80$ per ton. After the government bought the canal they charged too unt1I 1880. After that nothing was charged," she answered.

"Bob has told us that the locks are sectlons of the cans.1. Did any one find out how large the locks are?" asked Jerry.

"I did, Jerry," replied sally. "The locks now are one hundred ten feet wide. The longer cae is alx hundred 
fifty peet long and the amalzer one is three hundred feet in length. They wera enaller when they were first built but they have bean wade Iarger."

"Skx bundred fifty feet is long. 'I wonder if that is longer than our school corridor," eald Jack puzzled. "an surested, "we could measure the leneth of the hall and cowpse our measurenents with those of the locks. Lay we leasure the hall during our arithetic lesson?" "Yes, that would be a very $800 d$ arithuetic lesson, Tow, "answered urs. Noore.

Wy father tola me that they use to dredge the canal to take out the mud that had collected," explained Sam. "I'd like to find out if they still drede the canal and how."

Joln asked, "When car. we 80 to the cavili" "Mhursdar would be a sood day," sussested uary. "That would give us tise to complete our plans." "How car we go?" isguired Sally. "When we went to the Filson Club we had so sach trouble in getting enough cars for our large group, appose we 80 by bus," auggested Hary.

mpat would take too long and we would probubly have to transfer and walk," Jerry replied.

oy father works for the Louigvilit Kailway Cosapany," said Laurs. "I can find out if we could cherter bus and 
the cost."

"I slizgest that Laura, Jerry, and Sally be our transportation comittee. Then tomorrow all the people who can get cars report to them. In the meantime they can find out about the bus, so we can declde how we are to go," suggested ËEnry•

"That wolld be fun to go on a chartered bus and pass the people at comers without stopping, "said Tom teasingly when the social studies period was finished.

The next day Laura reported, "The cost of the bus will be ton dollars. Sally and Jerry found that only two cars were avallable but that won't begin to take our large class." "With two dollars in our class fund we can add the difference of eight dollars," replied John.

"I'd rather pay more so we won't have to transfer. We can go directly there and all be together on a bus," added Jerry.

Some of the others agreed.

"How much will we have to pay?" asked sue.

"That's a good arithmetic problem. Let me see who can be the first to give us the correct answer," challenged Mrs. Moore.

Pencils were busy, but Harold was the first to ralse his hand.

"Harold, you may go to the board and show how you 
sclvad the problen," said Lrs. "zoore.

Harold wrote:

10.00 Cost of hus

-9.00 In our fund

48.00 still noed

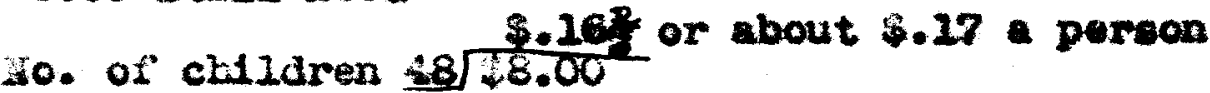

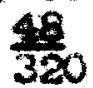

$\frac{289}{32}$

"That is only two conts wore than zegular carfare," added SaIly.

The teacher knew that four chlidren in the roor wight be unable to pay their sares. As the school bas a fund, the techer knew that their cooperative principal would see that these fares would be patd if necessery. Therefore, the teacher at a later the discussed individually with these four pupils and a plan wes worked out.

"Then I shall have tay tather to cherter the bus for wa," replied Laura.

"Bince soule of wur nothers were so nice to take us on other trips in thelr cars, I think we ahould frvite then to be our duasts on this trip," suggasted sue.

What a aice suggestion, Sue. I would l1ke very wuch for sone wothers to share the trip wh us, "replied isro. Hoore.

Wie cust write to $\mathrm{Mr}$. If, added Lartha, "to tell him of our plane." 
"Do we need notes giving us perralssion to go on this trip, Mrs. Moore?" Inquired Bob.

"Yes, Bob, it is very importent that everyone bring his note algned by a parent. If anyone fails to do 80 , he won't be permitted to go."

"Since many of our queations are otill unanswered, may we choose one to ask in order that we will get all the information we want on our visit?" Mary inquired.

"You may choose question," answered Mrs. Hoore. Mary will put your initials on the board by your question, so you can copy it later."

After the class members chose their questions, it wee decided that notebooks should be taken to record any information that Nr. E would give the group, also for oketching anything of interest.

"I'a like to take my camera to take pictures of the canal," Sue added.

"That would be a nlce pleture to put in our clase booklet," replied Helen.

May we divide into groups with leaders as we have done before?" inqulred John.

"Yes, John, we need about six good leaders for the group," euggested Mrs. Moore. "You may elect them and choose the group to which you wish to belong." After the class voted, a few changes were made as 
some groups were too large. Some of the puplls volunteered to change to a analler group to make the groups even. Three chlldren were changed to separate groups becalise they had proven before that they could not work together.

"Shall we use the same etandards of courtesy and conduct that we mace before?" inquired Bob.

"I think we should ade one," suggested Sue. "Stand back and not crowd around any object being pointed out. Everyone can see then, and you can always look later when It isn't so crowded."

"Our trip to the Filson Club was an example of the need of your good standard, Slie," pointed out the teacher. "Suppose we review our standerds and see if they are necessary for our trip."

This was the subject of the discussion for the remainder of the period.

For the next social studie leason the movie, "Flatboatmen of the Frontier," was shown to and discussed by the clase.

\section{The Excursion}

The day of the trip arrived. Some eager child had already epled the bus, as it drove up ten minuter ahead of time, and had at once reported the fact to the class.

The list of the children's names who were taking the trip had been sent to the office after the notes were check- 
ed carefully by the group leadere with the teacher.

Eech leader had been given card with the names of their group. This had been typed by one of the small girla on her toy typewriter.

After each leader checked his group to see if everyone prepared for the trip, he reported as his name was called.

The mothers had met in the rocul during these last minutes of checking. They had previously talked with the teacher and were told how they aight help to make the trip successful.

The group following the teacher, flled quitly down the hall to the bus waiting on the outside as the mothers walked at the end.

On the short ride the class had been giver the opportunity of telking in low tonee. A raised hand meent that all were to stop and listen to anything that might be pointed out. This was done as the class passed the IydroBlectric Plant near the locks.

On arriving at the powerhouse the class remained on the bus with the parents unt1l the teacher located their guide.

Mr. E, this 1a the 5A Class of Foster School." "Hello, boys and girls," he replied. "I want to take you flrst to the powerhouse where I will explain some of the 
controlling instruments."

In the powerhouse several terms were jotted down, not exactiy in their rigit apelifin axrangenent, but that woula be clartised later. Ho one crowded about as verious things were pointed out. Later few ginutes were given for closer obaervation.

hs the children 200ked down at the 20cks from the upstairs window of the powerhouse, kr. E explained bow the Locks worked.

"Before we go downotalrs and mik to the bridge, are there an questions?" he asked.

kenrieth, wo bea listened intenty to eee if the answer to his guestion would be given, wae the flrst to speak up. "Of what are the gatee in the locks meder" "Steel, es they need to be very strang."

"How lung does it take a boet to go through the 20cks?"

"hbout fifteen to twenty ainutes."

"Is the carnel still drudged? If so, how" asked Sen.

"Yee, it is necessary to dredige the rock bottom canal about once a year. If the strear falis to a nine foot stage and there is very men wud, bis bots would be unable to use the canal. Feter in the canal is known ae dead water and if mad is to be removed, the current of the 
river being lacking, the dredges met be relled on. Previous aredring bave beea 'dip dredging' or 'clan-bucket' affalrs. This yeur they are to use a suction dredge." "How is that doner" akked sem anxiously. Men on a bont cut the mud from the botton, then 1t Is sucked up by wachinery at the bow and pumped through a pipe to the widdle of the river where it is easily carried away by the current."

"Thank you, that 1s very interesting," roplied sem.

"What we the name of the flret boat to use the canai3" acked Hary.

"I don't know."

"I know," anowered Jack, "I found out that it was celled the "Uncas."

"I didn't know that, son," replied ur. E.

"yhat are some of the things that are carried by the boute that go through the canalz"

"Cotton, sugar, scrap iron, erude oll, and many other thinge."

"Where do the bouts come from?"

miny pleces, but several come and go from PItteburgh to Hor Orleans."

"Are boute wer damaged in the locke?"

res, and scmetimes the wile of the locke are damaged aleo," he answered. 
II found that it takes about fourteen million gellons of water to fill the 2ock. Is that correcti" asked Helen

"I don't know exactly, but that is about correct. Sey, I am going to keep you poople down here and ack you queatione. You know more answers than I do," he jokingly replled.

Bveryou laugh or amiled.

"About how mary people work here at the canal, and do they belong to a union as do the telephane workers?" John 1nquired.

"There are about thirty-nine people who work here, but we cowe under Civil service."

rohn Jotted down Civil service and a question mark rather puzzled.

"iny other questicns?" (A palise) "If thet is all the questiuns we' 11 go dow and look at the 20cks from the uridse. After we 80 to the other side I' 12 bave the wen to swrits the bridge around so you can see how it works when a bis boet ccoses through."

This wa done wucin to the delight of the children before they were taken to the drydock.

While at the drydock Tom looking at the weter suddenIy exclained, "Oh, I0ok, here comes a bout jom the riverl" This remerk, like an electric current, exclted the whole group. 
"Vie'11 go back to the bricge end watch tre boat go through the canal," suggestad ${ }^{\prime} r$. B.

Very fow alnutes were lost on the return trip to the briage.

Slowly the bot floated on the water to the locks. Then the gate opened for the boat to entar.

In a row nimites down You can't see all of 1 t now."

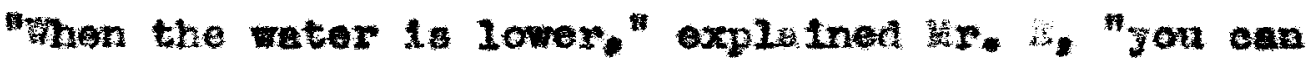
barely see the bat."

The gete has opened and the boat is going on down the river," sala Jane.

"0oe. I so glad the boat oxwe so we wero able to 200 It go through the locks," replied Farola.

"Boys sni ginls; our tine is about up so we'11 nem tum to the bus now. Thank you, lis. ${ }^{2}$, for the interost-

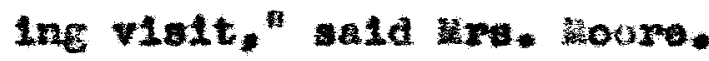

"You wero wheh nice boys anc ginlo and wo've enjoged having you visit us. Cowe back agein and '11 armange to take bost to go "10eking through," Invited sr,

"Onl that would be ful" wang volees oxolalmed in unison.

Several chilaron as they flled by to go to the bus ald, "Thank you, wr. E for the nice vialt. We have loamod so wach." 
Before the bus pulled away, the group was aeated comfortably and the group leaders, who had checked to see if everyone was there, reported as thelr nemes were called. The driver, instrueted to do so, pulled the bus away and the ohlldren waved goodbye to $M r$. E.

on the return trip to the school ell eyes were on the river to soe if any boats were on their way to the cansi.

As the bus pulled up to the school bullalng the. group was chattering as there was so much to talk about. The Follow-up

During the discussion soon after the trip, each question that had been formulated by the group, was again answered and discussed by the class members.

Only Harold seemed puzzled when he gave hls anower, "Thore are thirty-nine men that work at the canal. They are under Civil Service. I om not sure what kr. E meant by that."

"I do," explained Sally. "When we read in history about Andrew Jackson and other Presidents giving jobs just to their Prlends. Mrs. Moore told us that most goverment jobs today come under Civil Service. A person recelves the position who has the most points after taking tests with others."

"Oh, I remember that now," replled Harold. 
We should write soon to Mr. E to thank him for our nice trip," sugsested Jane. May each of us write a letter this twe instead of a class group letter?"

"That would be very nice, also a good check on what we have learned about letter writing," answered Mrs. Moore.

"I hope Sue has a nice picture of the canal so we might put one in our class notebook." "Who," continued Polly, "will write the report about our trip for our notebook?"

"Suppose each person rite at least a paragraph, or more, and tell something about the trip, for example, what you learned, or whet you enjoyed. These may be reed leter to the class, who may choose several good ones for the class notebook," suggested Mrs. Moore.

"We had such a nice trip. I think we should share our experience with others," Martha suggested,

we could write a report for our school newepaper, "The Luric". We can draw pictures about our trip and choose the best ones to put on the art bulletin bourd in the cor ridor for all classes to see. We can include a report of our trip in our class assembly at the end of our study of the unit." These were scme of the suggestions that were to be carried out by the group in their other class periods. During some of their art perlods pictures describing the trip were made. Descriptions for the pletures were 
written during the language periods as weil as reports for the class notebook and school paper. In apelling, mords were added to the class 11 st as necessary for whing their reports. These included the following: cargo, canal, locks, transportation, downstream, upatrean, and dredge. Permanshlp became more than just another subject. There a need for witing as neatly and legibly as possible. In music such river songs as Moonlight on the Waba" and "Beautiful Onio" were learned.

In the social studies period the clase also discussed the importance of the river today. Besides the use of the river as a means for boats to travel and for food, It was pointed out that the Ohio rumighed Louloville with ite electric power. The class had remerbered seeing the HydroElectrie Plant on the way to the canal. The river as a water supply for the elty with the necessity of ite purification was the basis of the many health lessons that folLowed.

Besides as a means of motivating and correlating their school work and providing first-hand information, this clase excursion had provided opportunity for cooperation in carrying out the plans for the vielt. 
CHAPTER VI

SUUARE AHD CONCLUSIONS 


\section{SUMMARX AID CONCLUSIONS}

No educator w11l deny that an important phase of each teacher's work is the provision of a rich and stimulating onvironment in which children will have contect with ideas, and with major human achievoments.

"Trips and excursions are necossary supploments to the classroom in providing such environment, for they invite investigation, exploretion, experimentation, and geining of knowledge and appreclation by first-hand contact with iffe, people, occupations, and creative works of man, local enviroment, and the porld at large."

According to the old maxim. "Seelng is belleving." Through exeursions chlldren learn to do more than just 10ok, they atudying the onviromment, reeording information, and organizing and interproting materials.

The values to be derived from excursions will be attalned or realizad when the excursions are planned as to what is to be accomplished and the manner in which the trip is to be made. Also for the ovident success of the trip evaluation and follow up activitles as well as proparation are nocossary if its posalbilitios are to be realiz-

1 F. C. Borgeson, "Excursions in School Life," Blementary School Princ1pal, 11:461, Apr11, 1932. 
ed. Of course, the tescher also must be contial to thif phase of school 11fe.

This study has only turned the ton soll of the rield which has burted in it a wealth of material for ezcursions sor all grades. Ag this study was 1 imtted to one srado and for one soctal studies unit, only a beglining has been made to ungerth these poselv111tios.

The writer hopes thet other surveys of the cormunity will bo made for all Erades and in connection with the entire currlculum. As suggested in Chapter III this survey night be made $b_{v}$ the teacherg of the entire sohool system wh comptteo to omzanize the eindings in some form hish would ho conventant for reference when armanemets wore being wede to visit. This infomation inght bo kopt at the Bard of Education in the Llbrery or In the AudLo-V1sual Edvoation Department. Bach sohool might have mimeographed coples to stud and to add any information portalning to the relationshtp of the sohool and the sovrces avallable. Exportences of classes and eroups could be added to this flaxtble filo of portinont Informetion about a comaunit in a constant state of flux.

The writer does not sugest that a separate special department be establs shed for caring for school excursions, as hes been cone in sone clties. However a type of field 
aervice as $1 \mathrm{~s}$ provided in Minneapolis for pup1ls and teachers could be had in the Loulsville system. This Ineludes a fleld worker devoting full time to providing helps for teachers, arranging for transportation, and raking contacts with the institutions to be visited. This service then is supplied at the request of the individual teacher. This fleld worker coula be a part of the Audio-Visual Education Department under the Curriculum Division at the Board of Bducation. Through this worker exeurstons could be cleared so that no one source is over used. As an example, if in the study of communtcation a class wishes to visit a radio station, the field worker would see thet too many classes did not visit just WAVE but to use other stations.

Teachers cannot make participation in an excuration obligatory as long as chlldren's expenses are borne by parents.

Provision in the school budget for expenses of transportation, the chief item of excursion costs, is necessary for the full use of the technlque. In school budgets today oosts of laboratory equipment and instruotional material such as books, motion pietures, and others are accepted as a necessary and legitimate expense. If the value of the excursion can be proved to be oqual to these, it wowld seem logioal for its cost also to bo in- 
oluded in the sohool budiget.

Sxperizental studies in this oystem might be made to prove the value of exeurbions and as basis for their provision in the budget.

Thi proposed part of the budget for trangyortation expenoe alght provide the use of sohool buses ox just flianolal aid to classeo for utilizlne regular olty trangportation frodiltioe.

The writer is not offering a golution or one plan. as that is not the purposo of this study. Just enggesting possibilitiea if tise teahnique is to be used extensively.

It is hoped that the flndings of this study wixl help others as vell as the fifth grade teaohera in thoix ceaching of the occial studies unit, "The onio Valley."

While it is realisod that this atudy ig far from complete and questions reratn unanarerod, the writer foela that a raml contribution ha been aude in this conneation. 
BIdr. ToGhat 


\section{BIBLIOCHAS}

3002

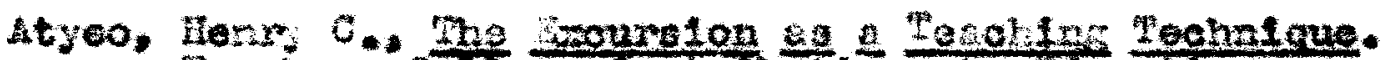

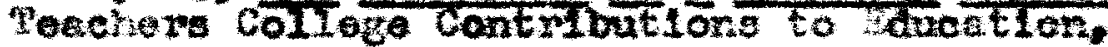
Wo. 76I. Wew Yoxt parean of fublicetiono. Teackers College, Columole InIverstey, 1939.

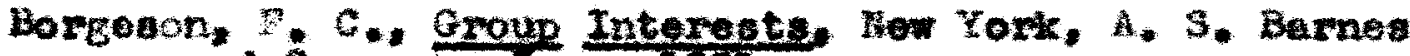

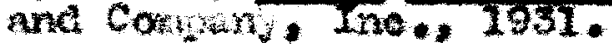

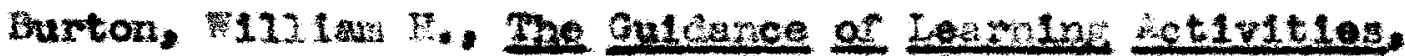

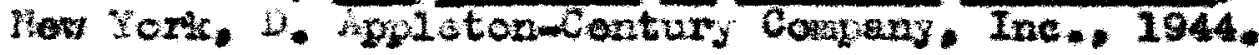

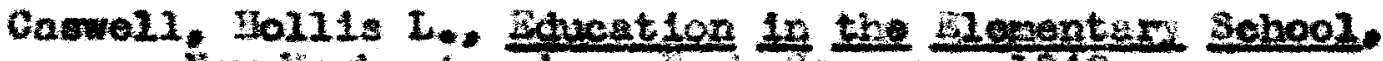

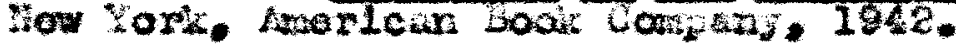

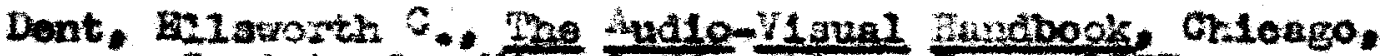

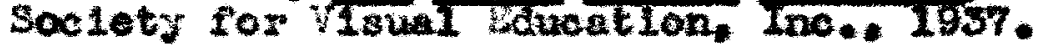

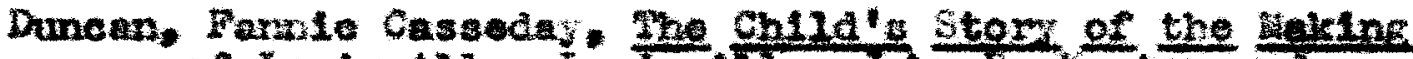

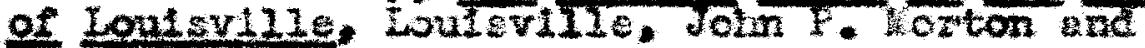
Dotpany . TSIE.

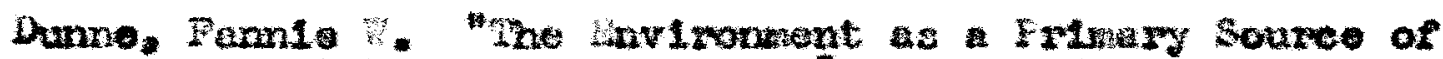

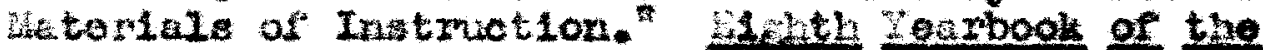

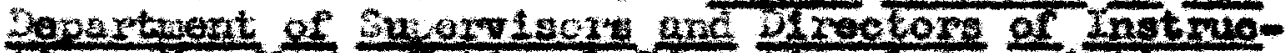

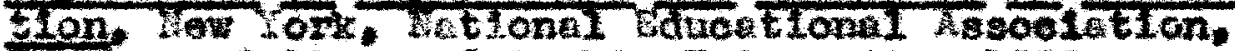
seachore college, Columbla Dnsverelti, 1985.

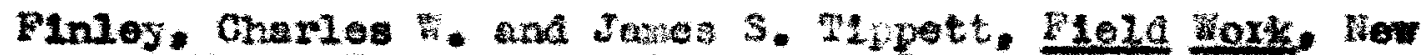

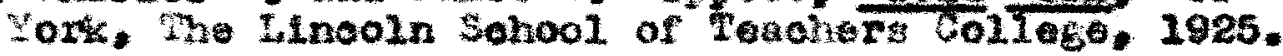

Freser. Trias. Qutcowea of a Study ixcuraton. Totehore

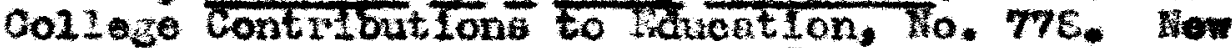

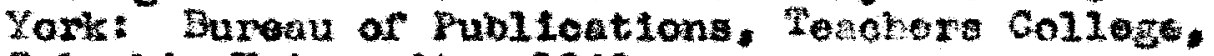
Coluebla Untvorsity. 1040.

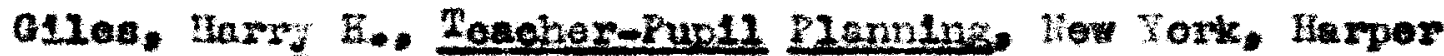
and Drothers. 104 .

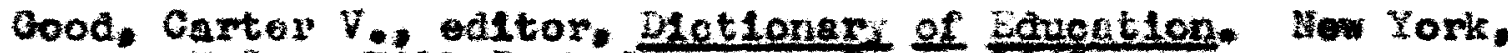

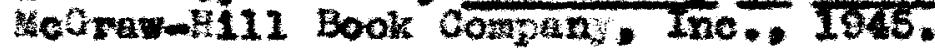

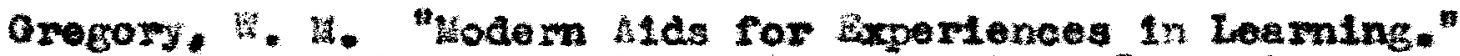

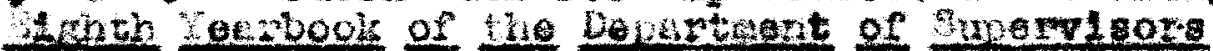

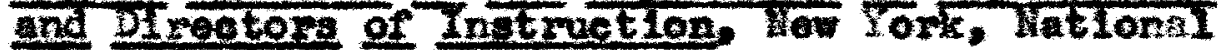


Lucetional Association, Teachere College, Columbla Dniveralty. 1985.

Group DIsnning in Eduet 10n, 2945 Yerrbook, Departwent of supervision and Currtoulum Developant, Nat ional Eduestion Association, wasisngton, D. C., 1945.

Hass, Kenneth B., and larry q. Parker, Ereparation and Uae of Vimuil Atan, New Yoris, Prenticemair, Ine.. 1946.

Foben, Charles $F_{*}$ Charles F. Hoban, Jr., and Samel B,

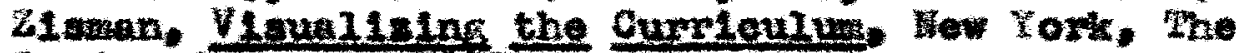
Corton compeny. 1857 .

Hocitett, John and $L_{\text {, }}$. Jacobsen, Jodern Practloen In the Elemontar Sehool. Boaton; GIm and Compens. I938.

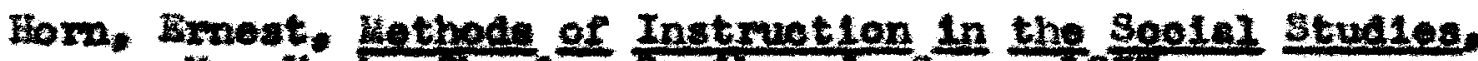
Now Yoxt. Charios Soribner's sone, I9ST.

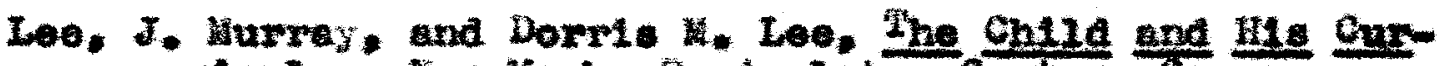

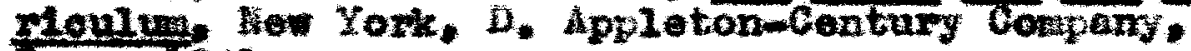
Ine.. 1941.

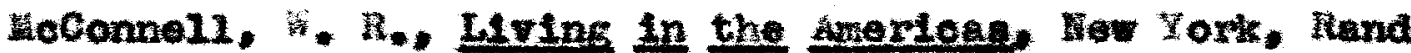
Helially and Company. 1959 .

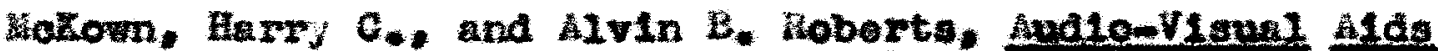
to Instruction. Hew York, UeGrai-Hin book Company, Ine.t 1940.

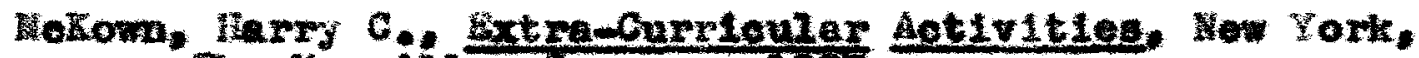
The veanilien company. 1037.

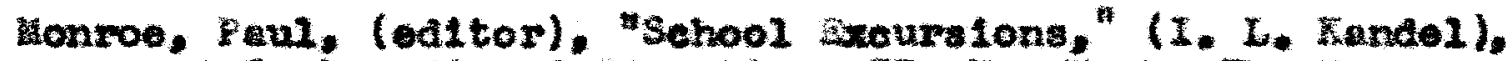
A Orelopedir of Gaveation. II, Now rork, The syo-

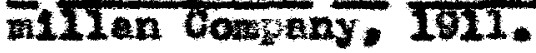

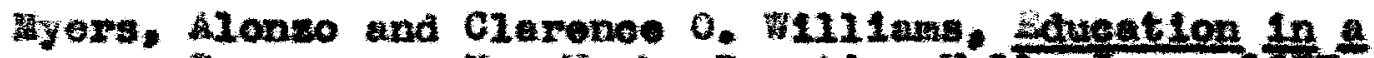
Demograox, Hew York. Front1ce-riall, Ino., 1987.

020en, Sdward 0.. Sohool and Coraunity. Wew Xork, Front10eHall. Inc.. 1945.

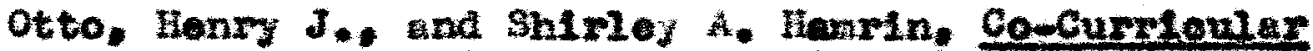
Activitiog in Sleraentax Sohoois Now Xork. B. Appieton-entury Company. Ine.. 1937. 
HIVIIn, Harry H. (oditor), "Sehool THpo" thoyolopedis of

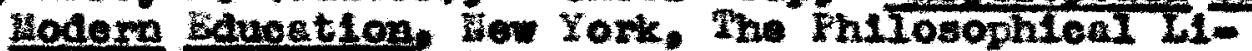
brary or hew York City. 1943.

Schneldeman, Rose, Demooratie Edueat $10 \mathrm{n}$ In Eractiee, Hew York, Hiarper and Brotherd, 1945.

\section{Ferlodioal Artioles}

AnIbom. Irene L., "Peter Vialta the leter Plant," Bdueational Leederehin. 3i58-62, November. 1945.

Bloveh, Adelalde, "Pleld Aotivitles in the Midalo Grades," The Journal of Georrephy. 39:246-48. September.

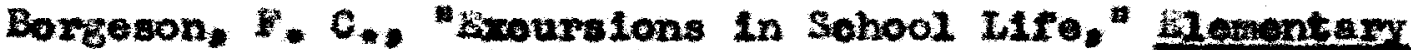
Soboal Prinelpel, Gloventh Yearbook, 46I-6, Apm. I962,

Bowen, wapd C., "me Behool Journes:" Edueatlonal Sereen. 19:125-6. 203, May, 1940 .

Brembaugh, Plorence The Instruetor, 4428,63. September, 1936.

Hruner, Herbert B., "Some Requi roments of the islementary

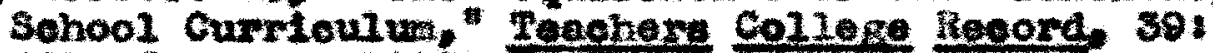
263, Jamury, 1939.

Bryan. H. Blolse, "Out of the Classroca into Life," mentary Sehool Principals. Thirteenth Yearbook. 278-85, June, 1954.

Castle, Elizaboth, "A Mrip to the Roundhouse," Sohool Art.

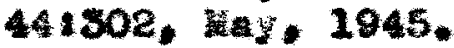

Clark, Blla C.. "An Sxperimental Svaluation of the Sehool Bxcursion, Journal of kneribentel Equation. 12:10-19, Sopteaber. Ioss.

claxt, L. Kathering. "Making Comanity Study sreotive in the Grades," Soelel Gaveation, 1111-14, February. 1940.

Curtia, bulght $K_{*}$ "Contributione of the Excursion to Understending Journal of Educational Regearah. 381201-212, Loventoer, 1944. 
DLeil. Ivan 6., "Hethod of Iroceduze For an Rourston," The Journal of Geogrephi. 30:78-80, Fobruary. 1940.

Reuerstein, Lme, "How To Get the host Out of sducational

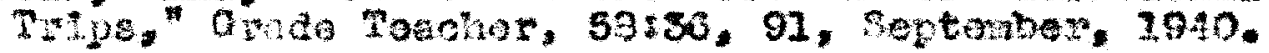

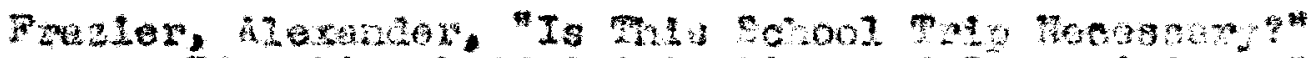
Eduestiond Adrinistration and Burerrision. 32t Mi-7b, WaFoh, 1946.

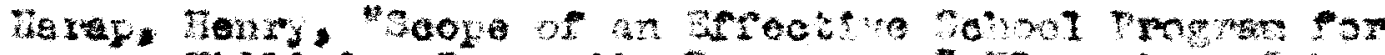

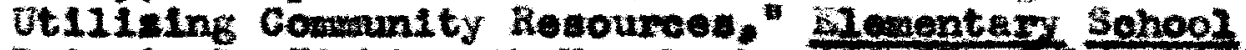

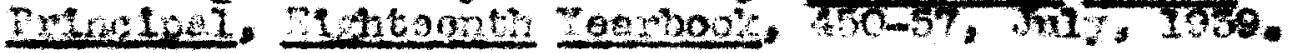

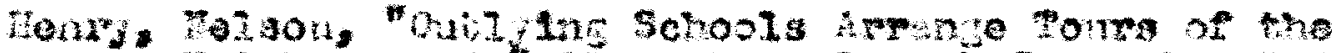
Neighborhood," slomentar Sehool Jouman, 421408 -

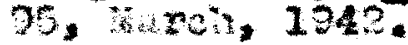

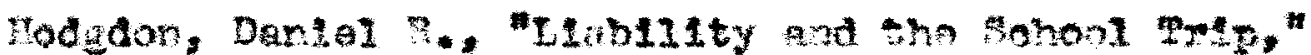
Glearlng Houge, $17: 433-34$, wroh-April, 1943.

llorsuan, Ralph D.. "Ysiting and Studying Looul Comauntty

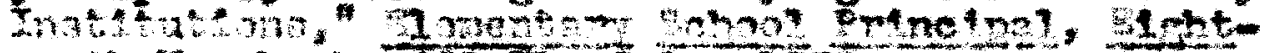
eenth Yearbook, 465-7, Juiy, 1950 .

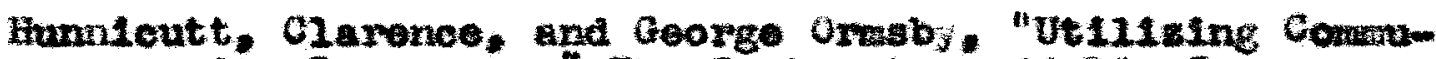
nity Resourees," the Instmetor; $46: 10$, January. 1940.

Jones, Anna B.." "Sowe Experlences in Vaing Commity fle-

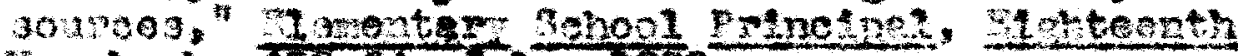
Yaurbook. 758-64, Ju1Y. 1989.

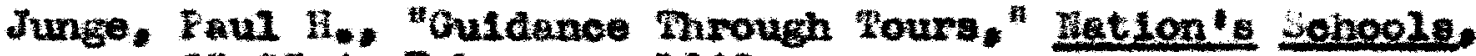

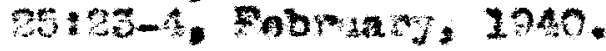

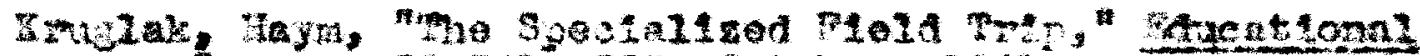
Soreen. 201341, 365. Ootober. 1941.

"Let" Find the Pects for Ourselves," The Instructor. a

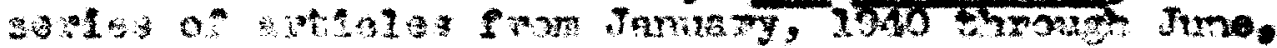
1940.

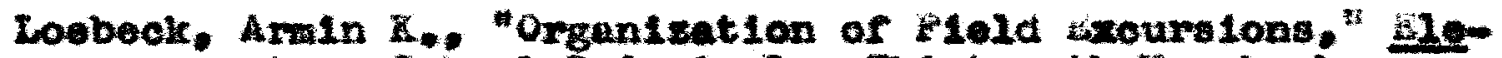

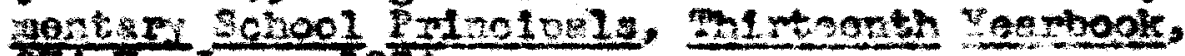
214-1, June, 1934.

Hocallum, Jeasie, "All Abona for stouratons," Elementary

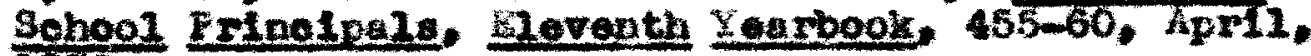
I952. 
1111er, L. Feul, "School Journoys and School Joumal1am," Glearlng House. 5:229-31, December, 1930.

Morris, Nel1e. "Trips in an Exporience Curriculum, "Chllahood Educet1on, 15:347-51, Apri1, 1939.

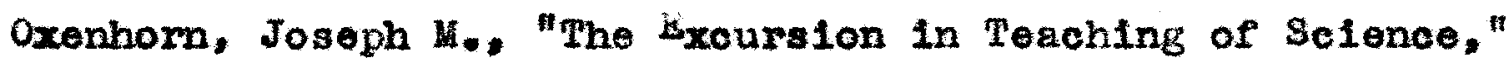
H1sh Points, 23:61-5, February, 1941.

Price, R. H** "Study of the Values of Fleld Trips" "Blomentary School Prinolpels. Thirteenth learbook. 302-5, June: 1934.

Remmlein. Madaline $\mathrm{K}$. " "Bxcursions are Often Hazardous." Nation's Schools, 27:55-6, May. 1941.

Rifo. Harvin, "Tours in Dynamie Bducation," Educational Lethod, 20:223-5. Febmary. 1941.

Rushing, Frances, "Organlzing School Excursions," The Instructor, 53:29. Fobruary, 1944.

Sohwamm, Gustave, "The Flela Trip: Bdueation by Contact," Edueationel Screen, 23:391-2, 394, November, 1944.

Shaw, Blien, E." "Visiting the Botenic Garden," Blementary School Prino1pals. Eleventh Yearbook. 476-81, AprII. 1932.

Sw1th, L. C., "Breakfast at NIne," Amerlean Chlldhood 32:7-8, Deoember, 1946 .

Spacht, Charles A, and Al11e L. Harmen, "TrIps, Bxcursions, and Lectures," Educational Method, 14:144-6. Decomber. 1934 .

Waltermire, Helen H. "Leeming Through Seelng," The Instruetor. 5:14, June, 1941 .

Weaver. David A. "Excursions in a Hetropolitan Center," Elementary Sohool Frincipels. Thirteenth Yearbook. 289-94, June, 1934.

Wnchell. Lawrenoe. "F1eld Prips Develop Communtty Interest." Education, $61: 377-70$, February, 1941.

Yoder, kl1zabeth, "Vitallzing Seventh Grede Goography Through Class Joumeys," Elementary School Princ1pals. Q1ghteenth Yea rbook, 478-80, July. 1939. 
2achart, Blizeboth. "Pleld Trit Sxpertencea in the Intarmodlate Grades." Joumal of Geokraphiv $33149-60$. Pobruary, 1834 .

State and United States Governont Docusents

Ade, Lester K.. Exrending the Glasanogg, Harrisbur, Com-

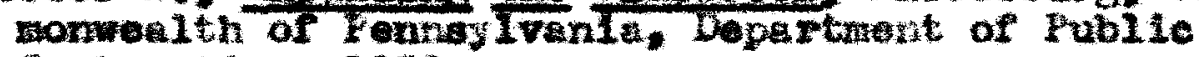
instmetion, 1930 .

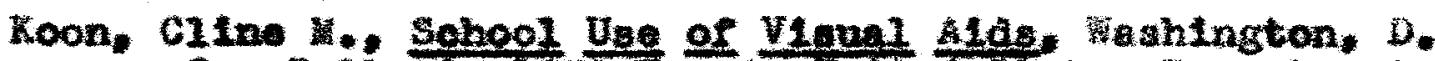
C.. Bulietin 1036 .10. 40. United States Department of Intertor, Orf lee of Bducat Ion, 1938.

Onpublined taterlais

Loulavili. Boand of Eduoution, Division of Currtouluen, and Heeeareh. "The Onlo Vailey (Hidale Statea). Dapubilahed fifth grade unit, Lovisville. 1967.

Loulsvilie Publle Schools. A Pentative Aetivity GurgleuIum in soolal Studien ror blezentam sohools

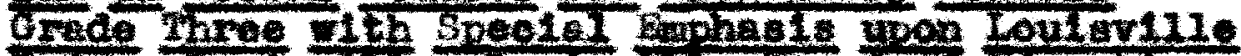

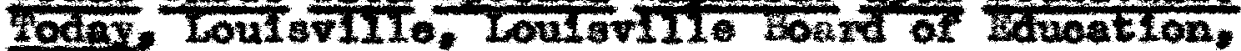
1988.

Loulswillo Publie Schoola, "DLrectory 1946-1947," Loulsville. Boan of Eavestion.

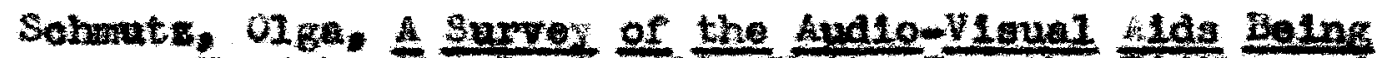

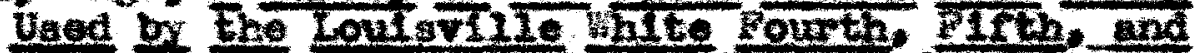

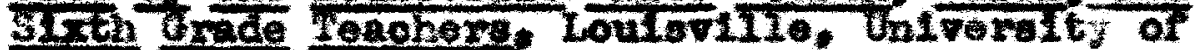
Loulsville Mater's inesis. 1942. 


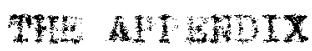


ThE AF BHDEX

Questlonnalro

1. Bave you over taken oless on an exourston for Soelal Studieat

2. Hitas your class (thia school year) been taken on an excursion?

3. was this trip teiren in conneation wth the study of The onlo Vailes - Mldale States" (a social studies unit)?

4. To what place (or ploces) was the trip wade?

5. Cheak the rollowing as to the number taking the trip: A. The ontire olases

B. Studient Cominttoe

C. Individuals

6. When was the trip taken? (Chook)

A. An introduetion to tho study

B. Daring the study of the unit

c. At the end of the unlt

D. Daring school hours

E. Arter sohool hours

F. On Saturday

7. Cheok rease for the purpese of the trip.

A. To gain definite inforzation frow diroot contact

B. To stimulate and bronden interest

c. To verify knowledge galned from other souroes

D. To develop a enttioni attitude

5. To develop keonness of obaervation

F. To help orgenise inforwation gelned

c. Other roaens

B. Gheok the activitios used in the properation for the trip.

A. Sxtensive roading

B. Diacusation

C. Froparation of guestions to anc

D. Listing things to look for and exanine

E. Colleoting plotures

. Sotting up etandards of conduct, courteay, and rasponalbility 
8. (continued)

0. Letter for permilalon to vialt

I. Toplos assigned and atudied

I. Individual pugll project planzed

J. Other ectivities

9. Plewas check the activitles used in the follow-up.

A. Wtiten reporto

B. Oral roporta

C. Dookiets for the MIbrexy

D. exthits

L. Thankmon lettere

P. Diserzestion

0. Dranatizations

I. Axt work

I. Reporta for seheol paper

J. Puppet shows
I. Radio progres

L. Oraph

语.

D. Charta

o. Diagrans

P. Howe-nute movio

Q. Lantern alldes

R. Deseription

S. Teste

T. Storlea

U. Other activities

10. Plocse cheok the reason if no trips wore made.

A. Do you object to excurations? (check the reath or reasone wy)

(x) too great responsibility

(2) too moh time involved in gotting to and from the abjective

(3) diffleuity of handilng lange froups

(4) chlldxen do not get enough boverit to juetify tive and efrort involved

(5) other roason:

B. wowla you have destrod to talke the ohildren on exouratons? (Cheok reesion or roeacne thy the trity

was not mede.)

(1) sohodule too heavy

(2) problum chllaven in clasarooa

(3) too wath work involved

(4) laek of oonvenient tranoportation

(b) other wesons

11. Please check the following aourees of information as to thelf value in prowlalng a better understanding of the untt, The onto valles."

I Duniness Diatriet

Gotione: Reculad

1. Unin Itrest (moleavio areo)

2. Fay Wertket - between prookFloyd and liberty-Jerfermon

11 Civio Batlatings

2. CIty HaIl - Sixth and Jaffexson 
II (eontinued)

2. Oustom House and Post Orflee

gottonal iemulad S1xth and Sroadway

5. Genorwi Hoepltal - ses last Cheetrut Street

4. Jefferson County Amory - Nifth and Armory Place

5. Jefferwon County Court House -Jefreraon Street betwoon Fift and Stxth Strets:

6. Loulaville Pubilo Library -Fourth and Yort Strests

7. vemorial Andtoriva - Fourth and Kentucky Streots

III Clubs and liveduss

1. Plison c1ub - Broelcenridge between Pinet and Swoond stroets

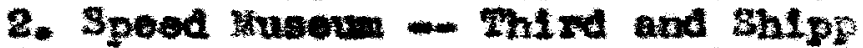

3. Fublle Library lugeu - Fourth and rort Streota

IV Induatries

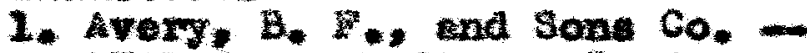
1721 Seventh Stroet hosd

2. Belland 1111 - 912 Lapt Broadway

5. Bourbon Stook Yarde - 1048 Rest Hain stroot

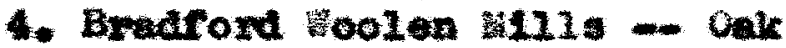
Street at Reatilinger

5. Coos Cola BottIIng Co. - 1661 veot Hill

6. Dalries

7. Ford Sotor Co. - 1400 weotern Nkw.

6. Honey I Inust Balcery - 1453 South Seventh Street

9. Lent Paglicers

10. Hengel Compary - 1121 Zane Ave.

11. Petroloum Rerinomea - west knd

12. Feynolde Letala Co. - 2000 South inth Stroot

- Statues and ${ }_{\text {Fonuments }}$

1. Custlemun Wonuzent - Cheroksoe Hd, and Oherolke Perteway

2. Confederate tomuent -- Third and Shipp Streete

3. Daniel Boone Sonument -- Cherokes Park 
y (eontinned)

4. Clark's grove in Care Hill

Optional Recutred Cemotery

5. Jef fervon Wonument - Pront of Court House, Pifth and Jefferwon

6. Looust Orove (C1erk's last home) Bianicenbaker Lene

7. Gulbers H111 - Moargras Creok near fovlar Lovel Rosd (Cleric'o father': howe)

B. Statue or Henry Clay - in Fotunde or Count House, Fifth and Jerfaraon

9. Statue of Abrahsn ifnooln - In front of ${ }^{2}$ in Publio Librery Fourth and York Stroets

10. S1te of old Fort Felson Seventh and in stroots

11. Froslaent Zeohary Taylor"s flome and 策onvent - By way of Brownsboro Rd. and Blankenbaker Lane

12. FeIntings at Seelbach Hotel -

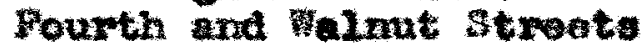

13. Haricer on Court Roues - honow ing C1ant:

y. Trensportation and Corasintention

1. Bownan Flela Alrport - Taylorsvilie Ron

2. Brunch Telephone orfloe

3. Coupler-Journel and Louleville

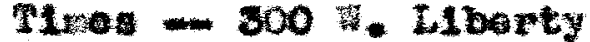

4. Rall ros 3tation

A. Union 3tation - Jonth and 3rosaway

B. Central Depot - Seventh and Miver.

5. Hallmod Yards

6. Truek Doyots

7. Radio Stations

8. Oroghound Bus Station - F1fth and Brondway

VII

A. The vater Front - on the Ohio itvor

B. The U. S. Cosst Guard Station Thind and alver 
VII (oont inued)

c. Loulavilie and portiand Canal

gptional lenulned Foot of Trenty-Beventh st.

D. Hydrombeetrio Plant - Swontyaxth end Canal

VIII Souroo of Loussville 籍ater Suyply

A. Rivor lowd Fuming station

B. The Reservolr - Frenkrort Ave.

C. Croscent Hill Fumplng station

Prankfort Averue

IX HLodlaneous

A. U. 3. Fislery - Glbson Lane

B. "The old Ientueky Hoss" Kantuoky State Falrgnounda

c. Southom Eaptist Theologion Serinary Susenw - Grinstead Drive and Lexington houd

12. Can you augset any othex place in Loulsvilie to viatt that ia not inoluded in the above 11 at and that wowl be bonerielal in the teaching of tio soctal studiea unt. "he onto Valley?"

13. Would detalled liat las bovel, of avallablo sourees of Informetion in loulavilie to viat, be holprul and bescerteluz in the totel Ine of soclal atudiea in the fifth grade? If no, how?

14. Suztestions or Remazk:

Name

Sehool 


\section{Tebulation of euestionnalre}

Flatse oheok the following soures of inforetion to their value in providing better underatandins of the unlt, "The onlo villoy."

1 Bualneas District

$$
\text { Actual No. }
$$

lereant

1. Hain streot

2. Hay rarket
35

25

II Oivio

1. City finil

2. Custom House and Post orfico

3. GenersI Fosp1tid

4. Jaf Serson Counts Antory

5. Jeffersen Count

Court House 18

6. Loulavilie public Library

7. wa

30

20

22

45

40

20

16

18

20

1. Filion club

2. Sperea rusew

3. Fub1se Lsbray 端useun

10

20

78

56

22

44

25

44

58

23

48

100

5

89

27

40

25

4

25

67

III CIubs enc shoevens

IV Induetries

1. Avary, B. F. and Soma co.

22

2. Ha11m rd $411 \mathrm{~s}$

20

3. Bourbon stodit Yarda

10

4. Bradford toolon 站11:

5. Coeo Cola Bottline company

10

20

20

6. Delmies

10

7. Fond Hotor Co.

9. Boney rust Beizeryi7

10. Mengel Cowpany 20

11. Fetroloum Refinories

22

12. Reynolds Hetals 27 Companz

27

30

25

40

38

44

60

67

56
12

60

56

s3

51

0 0 
$\checkmark$ 3tatues and Momiments

1. Caatlean vonuwent

2. Gonfoderte tonvent

3. Danlel zoone ksonwent

4. CI ark' grave

Lotwal Ho ptional required

Pereent

5. Jaffersen tonument 13

32

14

69

31

33

12

73

27

6. Looust arove

27

18

19

27

25

7. Huxborry thlil

20

6. Fenry ciey statue 18

18

27

- Abruham Lincoln

Statuo

20

25

10. Port Helson site 20

25

60

40

11. praidont zachnry Fay Ior's Howe-lionument

26

19

58

40

44

60

10

48

60

paintinge at Seelbrat llotal

33

12

the

44

56

40

variser on Court

House

18

27

60

56

56

$\checkmark I$ Trensportation and

Cowerumlostion

1. Bowman Pleld AIrport

22

78

2. Branoh Telephone orrice

26

42

58

3. Courter-Jonme1 ard Loulaville plmea 16

29

4. Mall roed Stations 20

25

5. Finl1noud vaxda

16

6. Truch Depots

27

28

7. Radio Statlon:

19

8. Oreyhound Bus Sta. 29

17

26

16

36

44

60

68

42

64

64

56

40

33

58

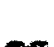

44

56

B. The V. 3. Const Graxa

20

25

44

56

c. Loulsville and Fortiand Cantil

32

33

27

73

D. Pydro-

18

27

40

60 
VIII Source of Louls-

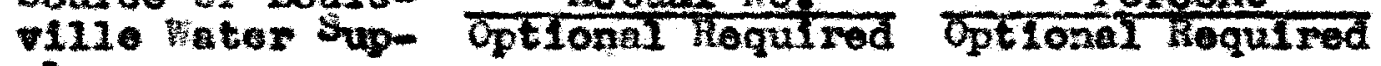
clis

4. Itiver Road Fump-

Irve station

B. The Reservolr

C. Crescent $211 \mathrm{I}$

20

18

85

so

$4 \mathrm{C}$

Fumping Station

20

25

44

56

IX Lcellaneous

k. J. S. Fiahery

31

14

60

$\mathbf{3 1}$

B. "Tho old Kentucky Southern Baptist

25

20

56

44 Theolocteal SemInaxy

24

22

53

47 
westions Jsed in Interviowing the PIfth aradn foechers 1. What twips have you wade in comootion with the wit,

2. How many puylls took tre trip?

A. The ontire clase

B. Student com it tee Hoy wany?

C. Individunis

3. When wa the trip tatien?

A. As an introduction to tho unit

B. Daring the study of the unit

C. At the ond of the unt

D. Durling sohool hours

E. Arter solioal hours

F. On Saturday

4. Whet tho purpose of the trip?

A. To geln addutional information

3. To stivulate discusalon

c. Fo develon keenness of observetion

D. To Increase voluntar, rouding

E. To lead to ruyther setivities

F. To 11 lustrate facts alrsady known

c. To solve probleus previouely presentad

H. To ald in intergreting statiatienl inforsation

I. To develor desirable stitudas

J. To doveloy an apprecletion of sonething

r. to answer apeetfio quostion

L. To Introduce unit or subjoct

瑟. To ourinartse of rovlev

2. To cievelop a proceas

0. To present abatract subject matter in a conerete way

F. other rocsors

5. Thet was tons in proparation for the tmip?

A. Tow was the pugll interest in the trip aroused?

B. What tratorlals wore used to develop a background of knowledze ebout the plae visited

c. hat proparator cetivitios did tre ehlidren ongage $\ln$ ?

(1) Collecting pletures

(2) Settine up atandarde - conduet, courtsay, and responslbility

(3) Iisting things to look for and excerino

(4) Dilacusaion

(5) Proparation of questiona to esk

(6) Lottora for persiasion to visit 
5. (oontimed)

(7) Extexaive readins

(8) Indiviaun pupil projocts

(9) Toplos assigned and atudied

(10) Other activitios

6. The Excursion

A. Wat activities ald the excursion itsolf inelude?

B. Wat type of instruction wes given wille at tiso place vialted?

(I) Ixplanation by guldo

(2) Sxplanation by the tedcher

(8) An printed gulde sheet of thines to bo noted

(4) Puplis to note anything

(s) other tryes

c. How wach time was apent on the trigt

D. Whst wasis of transportstion was usea?

E. That ldeas and tortals did the puplls obtaln for class 100 uge?

F. What probless were involved in anking the trip?

7. Bveluation of the trip

A. Whet pero some of tite pupils" resetlons as a result of the oxcursion?

B. As rogult or the trip ald you notios on the part of your class, a definite growth in attitudes, intorest. sta general worale? ixurplos.

c. Did the trip heip la tho teaching of the unit? Sxplatin.

D. Livo jou any conerete ovidence that the excurston you have al reotod has boen vertituhile?

(1) Inoroase knowlodge lndiocted frow tost roaults

(2) Individual projecta carried out

(5) Hore bocks road

(4) Wore Intereat in class Alseasaton ard cally work

(s) Individual puplis take additional exenxelone

(6) Other ways

B. Whezo were some of the follow-up activities?

A. Wirition reports

B. Oral reporta

C. Bocklets for the Mlbrw

D. Sxhibitis

S. Thank you lotters

F. Discussion

0. Dratertzations

耤. Ant work 
8. (continued)

I. Noports for sohool paper

J. Fupet ahows

K. Radio prograns

L. DLagruis

* Charta

. Oraphs

0. Home nade novles

F. Lesztem slines

hawe

Sohool

Grade

PIvo yeare teaching oxpertenoo. 


\section{Elstorie Spots in Loutsville Pertating} to this Dnit 1

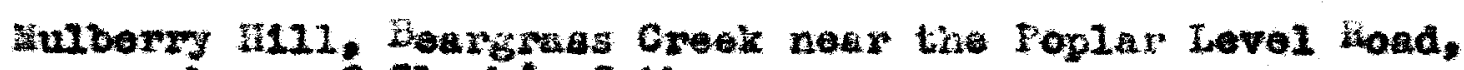
hore of clark's father.

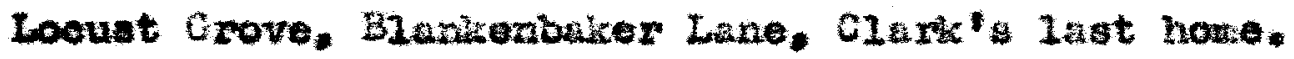

clark's Exwe in Cave H112 cemetry.

C2. maxis in the Seolbach Fotol.

Fort kezson Fomwent at the corner of Worth Seventh Jtrest and lest un in stroet.

Statue of Denlel Boone in Cheroked rark.

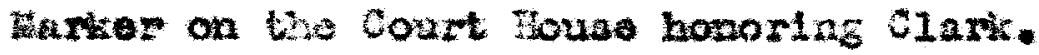

\footnotetext{
"the Onlo Valleg (fildale states)" p. 16.
} 
A Bamplo Iravel I.Let

Pleld Trip Record

Class

Teacher

Date

Dostination

Fransportat1or Usoc

TIme Seave School

4nyo Dostination

mine Leave Destintion Amative st sohool

Comsents

Studente At tending

1. 3 .

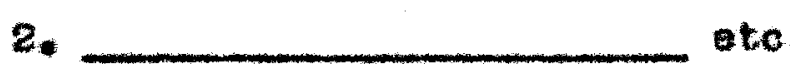

Studants wot Attenane

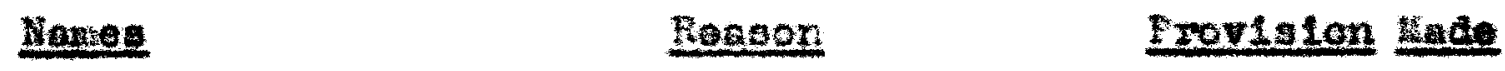

1.

2.

oto.

\footnotetext{
T

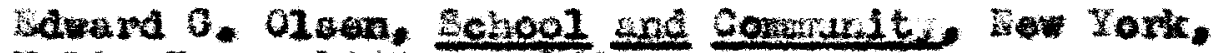
Prontice-14al1, Ine., $1240, \frac{1}{160}$. 
A Sample of lenaliaton of a karcut for a trip

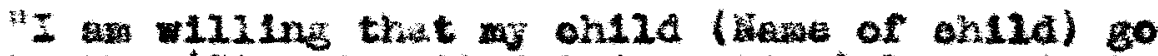
to the (Give detalled Intormation) loeated t (Givo looation) on (Date). I heroby welease the Boaxd of Equeation of (Blank tom). the

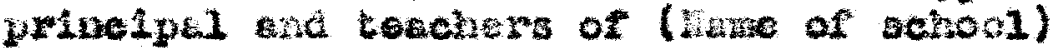
rxom sry and uil rosponsibility for any aceldent wich was ocur et (Destination) or en route to or frow that place."

\section{1 gratumo}

1 Daniel $\mathrm{n}$, Hodydon, "Ilubility and the Sehool Trip." Clearine House, 17:434, warch-kpt1, 1963. 
Samplo form of a Ferent inatvor

"Berore chllamen sro tatan from the sehool pounds, it 13 ossantial thet the parents bo notiried and that thoy givo conowt. The following form has boon uned in the Incoln Consolidatad school." 1

Dear Fatizon:

The ohlidren of fur achocl can be helpod in tholr

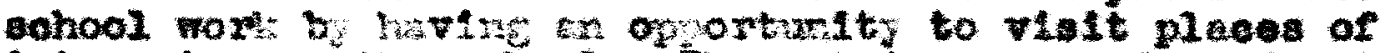
interest net the achool. These tras are made under the

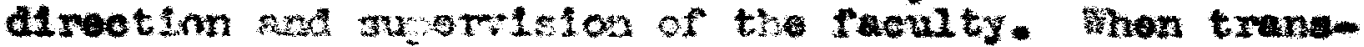
portation is necossary, all posalble ow and protoction is traken.

It is destmble that the varents know about these trips und givo perriszion for trialr ahild to take advantage of the sare.

vialt the

on arto is planned to to WII be ir charee of the group.

TSIgnatu of Supervisor In charge)

About a wook before the trip, the top was rilled and sent to parents. The lower part rilled by parate and roturned to school.

\section{Parant reralasion}

I desiro to have papIT nome go 1 th the group on this trip. It is understood that the axpruisor in ohurge of the grour as well as the transportetion depertere will not assue responstbility for aecldents or happening over which the have no control.

\section{(Parente sI Enature)}

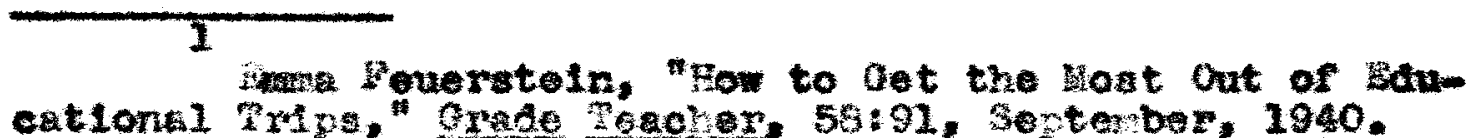

